\title{
«EN FAVOR DE LAS VÍCTIMAS DE LA GUERRA»*1
}

\author{
POR \\ CRistóbal Robles MuÑoz \\ Instituto de Historia. Centro de Ciencias Humanas y Sociales, CSIC, Madrid
}

\begin{abstract}
RESUMEN
La representación oficiosa dada al cardenal Gomá en diciembre de 1936, el envío Ildebrando Antoniutti como delegado apostólico en julio en misión humanitaria, mantuvieron bajo mínimos las relaciones de la Santa Sede con el Gobierno de Franco. La situación no cambió en 1937. El nuncio Gaetano Cicognani no llegó hasta junio de 1938. Los pasos discretos de una diplomacia secreta aconsejaron en septiembre de 1937 formalizar las relaciones, en su nivel más bajo. Antoniutti y Pablo de Churruca fueron nombrados encargados de negocios, en Burgos y ante la Santa Sede. La carta colectiva de los obispos ayudó a mejorar la imagen los nacionales ante los católicos de otros países. La posición doctrinal en que se insertan estos hechos quedó fijada en las tres encíclicas publicadas en marzo de 1937. En ella se denuncia la persecución religiosa del
\end{abstract}

\footnotetext{
* Este trabajo se ha hecho en el marco del proyecto de investigación HAR2008-01002: «España y la Santa Sede en la Europa de entreguerras. Una perspectiva comparada (1930-1939)», Ministerio de Ciencia e Innovación. Secretaría de Estado de Universidades.

SIGLAS

$A G$ : volumen y páginas Archivo Gomá. Documentos de la Guerra Civil, edición de José AndrésGallego y Antón M. Pazos, Madrid, CSIC.

ASV Affari.Ecclesiatici país, período posición fascículo y folio: Archivio Segreto Vaticano

ASV Nunz.Madrid caja y folios, Archivio Segreto Vaticano Nunzitura di Madrid

ASV Segr.Stato rubrica año fascículo y folios: Archivio Segreto Vaticano Segretaria di Stato

${ }^{1}$ Recibió Franco en Salamanca a Ildebrando Antoniutti, delegado apostólico. La Santa Sede había entendido el significado de los sucesos españoles. Antoniutti destacó la atención con que el Papa los había seguido. Por eso «mi inviava appunto per occuparmi, a nome suo, del retorno di tanti poveri bambini baschi che vivono all'estero, e per cooperare in altre iniziative caritatevoli in favore delle victime della guerra». Antoniutti-cardenal Pacelli, Salamanca 1 agosto 1937, ASV Nunz.Madrid 968 528-529, editado en Vicente CÁrCEL OrTí, «La nunciatura de Madrid y la embajada de España en el Vaticano (1931-1939), Archivum Historiae Pontificiae 44 (2006) 322-324.
} 
comunismo, el temor al nazismo y el deseo de salir de la persecución personando y luchando por la justicia a favor de las clases populares.

PAlabras ClaVE: Santa Sede Pío XI Isidro Gomá, cardenal Pacelli, Antoniutti, guerra civil, represalias, nacionalistas vascos niños vascos expatriados

\title{
«FOR THE VICTIMS OF WAR»
}

\begin{abstract}
Informal representation given to Cardinal Gomá in December 1936, sending Ildebrando Antoniutti as apostolic delegate in humanitarian mission in July, remained at its lowest level relations between the Holy See with the government of Franco. The situation changed in 1937. The nuncio Gaetano Cicognani did not arrive until June 1938. Discrete steps of a secret diplomacy advised in September 1937 to formalize the relationship, at its lowest. Antoniutti and Pablo de Churruca were named Responsible of Affairs, in Burgos, and to the Holy See, in a respective way. The collective letter of the bishops helped to improve the image of «national» Spain before the Catholics in other countries. The doctrinal position in which these facts were inserted was fixed at three encyclicals published in March 1937. They condemned the religious persecution of communism, nazism and the fear of a desire to runaway of the persecution forgiving people and fighting for justice for the working classes.
\end{abstract}

KEY WORDS: Holy See, Isidro Gomá Pius XI, Cardinal Pacelli, Antoniutti, civil war, reprisals, Basque nationalist, Basques expatriate children

Recibido/Received 12-01-2009

Aceptado/Accepted 23-04-2009

Hablando en Roma sobre sus dos obras más recientes ${ }^{2}$, Vicente Cárcel insistió el 26 de mayo del 2009 en la labor humanitaria de la Santa Sede y de los obispos españoles durante la guerra civil y después de ella ${ }^{3}$. Acogieron a los prófugos. $\mathrm{Se}$ interesaron por el intercambio de rehenes. Favorecieron el regreso de los niños vascos expatriados. Intervinieron para salvar la vida de quienes pedían su y

\footnotetext{
${ }^{2}$ Caídos, víctimas y mártires. La Iglesia y la hecatombe de 1936, Madrid, Espasa Calpe 2008, y Pío XI entre la República y Franco, Madrid, Biblioteca de Autores Cristianos, 2009.

${ }^{3}$ Uno de los objetivos de la misión caritativa de Ildebrando Antoniutti fue «tenere a freno colla sua presenza i falangisti da parte dei quali si temevano sanguinosi eccessi, come purtroppo era accaduto a Badajoz, Málaga ed altrove, contro la popolazione di Bilbao, non appena le truppe italiane che l'avevano occupata, se fossero ritirate da quella città». Istruzioni per Sua Eccelenza Rev.ma Mons Gaetano Cicognani Arcivescovo Titolare di Ancira Nunzio Apostolico presso il Governo Nazionale di Salamanca (Spagna) 10 junio 1938, original mecanografiado en Arch.Nunz.Madrid 1965 II 35-79. texto en Vicente CÁRCEl ORTí, «Instrucciones al nuncio Gaetano Cicognani en 1938», Revista Española de Derecho Canónico 63 (2006) 207 y 211.
}

Hispania Sacra, LXI

124, julio-diciembre 2009, 691-753, ISSN: 0018-215-X 
denunciaron la represalias ${ }^{4}$. La documentación del Archivo Vaticano, abierta hasta febrero de 1939 deja constancia de esta labor humanitaria. Cárcel cree que esa labor prosiguió con Pío XII, como podrá verse cuando se consulte la documentación aún embargada 5 .

Este trabajo forma parte de un proyecto sobre la Santa Sede y la II República. El Vaticano trazó la orientación que guió la conducta de la Iglesia en España estos años. Su inspiración era una apuesta por la libertad de los católicos y su deber de respetar los poderes constituidos, en aras del bien común. El relato de lo que sucedió entre 1931 y 1939 muestra que era una opción audaz y que el camino elegido tendría dos serios obstáculos. Un sector de la Iglesia prefería la protección a la libertad. Un sector de los republicanos apostaba por una revolución, es decir, por colonizar la sociedad y guiarla según un modelo, indiscutible, porque, frente a lo anterior caduco, tenía el valor de su vigor. A pocos meses de iniciarse la guerra civil, la Iglesia en España apostaba por «hacer el bien». Lo dijo ante los obispos católicos de todo el mundo en julio de 1937. Comenzó a hacer el bien, porque nada puede liberar del deber de perdonar, de proteger, de ayudar. Como dice un viejo texto cristiano: no hay noche para el amor al prójimo ${ }^{6}$.

Según lo iprevisto en el proyecto, utilizamos la documentación editada y remitimos, cuando es necesario, a la documentación vaticana inédita hasta septiembre del 2006.

\section{LA APUESTA POR LA PAZ CON LOS VASCOS}

Respondiendo a su discurso del 22 de diciembre de 1936, el cardenal Gomá escribió el 10 de enero de 1937 su carta abierta José Antonio Aguirre respon-

\footnotetext{
${ }^{4}$ El 1 de febrero de 1937 Giuseppe Pizzardo escribe el cardenal Gomá para que no sean represaliados dos diplomáticos destinado en la embajada ante la Santa Sede. No se habían adherido al movimiento nacional. La respuesta, 22 febrero y 2 marzo, $A G 3,14-15$ y 286-287 y $A G 4,20-21$. Esos mismos días hubo una gestión para salvar la vida de Manuel Carrasco y Formiguera. El cardenal Gomá no pudo hacer nada entonces, porque no fue condenado a muerte hasta el 28 de agosto. Fue ejecutado el 9 de abril de 1938. Pacelli-Gomá, 15 marzo 1937 y respuesta, 18 marzo, ibidem 4, 217-218 y 249-250. Vid. Alfonso BotTI, «La liberación de Manuel Carrasco i Formiguera a través de la correspondencia entre Alfredo Mendizábal y don Luigi Sturzo (1937-1938)», Ciudad de los hombres, ciudad de Dios: homenaje a Alfonso Álvarez Bolado, S.J, Xavier Quinzà Lleó y José J. Alemany (coords.), Madrid, Universidad Pontificia de Comillas, Servicio de Publicaciones, 1999, 499-514.

${ }^{5}$ Entrevista con Inmaculada Álvarez, «La Santa Sede y los obispos españoles salvaron miles de vidas republicanas tras la guerra civil», Zenit.org, 26 mayo 2009.

6 «Que ni siquiera la noche interrumpa tus quehaceres de misericordia. No digas: Vuelve, que mañana te ayudaré. Que nada se interponga entre tu propósito y su realización. Porque las obras de caridad son las únicas que no admiten demora...». De los sermones de San Gregorio Nazianceno (328389), sermón 14. Fue obispo de Sácimo en la Capadocia, y, por algún tiempo, de Bizancio.
} 
diendo a su discurso del 22 de diciembre. La Iglesia apostaba por la paz, aun sabiendo que había aspiraciones justas y reclamaciones atendibles en quienes combatían al lado de los que la perseguían ${ }^{7}$. El 30 de enero, el cardenal Gomá publicó «La Cuaresma de España», una carta pastoral sobre el sentido cristiano-español de la guerra para orientar a sus diocesanos. En el horizonte de la esperanza cristiana, la paz. En la profecía del Reino de Dios, la paz, obra de justicia. En el saludo de Jesús resucitado a los suyos, la paz. En la plegaria sobre las tumbas y en la memoria de los muertos, «requiescat in pace». Sobre las tumbas de quienes mueren en la esperanza de la resurrección, pax $^{8}$.

Silvio Sericano, encargado de negocios en Madrid, desde la salida del pronuncio, Federico Tedeschini, redactó el 11 de enero un informe sobre lo sucedido en la capital de la República desde el 18 de julio al 3 de noviembre, fecha en la fue evacuado a Francia en un avión francés.

En la tarde del 18 de julio, el director de El Debate envió un redactor a la nunciatura para decirle que se refugiara en una embajada, descartando las de Alemania Italia y Portugal, porque podrían ser asaltadas. Decidió seguir en su puesto. La noche del 18 salió de Madrid su obispo, Leopoldo Eijo y Garay.

El 19, armadas sus milicias, socialistas y comunistas sembraron el terror por las calles. Por la tarde se inició la quema de templos. En la mañana del 20 temió que incendiasen la nunciatura. Ardió el día anterior la cercana parroquia de San Andrés. La toma del Cuartel de Montaña fue un hecho sangriento. Lo bombardearon aviones leales a la República.

En esos primeros días, 20 iglesias incendiadas, incluida San isidro, y todas las demás saqueadas. Se buscaba a sacerdotes, religiosos y religiosas a los que se creían en posesión de dinero, para saquearlos. Muchos sacerdotes fueron

\footnotetext{
7 «Señor Aguirre: yo le invito en el nombre de todos estos amores, que usted tiene, como buen vasco, arraigados en su corazón; por la caridad de Dios, que quiere que todos seamos una cosa con El, a que, como padre y rector de ese pueblo, busque coincidencias y excogite medios y halle una fórmula eficaz y suave de devolver a su pueblo la paz perdida. Cuando no se lograra más, se tendría el mayor bien que pueden apetecer los pueblos, porque es el fundamento y corona de todo bien. ¿Quién sabe si con la paz, y a más de ella, se podrían lograr anhelos legítimos de ese noble pueblo!». La edición original, Cardenal Isidro Gomá y TomÁs, Respuesta obligada: carta abierta al Sr. D. José Antonio Aguirre por el Emmo. Sr. Dr. D. Isidro Gomá Tomás, cardenal Arzobispo de Toledo, Pamplona, Gráficas Bescansa,1937, 16. Puede consultarse en http://www.gipuzkoakultura.net/euskera/ediciones/atzo/1937/index.htm.

Felicitaciones al cardenal por este escrito, pueden verse en $A G$ 1, 176. La carta abierta fue corregida por la censura. Luis Antonio Bolín-Luis María de Despujol, Salamanca 17 enero 1937, ibidem 199200.

${ }^{8}$ Tuvo amplia difusión. El cardenal Gomá la envió al cardenal Pacelli el 5 de febrero. El texto puede consultarse como anexo a esta carta, AG 3, 82-105. Vid Fernando de MEER, «Una carta de José Antonio Aguirre al cardenal Gomá (9 de marzo de 1937). Nota documental», Boletín de la Real Academia de la Historia, 184/3 (1987) 521-562.
}

Hispania Sacra, LXI

124, julio-diciembre 2009, 691-753, ISSN: 0018-215-X 
asesinados. Los demás estaban dispersos y ocultos. El 21 de julio presentó una nota de protesta ante Augusto Barcia, ministro de Estado. No hubo respuesta oficial $^{9}$.

Comenzaron luego los asesinatos de civiles. La acción de las milicias sindicales y de los dos partidos obreros parecía buscar solo el botín. Los registros se hacían calle por calle y casa a casa. La mayoría de los detenidos fueron asesinados en la Casa de Campo o en los cementerios de la ciudad. Cuando salió de Madrid el 5 de noviembre había unos 2000 presos políticos. Toda la riqueza pública y privada pasó a las organizaciones rojas. El Gobierno era incapaz de controlar la situación. Hubo matanzas colectivas de presos bajo su custodia ${ }^{10}$. Estas iniquidades en la zona republicana agravaban el comportamiento de los vascos. Era intolerable.

Uno de los asuntos más delicados fue el derecho de asilo ${ }^{11}$. A comienzos de noviembre había unos 2000 protegidos por las legaciones extranjeras en Madrid Los pasos dados por el cuerpo diplomático para humanizar la guerra fueron inútiles. Los condenados eran ejecutados inmediatamente. Los otros, eran puestos en la calle de noche, mientras había «estado de sitio». Caían en manos de las milicias que los asesinaban en el acto ${ }^{12}$.

En la zona nacional se puso en marcha en 1937 la reorganización eclesiástica. Empezaron a tomarse las medidas más urgentes. Una de ellas, el restablecimiento de capellanes militares ${ }^{13}$. El clero debía mantener la disciplina y seguir vinculado a los obispos. No convenía que apareciera ligado a las milicias de los

${ }^{9}$ Los antecedentes de estos atentados contra los templos y otros edificios de la Iglesia, entre febrero y junio, han sido editados. Vicente CÁrCEL OrTí, «Documentos del Pontificado de Pío XI sobre España», Analecta Sacra Tarraconensia 80 (2007) documentos 4 y 5 del anexo, 341-409. José Ramón HeRnández FigueIREdo, Destrucción del patrimonio religioso en la República (1931-1936), Madrid, Biblioteca de Autores Cristianos, 2009, 192-340

${ }^{10}$ El 12 de agosto de de 1936 fue detenido en la estación de Santa Catalina, en las afueras de Madrid, un tren que trasladaba presos desde Jaén. Fueron asesinados sin que las fuerzas que custodiaban la expedición, las autoridades penitenciarias ni el Gobierno los protegieran. Vid. Antonio RuIZ SÁNCHEZ, Monseñor Manuel Basulto Jiménez y compañeros. ejemplaridad de vida y martirio, Córdoba, CajaSur Publicaciones, 2001, 339-346. Hubo más casos como este.

${ }^{11}$ Sobre el ejemplar comportamiento de la embajada de Chile, en España a través de los informes diplomáticos chilenos:1929-1939, selección, introducción y notas de Juan Eduardo Vargas, Juan Ricardo Couyoumdjian y Carmen Gloria Duhart, Santiago y Madrid Ministerio de Relaciones Exteriores de Chile, Consejo Superior de Investigaciones Científicas,1994, 185-420. Antonio Manuel Moral RoNCAL, Diplomacia, humanitarismo y espionaje en la guerra civil española, Madrid, Biblioteca Nueva, 2008, 69-202 y 569-582.

$12 \mathrm{El}$ informe terminaba contando los detalles de su salida de Madrid. Silvio Sericano-Pacelli, 10 enero 1937, ASV Affari.Ecclesiastici Spagna IV 889, 265, 63-83.

13 Gomá-Pacelli, Pamplona 24 octubre 1936, y ASV Affari.Ecclesiastici Spagna IV 891, 270, 29 30. AG 1, 245-252 y Gomá-Pacelli, 3 enero 1937 y Pacelli-Gomá, 9 de enero, AG 2, 37-39 y 83-84. 
partidos que luchaban en el frente ni a la administración que estaba creándose en la zona nacional.

En una entrevista del cardenal Gomá con Giuseppe Pizzardo se habló de algunas cosas urgentes. Entre ellas, del clero nacionalista vasco, de su permanencia en la diócesis de Vitoria o de su traslado a Castilla ${ }^{14}$. Javier Lauzurica, obispo auxiliar de Valencia, fue administrador apostólico de Vitoria. Se acusaba entonces al obispo de Oviedo, Justo Echeguren de ser nacionalista ${ }^{15}$.

Se puso en marcha una oficina para atención espiritual al ejército. Al frente, un sacerdote castrense, con jubilación reconocida, para evitar gastos. Podrían ser enviados sacerdotes de una diócesis a otra más necesitada, con permiso del obispo y cuidando que no se concentren en los lugares mejores, como Madrid.

Las órdenes religiosas proporcionarán buenos sacerdotes para la cura de almas $^{16}$. Se otorgaban facultades para sanar los matrimonios contraídos sin presencia del sacerdote ${ }^{17}$. El cardenal Gomá estaba autorizado para negociar con el Gobierno el restablecimiento de los privilegios e inmunidades de la Iglesia. Para rectificar los defectos en la pastoral y en la Acción Católica, debería ponerse de acuerdo con los otros metropolitanos ${ }^{18}$.

La alianza de los nacionalistas vascos con la izquierda republicana, su solidaridad con el Gobierno de Madrid, el peso que ese hecho tenía en la opinión de otras naciones europeas, obligaron al Gobierno de Franco pedir a la Santa Sede que desautorizara al de José Antonio Aguirre. La primera reacción fue pedir contrapartidas. Sin ellas, la Santa Sede nada podía ofrecer a cambio, si los

${ }^{14}$ Sobre este asunto, los puntos 3 y 4 del informe sobre la entrevista del cardenal Gomá con Franco el 29 de diciembre, Gomá- Pacelli, Pamplona 1 enero 1937, AG 2,13-17. En una segunda carta analizaba la situación de los nacionalistas «que luchan la lado de los rojos», Los designa Gomá como «ejércitos vasco-marxistas», ibidem 19-20. Parece que el vicario general de Vitoria, Antonio María Pérez Ormazábal, envió una carta a Franco, el 27 de noviembre. Se quejaba del trato de las nuevas autoridades al clero diocesano. Muchos sacerdotes eran tachados de nacionalistas, a pesar de que «DESDE EL 19 DE JULIO SE HA PUESTO DECIDIDAMENTE DE PARTE DEL MOVIMIENTO SALVADOR DE ESPAÑA Y HA CONDENADO EL CRIMINAL CONTUBERNIO DEL NACIONALISMO CON LAS HORDAS MARXISTAS, ROMPIENDO DEFINITIVAMENTE TODA RELACIÓN CON DICHO PARTIDO», el PNV, $A G$ 1,365-367. Sobre su visita a Luis Valdés, gobernador general el 1 de diciembre, vid su informe al cardenal Gomá, 2 diciembre, ibidem 378-379.

${ }^{15}$ El obispo se defendió en una carta a Tedeschini, 1 diciembre 1936, copia en $A G$ 1,373-387.

${ }^{16}$ El informe de la Congregación de Religiosos, La Puma-Pacelli, 20 enero 1937, ASV Affari.Ecclesiastici Spagna IV 891, 270, 36-37. Se eligió como procedimiento delegar la facultad en el cardenal primado. La Puma-Isidro Gomá, 28 enero, ibidem 40-42

${ }^{17}$ Las facultades de la Congregación de Sacramentos, Jorio-cardenal Pacelli, 15 enero 1937 y, la respuesta de Isidro Gomá, 5 febrero, ibidem 47-51 y 54.

${ }_{18}$ Documento sin fecha, ASV Affari.Ecclesiastici Spagna IV 891, 270 25. Posiblemente todos esos puntos fueron estudiado en una sesión de la Congregación degli Affari.Ecclesiastici. Los encontramos recogido en un texto impreso de $13 \mathrm{pp}$, ibidem 55-59.

Hispania Sacra, LXI

124, julio-diciembre 2009, 691-753, ISSN: 0018-215-X 
nacionalistas dejaban a sus aliados. ¿Qué quiere conceder Franco? ¿Por qué no negocia directamente? Se necesitaba una oferta formal, entregada a la Santa Sede por una persona autorizada. El 30 de diciembre el Vaticano nada sabía. Parecía que el Gobierno de Burgos exigiría la rendición incondicional. Era una prueba de su escaso tacto político. Italia sugirió que un enviado de la Santa Sede mediara entre las dos partes.

No era posible una condena formal de los nacionalistas. Medió Italia con el Gobierno de Aguirre. La Santa Sede buscaba que emisarios italianos trataran de convencerle. ¿Con qué argumentos? Fue un error que, al iniciarse la guerra, los «blancos» nada hubieran garantizado a los nacionalistas vascos, que se hubieran unido a ellos. Al contrario, habían expulsado al obispo Mateo Múgica y fusilado a once sacerdotes «inocentes».

El 26 de diciembre se pidió al cardenal Gomá una nueva gestión. Se pensó enviar una persona, no como negociador sino como «Padre» o «Predicador» que hiciera ver a los nacionalistas lo que estaba en juego, la conveniencia de que no se mantuvieran en sus posiciones y cedieran, y les insinuara la posibilidad de ser excomulgados. El 29 de diciembre 1936, el marqués de Magaz dejó al cardenal Pacelli un telegrama. Pedía una respuesta urgente el 7 de enero. El secretario de Estado dijo que la estaban estudiando. El 24 de enero había respuesta: El cardenal Gomá había estado con Franco, que se negó a conceder autonomía a los vascos. Magaz confirmó que la posición de Franco era firme.

El cardenal Gomá transmitió el 26 de diciembre al cardenal Eustaquio Ilundain el afecto de Pío XI. Se sinceraba con él: esperaba mayor acogida de la causa nacional en el Vaticano. No era así debido ¡la «obra tenaz de desprestigio», hecha por católicos y hasta «por sacerdotes, malos españoles». Tenía eco esa «labor de perturbación espiritual» en Italia, Inglaterra y Francia. Quiso salir a su paso con «El Caso de España»19. Lo dedicó a la Diputación Foral de Navarra, cuyo escudo aparece en la edición ${ }^{20}$.

19 Se trata de una «Instrucción a sus diocesanos y respuesta a unas consultas sobre la guerra actual». Iba a publicarse en el Boletín Eclesiástico de Toledo, pero se hizo una edición en Pamplona, Gráficas Bescansa, 1936. Está fechada la instrucción el 23 de noviembre. El texto aparece como anexo a una carta Isidro Gomá-Gregorio Modrego, 3 enero 1937, AG 2, 43-56.

Puede consultarse en http://www.filosofia.org/aut/001/1936goma.htm

20 «El verdadero Caso de España sería este: Que dentro de la unidad, intangible y recia, de la gran Patria, se pudieran conservar las características regionales, no para acentuar hechos diferenciales, siempre muy relativos ante la sustantividad del hecho secular que nos plasmó en la unidad política e histórica de España, sino para estrechar, con la aportación del esfuerzo de todos, unos vínculos que nacen de las profundidades del alma de los pueblos íberos y que nos impone el contorno de nuestra tierra y el suave cobijo de nuestro cielo incomparable. Así los rasgos físicos y psicológicos distintivos de los hijos traducen mejor la unidad fecunda de los padres. Y así sería España, una de substancia y rica de matices, si se copiaran, de arriba y de abajo, los ejemplos de esta Navarra, tan española y tan "ella"», Pamplona 8 diciembre 1936. 
Quería comentarle la posibilidad de que el episcopado español dirigiese al mundo «un documento autorizado». Para el cardenal Eustaquio Ilundain, eso «serviría a los enemigos de ocasión para vilipendiar y para insistir en malignas y calumniosas diatribas contra la Jerarquía y para sembrar mayores odios en el pueblo contra la Iglesia». También veía claro que la guerra era una «cruzada religiosa y patriótica» para salvar «del marxismo y de los sin Dios» a España ${ }^{21}$.

Quizás esta concentración simplificadora de lo que era una guerra civil se explique por la necesidad de cohesionar el bando nacional, $;$ en ese momento fracturado incluso entre los monárquicos y hasta entre los carlistas. El cardenal Segura, cuando recibió al heredero de Alfonso XIII se limitó a prometer obrar en conciencia en esta «importantísima, pero difícil» cuestión dinástica. Fal Conde dijo al cardenal que Pretendiente carlista se ilusionaba con «esperanzas vanas en hombres y en tácticas de posibilismo» ${ }^{22}$.

El 7 de febrero Pío XI sugirió la idea de un documento episcopal, pues eso le permitiría intervenir usando como recurso su aprobación. No lo aceptó el cardenal Gomá, porque creía que era una opción equidistante y pensaba que era necesario que los obispos se pronunciaran a favor de los nacionales. El asunto quedó parado.

No esperó el Papa. Por medio de Mussolini, pidió a Franco que concediera a los vascos un parlamento. Había precedentes. Citaba Estados Unidos, Canadá y Suiza.

Con su falta de finura, Magaz reprochó a la Santa Sede que no simpatizara con la causa de Franco. No era verdad. Siendo mayores los abusos contra gente inocente en la zona republicana, Pío XI se pronunció contra ellos en su discurso de septiembre de 1936. ¿Cómo iba a callar ahora ante los que cometían los nacionales?

Vicente Cárcel Ortí lamenta que la cuestión vasca se resolviera con el fracaso de la mediación vaticana y con los bombardeos sobre poblaciones inermes. Cuando todo acabó, con la caída de Bilbao, la Santa Sede se interesó por la suerte de José Antonio Aguirre y de los niños vascos expatriados. Franco se libró de uno de los obstáculos en sus relaciones con el Vaticano. No quedaba más que conseguir unas condiciones para la rendición de Bilbao. Las transmitió Isidro Gomá al cardenal Pacelli el 7 de mayo, después de haber hablado con Franco y con Mola. Al menos se garantizaba la salida de los dirigentes nacionalistas, la libertad de milicianos y soldados, la vida y los bienes de los jefes militares, la

21 Isidro Gomá-Eustaquio Ilundain, Pamplona 26 diciembre 1936 y respuesta, Sevilla 4 enero 1937, $A G 1$ y $2,487-488$ y 64 .

22 Fal Conde-cardenal Segura, 25 febrero 1937, anotación del diario, 17 marzo 1937 Santiago MARTínez SÁncheZ, Lo papeles perdidos del cardenal Segura 1880-1957, Pamplona, EUNSA 2004, 410-411.

Hispania Sacra, LXI

124, julio-diciembre 2009, 691-753, ISSN: 0018-215-X 
promesa de una amplia descentralización, «análoga a las otras regiones que la disfrutan». Bilbao debía rendirse inmediatamente, antes de que las tropas de Franco ocuparan el «cinturón de hierro», últimas defensas de la ciudad ${ }^{23}$.

Asediada Bilbao y siendo eficaz el bloque marítimo, la ciudad tenía graves problemas de abastecimiento. Estaba todo listo para la batalla decisiva. Los nacionalistas estaban decididos a no rendirse. Se engañaban sobre sus posibilidades de resistir. Habían perdido hombres en la defensa de Asturias. El tiempo iba en contra de ellos. Las autoridades tenían cada vez más prejuicios, que dificultarán el arreglo de los problemas, cuando los nacionales controlaran la situación. Se complicaría la situación de los sacerdotes nacionalistas. Un anticipo era la conducta del Gobernador Civil de Guipúzcoa. Había una opinión que condenaba a los nacionalistas como traidores. Era previsible una reacción del pueblo contra la Iglesia al ver que sus curas lo habían engañado ${ }^{24}$.

\section{ALARMA INTERNACIONAL Y TOTALITARISMOS}

Pasados los primeros meses, había que echar cuentas. En el ministerio de Asuntos Exteriores francés se comentaba que la guerra en España entraba en una fase decisiva. Franco en poco tiempo podría vencer. Esa victoria militar dejaba intactos numerosos problemas. Para la Santa Sede podría ser una oportunidad «di far sentire al popolo spagnuolo e indirettamente al mondo intero, l'influenza del suo supremo magistrato di carità e di larga comprensione delle aspirazioni e dei bisogni delle varie classi sociali».

El nuncio Valerio Valeri sabía, de fuente segura, que Franco, en su momento, pedirá públicamente al Papa su mediación. Para el nuncio el porvenir de España pasaba por el triunfo de Franco sobre el anarquismo y el comunismo. La seguridad de que eso iba a suceder no la quebraba la derrota de los italianos en Guadalajara ${ }^{25}$.

\footnotetext{
${ }^{23}$ Vicente CÁrCEl OrTí, Pío XI entre la República... 276-281. El fracaso de la carta de los obispos de Vitoria y Pamplona, escrita por el cardenal Gomá, pudo reforzar la posición de la Santa Sede sobre la condena de la colaboración de los católicos con los comunistas. Vid. María Luisa RodRíGUEZ AisA, El cardenal Gomá y la guerra de España. Aspectos de la gestión pública del Primado 1936-1939, Madrid 1981, CSIC, 447-448 y 344. Vid. Fernando de MeER, «Mediación del Vaticano para la rendición de Bilbao: nueva versión de las peripecias de un telegrama enviado por monseñor Pacelli al presidente José Aguirre en mayo de 1937», Historia 16, 174 (1990 12-21. Los aspectos generales, Manuel GoNZÁlez Portilla, y José María GaRmendia, La guerra civil en el Pais Vasco:política y economía, Bilbao, Servicio Editorial, Universidad del País Vasco, 1988. La guerra civil en el País Vasco 50 años después. Ponencias y Comunicaciones Presentadas a las Jornadas Celebradas en Bilbao en Febrero de 1987, Carmelo Garitaonandia y José Luis de L Granja (eds.) Bilbao, Universidad del País Vasco, 1987.

${ }^{24}$ Gomá-Pacelli, Toledo 28 marzo 1937, AG 4, 311-312.

251474 y 1523 Valerio Valeri-Pacelli, 15 y 22 marzo 1937, ASV Affari.Eclesiastici Spagna IV 889, 266, 21-25.
} 
Como apunte para una sesión de la Congregación para los Asuntos Eclesiásticos Extraordinarios, se presentó en marzo a los cardenales un informe sobre la tensión entre Alemania y la URSS ${ }^{26}$. Unos meses antes Polonia parecía vincularse a Francia. Ahora parecía haber pactado con Alemania un ataque en Ucrania. Eso suponía que el litigio sobre Dantzig estaba resuelto ${ }^{27}$. En ese avance, Checoslovaquia cedería a Alemania territorio en la parte de su frontera con Ucrania. El norte sería para Polonia. El plan estaba listo. En él estaría quizás Austria.

Alemania está pidiendo ahora colonias en África. Reclamaba las que tuvo que entregar tras su derrota. No era esa su verdadera demanda. Su ejército no estaba listo para intervenir allí. Se trataba de una maniobra para encubrir este ataque a Ucrania.

La URSS conocía los datos. Se explicaban así las frecuentes reuniones de los jefes de Estado Mayor esos días, en los que hubo movimientos de tropas soviéticas hacia Ucrania.

El nuncio en Francia juzgaba que las circunstancias habían empeorado por la guerra de España y la tensión entre el Reino Unido e Italia. La situación cada vez se parecía más a la Paz de Amiens ${ }^{28}$.

Italia pudiera engañarse confiando en el apoyo alemán frente a Inglaterra. Estaba reciente la conducta del gobierno de Roma en 1915, luchando al lado de los enemigos de Alemania y Austria, después de haber sido sus aliados muchos años ${ }^{29}$. Austria podría ser anexionado por Alemania aprovechando la situación.

El nuncio Valeri conversó con Frangulis, un diplomático griego jubilado, residente en París. Creía que la situación era muy peligrosa. La única salida era una apelación de la Santa Sede a los gobierno y a los pueblos para evitar la guerra. La apoyaría Roosevelt, porque no se creía con autoridad ante los Estados totalitarios.

Edouard Herriot, presidente de la Cámara de Diputados desde 1936, coincidía con Frangulis. No excluyendo la posibilidad de que Roosevelt y la Santa Sede intervinieran, dijo al nuncio que prefería al Vaticano. La del presidente

\footnotetext{
26 Texto mecanografiado, 15 marzo 1937, ASV Affari.Eclesiastici Stati Ecclesiastici IV 547, 571, 4

${ }^{27}$ Hitler dijo a Schulthess, un ex consejero federal, que la paz estaba asegurada. Le habló de que jamás habían sido tan amistosas las relaciones de Alemania con Polonia. Estaba dispuesto a un tratado de paz con Checoslovaquia, a pesar del trato injusto que recibían los alemanes residentes allí. Entrevista del nuncio en Suiza con Motta, presidente de la Confederación. 2037 Filippo Bernardini-cardenal Pacelli, 12 marzo 1937, ASV Affari.Eclesiastici Stati Ecclesiastici IV 547, 571, 5-6.

${ }^{28}$ Fue un tratado de paz de Gran Bretaña con Francia, España y la República Bátava (Países Bajos), el 27 de marzo de 1802. Puso fin a la guerra de la Segunda Coalición. Apenas duró un año.

${ }^{29}$ Este giro, dado por Antonio Salandra, que apeló al «sacro egoismo», Brunello VIGEZZI, Da Giolitti a Salandra, Firenze, Vallecchi 1969.L'Italia unita e le sfide della politica estera:dal Risorgimento alla repubblica, Milano, Unicopli 1998.
}

Hispania Sacra, LXI

124, julio-diciembre 2009, 691-753, ISSN: 0018-215-X 
norteamericano debería iniciarse pidiendo a los gobiernos una tregua aduanera, para cerrar la guerra económica. Eso tendría efectos positivos en la situación internacional. Herriot enseñó a Valerio Valeri una carta de Bonnet, embajador de Francia en Washington. Estados Unidos podría declararse neutral en caso de una guerra europea. Una vía de solución sería proponer y acordar un desarme gradual y simultáneo. Lo hizo ya Benedicto XV, pero no fue escuchado

Herriot reconocía que Francia había cometidos errores después de 1920. No debió creer en un desarme total y unilateral de Alemania. Acusaba a los políticos de ser mentirosos. Había en Francia una opinión favorable a la Santa Sede. Aunque nadie planteó el desarme, había que probarlo, decía Herriot, al menos, para tener la conciencia tranquila. Esta insistencia en el desarme era vital, porque Édouard Daladier, ministro de la Guerra, le comentó que las únicas industrias que trabajaban día y noche eran las militares ${ }^{30}$.

El cardenal Pacelli recibió también esos mismos días $r$ un informe impreso en el que Georg Lukács exponía sus ideas sobre un nuevo orden en Centroeuropa ${ }^{31}$.

En este cuadro, se produce la consulta del cardenal Gomá el 18 de marzo de 1937 a los Metropolitanos sobre el reconocimiento del Gobierno de Franco por la Santa Sede ${ }^{32}$. Isidro Gomá no conocía esta información y análisis sobre situación europea.

Estos movimientos y noticias coinciden con tres encíclicas de Pío XI. Ninguno va dirigido a España. De los tres pueden hacer una lectura hispana los amigos de Alemania, los que deseaban una revolución roja y los católicos que, en cada bando, legitimaron la guerra subordinando su conciencia creyente a otras fidelidades. La sangrienta persecución sufrida por la Iglesia en las semanas anteriores hizo que pasara desaperciba la llamada a las vías «cívicas» en la Firmissimam Constantiam». La claridad de la denuncia del nacional-socialismo silenció en la España nacional, consintiéndolo el cardenal Gomá, la Mit Brennender Sorge.

En el lado republicano pudieron entender en la Divini Redemptoris, pocas semanas antes de la dura represión de los vencidos en Barcelona, lo que significaba la denuncia del terror stalinista. La llamada a ir al pueblo, a conocer y compartir sus condiciones de vida, era un mensaje para aquella Iglesia que vivió a gusto con la monarquía, incluso durante la Dictadura de Primo de Rivera. Estaba más cerca del poder que de la Santa Sede, como puede verse esos años en los despachos de nuncio Tedeschini.

301539 Valeri-cardenal Pacelli, 24 marzo 1937, ASV Affari.Eclesiastici Stati Ecclesiastici IV 547, $571,10-13$.

${ }^{31}$ Ideen über die Grundlagen zur Neuordnung Mitteleuropeas. Denkschrift. Un ejemplar ibidem $15-18$ y $23-26$.

32 María Luisa RodríGuez AisA, El cardenal Gomá... 423-424. 
Con el texto oficial en alemán y sin más notas que las bíblicas ${ }^{33}$, Pío XI dirigió a los obispos alemanes una encíclica para hablar de la situación de la Iglesia en el Tercer Reich. La Mit Brennender Sorge, del 14 de marzo de 1937, apuesta por la verdad ${ }^{34}$. Desde ella, al dirigirse a los sacerdotes, diseña Pío XI una alternativa a la moral nazi ${ }^{35}$.

El Concordato del 20 de julio de 1933 se debió a una iniciativa del Gobierno alemán ${ }^{36}$. Buscaba «tutelar la libertad de la misión salvadora de la Iglesia en Alemania y asegurar la salvación de las almas a ella confiadas, y, al mismo tiempo, el sincero deseo de prestar un servicio capital al pacífico desenvolvimiento y al bienestar del pueblo alemán» (nn. 3-4). Esos días la Iglesia en Alemania vivía bajo una «persecución, insidiosa o manifiesta» ${ }^{37}$.

Los católicos tienen derecho a recibir una palabra de verdad y de ánimo (n. 8). Agradece el Papa a quienes han mirado de frente ese «provocador neopaganismo, apoyado, desgraciadamente con frecuencia, por personalidades influyentes». Da las gracias con «reconocida admiración para todos los que en el cumplimiento de este su deber se han hecho dignos de sufrir, por la causa de Dios, sacrificios y dolores» (nn. 17 y 46). «El que mora en los cielos se burla de ellos» (Sal 2,4), de todos los que se endiosan y se creen ajenos a la mirada de

${ }^{33}$ En la edición alemana iban a final. En la española, incluidas en el texto. http://www.vatican. va/holy_father/pius_xi/encyclicals/documents/hf_p-xi_enc_14031937_mit-brennender-sorge_ge.html

34 «...No hay para mi mayor alegría que oúr de mis hijos que andan en la verdad (3Jn 4). Pero la sinceridad que corresponde a la grave responsabilidad de nuestro ministerio apostólico y la decisión de presentar ante vosotros y ante todo el mundo cristiano la realidad en toda su crudeza, exigen también que añadamos: no tenemos preocupación mayor ni más cruel aflicción pastoral que cuando oímos: Muchos abandonan el camino de la verdad (cfr. 2Pe 2, 2). (nn. 2 y 7 ).

35 «Por lo demás, este amor inteligente y misericordioso para con los descarriados y para con los mismos que os ultrajan no significa, ni en manera alguna puede significar, renuncia a proclamar, a hacer valer y a defender con valentía la verdad, y a aplicarla a la realidad que os rodea. El primero y más obvio don amoroso del sacerdote al mundo es servirle la verdad, la verdad toda entera; desenmascarar y refutar el error, cualquiera que sea su forma o su disfraz. La renuncia a esto sería no solamente una traición a Dios y a vuestra santa vocación, sino un delito en lo tocante al verdadero bienestar de vuestro pueblo y de vuestra patria» (n. 44).

36 Sobre las conocidas posiciones de Konrad Repgen y su controversia con Klaus Scholder a finales de los setenta, hubo una jornada de discusión, resumida por el profesor Thomas Brechenmacher, de la Universidad de Postdam, «La fine del cattolicesimo politico in Germania nel 1933 e la Santa Sede. La legge sui pieni poteri, il Concordato con il Reich e lo scioglimento del Partito del Centro. Stato e prospettive della ricerca, e nuove fonti, a 25 anni dalla controversia tra Scholder e Repgen». Tuvo lugar el 17 de junio del 2004, tras la apertura parcial del ASV para este período. Hay numerosas noticias sobre este asunto buscando en Google «Die Katholiken und das Dritte Reich». Repgen sostuvo que los Concordatos los quiso Pío XI, tal como dice en su encíclica a los obispos alemanes, para tutelar la libertad de la Iglesia frente al totalitarismo.

${ }^{37}$ El Papa denuncia la propaganda del Estado totalitario Nacional-socialista: «La prensa y la radio os inundan a diario con producciones de contenido opuesto a la fe y a la Iglesia y, sin consideración y respeto alguno, atacan lo que para vosotros debe ser sagrado y santo» (n. 40).

Hispania Sacra, LXI

124, julio-diciembre 2009, 691-753, ISSN: 0018-215-X 
Dios, obran el mal, abusando del débil, y lo desprecian considerando que la compasión degrada al hombre (n. 20 y 43).

Se estaba presionando a los católicos, con promesas de ventajas sociales y económicas, para que abandonaran la Iglesia. Era una «violencia tan ilegal como inhumana». Eran tentados como lo fue Jesús. Su respuesta debía ser la misma $^{38}$. Nadie puede pensar que una apostasía pública es compatible con una fidelidad interior. La manifestación, más clara e insidiosa, de ella es la «imagen de una iglesia nacional alemana». Ante eso, quien, «ya desde el principio, opone su no vigilante e inconmovible, presta un servicio no solamente a la pureza de la fe, sino también a la salud y fuerza vital de su pueblo» (nn. 24 y 25).

«El creyente tiene un derecho inalienable a profesar su fe y a practicarla en la forma más conveniente a aquélla. Las leyes que suprimen o dificultan la profesión y la práctica de esta fe están en oposición con el derecho natural» (n. 36). El Concordato establecía que el Estado alemán se comprometía a respetarlo, pero no fue fiel a lo pactado (n. 41$)^{39}$.

«Hemos pesado cada palabra de esta encíclica en la balanza de la verdad y, al mismo tiempo, del amor. No queríamos, con un silencio inoportuno, ser culpables de no haber aclarado la situación, ni de haber endurecido con un rigor excesivo el corazón de aquellos que, estando confiados a nuestra responsabilidad pastoral, no nos son menos amados porque caminen ahora por las vías del error y porque se hayan alejado de la Iglesia». Esperaba aún la paz con el Estado alemán. Trabajaba por ella, pero si no era posible, confiados en el poder de Dios, «había que defender los derechos y la libertad de la Iglesia» (nn. 50 y 52).

El 24 de abril, el cardenal Gomá informaba a la Santa Sede que la prensa había silenciado la encíclica. Hubo una excepción. Fue criticada en una emisión de la Radio de Salamanca, que reprodujo El Adelanto. Se trataba de lo emitido por «El Noticiero Universal», en su emisión del las 21,30 del 23 de marzo. Era una descalificación en toda regla. El Vaticano buscaba hacer el juego a los enemigos del Reich, atacando «la patria de los católicos alemanes» ${ }^{40}$.

\footnotetext{
38 «Apártate de mí, Satanás, porque está escrito: al Señor tu Dios adorarás y a El sólo darás culto» (Mt 4,10; Lc 4,8).

39 «Sabemos que muchísimos de vosotros, por ser fieles a la fe y a la Iglesia y por pertenecer a asociaciones religiosas, tuteladas por el Concordato, habéis tenido y tenéis que soportar trances duros de desprecio, de sospechas, de vituperios, acusados de antipatriotismo, perjudicados en vuestra vida profesional y social. Y bien sabemos que se cuentan en vuestras filas muchos desconocidos soldados de Cristo que, con el corazón dolorido, pero con la frente erguida, sobrellevan su suerte y buscan alivio solamente en la consideración de que sufren afrentas por el nombre de Jesús (cfr. Act 5,41).

40 Texto de la emisión de «El Noticiero Universal», de las 21,30 horas del 23 marzo 1937, AG 4, 278-282. Vid. también María Luisa RodRíGUEZ, El cardenal Gomá... 447-448. Sobre esta censura ejercida por falangistas contra los obispos y quienes tenían otra idea de lo que debía ser el Estado con la victoria de los «nacionales», José ANDRÉS-GALLEGo, ¿Fascismo o Estado católico?: ideología, religión y censura en la España de Franco, 1937-1941, Madrid, Ediciones Encuentro, 1997.
} 
El cardenal envió una traducción de la encíclica a los obispos españoles ${ }^{41}$. Les aconsejó que no la difundieran. La unificación en el Partido Único, FET y de las JONS, era aún precaria. Falange Española era «de tendencia más o menos hitleriana». El bando nacional necesitaba reforzar su unidad interna. Era un momento de hegemonía alemana. A ella parecía deberse el decreto de unificación de las milicias de los partidos que apoyaban el Movimiento Nacional. Fue una decisión apresurada y bajo presión. Todos habían perdido, incluidas Renovación Española y la CEDA. Isidro Gomá esperaba que los tradicionalistas contrapesaran la hegemonía de la Falange ${ }^{42}$, una orgnización que no era cristiana. Sus ideas eran una síntesis de fuerza y de pragmatismo social y nacional. Muchos de sus principios y de su estilo podrían incluirse entre los condenados por la encíclica. En los 26 Puntos de la Falange hay «ausencia de valores espirituales ${ }^{43}$.

Se publica el 19 de marzo de 1937 la segunda encíclica Divini redemptoris, condena doctrinal del comunismo ${ }^{44}$. Entre la nostalgia del paraíso perdido y la seducción del mal, emerge la civilización cristiana. En 1937 la larga historia de las perturbaciones sociales se encarna en la revolución. Como realidad o amenaza, el comunismo bolchevique «supera en amplitud y violencia a todas las persecuciones que anteriormente ha padecido la Iglesia. Pueblos enteros están en peligro de caer de nuevo en una barbarie peor que aquella en que yacía la mayor parte del mundo al aparecer el Redentor» (nn. 2-3). Incluso los éxitos quedan oscurecidos, porque el terror ha sustituido a la conciencia moral, como ha sucedido en la URSS bajo la dirección de Stalin ${ }^{45}$.

Entre los antecedentes de la clara posición de la Iglesia ante esa amenaza, «solemne protesta contra las persecuciones desencadenadas en Rusia, México y

${ }^{41}$ Al ver que no existía noticia alguna sobre la encíclica, pidió un ejemplar. «Por el sesgo que van tomando las cosas acá... no sería de más que se empezaran a tomar posiciones ante posibles actitudes de las autoridades, teniendo especialmente en cuenta que puede haber algunos elementos extranjeros que puedan pesar en el ánimo de los dirigentes de las cosas de España en un sentido poco acomodado a la trayectoria de su tradición, tan profundamente respetuosa con las cosas de la Iglesia». Gomá-Pacelli, Pamplona 4 abril 1937, $A G$ 5, 33-34.

42 «Nos afanaremos en triunfar en la lucha con solo las fuerzas sujetas a nuestra disciplina. Pactaremos muy poco. Solo en el empuje final por la conquista del Estado, gestionará el mando las colaboraciones necesarias, siempre que esté asegurado nuestro predominio». Punto 27, suprimido por Franco. Isidro Gomá cree que, con esa decisión, trataba de evitar la pretensión falangista de hegemonizar el futuro, eliminando a los otros competidores políticos.

43 Gomá-Pacelli, Pamplona 24 y 30 abril 1937, ibidem 5 abril-mayo 1937, 2003, 233-238 y 308315. El informe del 24 de abril, María Luisa RoDríGUEZ AisA, El cardenal Gomá... 432-435.

44 http://www.vatican.va/holy_father/pius_xi/encyclicals/documents/hf_p-xi_enc_19370319_divini-redemptoris_sp.html.

45 «Para sustituir este sentimiento moral no queda otro sustitutivo que el terrorismo que presenciamos en Rusia, donde los antiguos camaradas de conjuración y de lucha se eliminan mutuamente; terrorismo que, por otra parte, no consigue contener, no ya la corrupción de la moral, pero ni siquiera la disolución del organismo social» (n. 23).

Hispania Sacra, LXI

124, julio-diciembre 2009, 691-753, ISSN: 0018-215-X 
España» ${ }^{46}$, están la Dilectissima Nobis, dirigida a los católicos españoles el 3 de junio de $1933^{47}$ y el discurso a los prófugos españoles ${ }^{48}$.

El 24 de febrero de 1937 el P. Wlodomiro Ledokowski envió el borrador al $\mathrm{Papa}^{49}$. Justifica el haber tratado el materialismo dialéctico para ¡demostrar que se conocía bien el sistema marxista ${ }^{50}$. Tuvo interés en señalar las condenas de los Papas anteriores. La Santa Sede no actuaba movida solo por razones políticas. Creían los redactores del texto conveniente aludir a la influencia de los judíos en el comunismo. Menciona P. Ledokowski a Marx y a Ferdinand Lassalle. Había una notoria presencia de judíos en el comunismo soviético. En todas partes los principales propagandistas del comunismo eran los judíos.

Las citas del evangelio de Mateo y de la carta de Santiago ${ }^{51}$, desconocidas para muchos no cristianos, pueden hacer mucho bien. Se sitúan inmediatamente después de la mención a la obra benéfica de la Iglesia a favor de los obreros.

En el texto, sin que aparezca su nombre, se reproduce el discurso del primer ministro belga, Van Zeeland, en el Congreso Católico de Malinas, 10-14 septiembre 1936, y las palabras del primer ministro de Japón, en la recepción ofre-

${ }^{46}$ Los describe el Papa en la encíclica (nn.19-20).

47 «Discurso a los españoles prófugos con motivo de la guerra civil, 14 de septiembre de 1936, sobre las lecciones de la guerra española», Acta Apostolicae Sedis 28 (1936) 374-381.

$48 \mathrm{http}: / /$ www.vatican.va/holy_father/pius_xi/encyclicals/documents/hf_p-xi_enc_19330603_dilectissima-nobis_sp.html

${ }^{49}$ En el día de Pascua, tras la misa solemne, el P Wlodomiro Ledokowski recordó las palabras del Papa en la última audiencia en que lo recibió sobre el peligro del comunismo, que estaba penetrando en lo seminarios. Pensó si el Papa quería llamar la atención del mundo sobre este peligro que lo amenaza. ASV Affari Eclesiastici Stati Ecclesiastici IV 577, 548, 9. Texto mecanografiado»Appunto per la Segretaria di Stato», ibidem 573, 548,3-8. La primeras propuestas del texto, ibidem 12-78.

${ }^{50}$ El Papa aceptó esa indicación. «Queremos, por tanto, exponer de nuevo en breve síntesis los principios y los métodos de acción del comunismo ateo tal como aparecen principalmente en el bolchevismo, contraponiendo a estos falaces principios y métodos la luminosa doctrina de la Iglesia y exhortando de nuevo a todos al uso de los medios con los que la civilización cristiana, única civitas verdaderamente humana, puede librarse de este satánico azote y desarrollarse mejor para el verdadero bienestar de la sociedad humana» (nn. 7-14). En estos números resume «el pretendido evangelio nuevo que el comunismo bolchevique y ateo anuncia a la humanidad como mensaje de salud y redención». La contra-réplica doctrinal (nn. 26-34).

${ }^{51}$ El Papa, pidiendo una renovación espiritual de los católicos, además de los textos de (St 1,17 y 1, 22), citados en nn 42 y 39, incluyó, en los nn. 44-49, el alegato de la carta contra los ricos «Vosotros, ricos, llorad a gritos sobre las miserias que os amenazan. Vuestra riqueza está podrida; vuestros vestidos, consumidos por la polilla; vuestro oro y vuestra plata, comidos del orín, y el orín será testigo contra vosotros y roerá vuestras carnes como fuego. Habéis atesorado [ira] para los últimos días», que el autor sitúa en la perspectiva de la próxima llegada del Señor y su justicia (St 5, 1-8) y las citas del evangelio sobre la bienaventuranza anunciada por Jesús a los pobres (Mt 5,3 y Lc 6 20) y el texto del evangelio de San Mateo en el día de la venida de Jesús (Mt 25 34-45). 
cida al cardenal Dennis Dougherty, arzobispo de Filadelfia, publicadas en L'Osservatore Romano 19 febrero 193752.

El P. Ledokowski escribió de nuevo al Papa para que se publicara también como texto oficial la versión italiana y, como anexo, el discurso del Papa con motivo del Congreso Internacional de la Prensa Católica ${ }^{53}$. El Papa no aceptó la propuesta $^{54}$.

Se insta a que se convenza a seminaristas de la necesidad de que los sacerdotes vayan a las clases pobres, al pueblo, poniendo, si es preciso, aparte otras obras de su ministerio menos urgentes.

Pío XI, en la V parte de la Divini Redemptoris (nn. 63-85), recuerda la exhortación de León XIII, «que Nos hacemos nuestras completándola: «id al obrero, especialmente al obrero pobre y, en general, id a los pobres» (n. 64). Esa fue la enseñanza de Jesús y de su Iglesia siempre. Los sacerdotes deben reservarse la mayor parte de su fuerza y de su actividad para volver a ganar a las masas trabajadoras a Cristo y a su Iglesia y para hacer penetrar el espíritu cristiano en los medios que le son más ajenos». El Papa recuerda lo hecho en Roma: se han abierto parroquias en la periferia de la ciudad. El sacerdote, en medio del pueblo, debe ser pobre, humilde, desinteresado. Si no lo es, estorba (n. 66) 55 .

El esquema previo insiste en las causas religiosas que pueden explicar el ateísmo comunista. Se denuncia la responsabilidad de los cristianos, pues aceptan las verdades de la fe, pero viven solo para este mundo. Los comunistas quieren construir en la tierra el paraíso, de modo que no haya que esperar otro. Los católicos viven una fe débil y debilitada. Había mucha ignorancia religiosa y una casi total ausencia de vida religiosa en los ambientes populares, obreros, donde la propaganda comunista es mayor.

En muchos sitios hay inercia en el clero y las tradiciones religiosas están vacías de espíritu. Estas pueden ser las razones de que, en los países de seculares tradiciones cristianas, la propaganda comunista haya sido más violenta: España, México, Rusia.

\footnotetext{
52 Tras la carta y las explicaciones del P. Wlodomiro Ledokowski, viene un texto, el esquema aprobado por el Papa y las observaciones generales a los varios textos redactados, ibidem 574 2-66. Resúmenes oficiales de la encíclica en varias lenguas, ibidem 575 2-30.

5312 de mayo de 1936, Acta Apostolicae Sedis 29 (1937) 130-144. Fue incluido en la encíclica (n. 5).

54 Wlodomiro Ledokowski-Pío XI, 29 marzo 1937, ibidem 575 33-34. 12 de mayo de 1936: ASV Segr.Stato 29 (1937) 130-144. Fue incluido en la encíclica (n. 5).

${ }^{55} \mathrm{La}$ referencia al deber de ir al pueblo, valoración del esquema de la encíclica, sin fecha, citas de la encíclica (V nn. 61-63) Texto ASV Affari.Eclesiastici Stati Ecclesiastici IV 548574 64. La primeras propuestas del texto, ibidem 12-78.
}

Hispania Sacra, LXI

124, julio-diciembre 2009, 691-753, ISSN: 0018-215-X 
Urge separar del capitalismo explotador a la Iglesia e ir sinceramente al pueblo $^{56}$. No basta una buena doctrina social ni que el Papa hable con simpatía y amor a los humildes y a los oprimidos. Debe ponerse en obra valientemente su doctrina. El clero y la Acción Católica han de ser eco fiel de la palabra del Papa.

El clero tiene que vivir a la altura de su tiempo. Ha de formarse bien. Debe salir de una mediocridad que lo convierte en una casta, burguesa, de buena gente, sin relación con el pueblo, pues ni vive como los pobres ni conoce sus necesidades. Deben rejuvenecerse los seminarios: menos formalismo, mayor espontaneidad, sinceridad, formación espiritual. Ese mismo esfuerzo formativo debe hacerse con los laicos mediante la Acción Católica la instrucción religiosa catequística...

La distancia entre enseñanza y realizaciones, entre palabras y hechos, es dramática. Los católicos no siguen fielmente al Papa. Muchas reformas hay que hacer para adaptar la vida del clero, la estructura y extensión de las diócesis, el reparto de los bienes dentro de la Iglesia...

El mundo espera una renovación. O la hacen los cristianos o vendrá por una revolución. La Iglesia no debe temer los cambios, porque en ellos puede infundir el espíritu de Cristo mejor quizás que en la vieja y decadente sociedad actual ${ }^{57}$.

Ante el riesgo de que la encíclica se apague a los pocos días de su publicación y, en el contexto de una visión crítica de los estereotipos sobre la URSS ${ }^{58}$ y el comunismo, se reitera que «...tutti gli organismi dirigenti della Chiesa devono armonicamente collaborare a questa riconquista delle masse attraverso il sacerdote ${ }^{59}$.

Al mismo tiempo que pedía el texto y las instrucciones de la Santa Sede sobre la Mit Brennener Sorge, solicitaba el cardenal Gomá el de la Divini Redemptoris ${ }^{60}$.

\footnotetext{
56 «Para explicar mejor cómo el comunismo ha conseguido de las masas obreras la aceptación, sin examen, de sus errores, conviene recordar que estas masas obreras estaban ya preparadas para ello por el miserable abandono religioso y moral a que las había reducirlo en la teoría y en la práctica la economía liberal. Con los turnos de trabajo, incluso dominicales, no se dejaba tiempo al obrero para cumplir sus más elementales deberes religiosos en los días festivos; no se tuvo preocupación alguna para construir iglesias junto a las fábricas ni para facilitar la misión del sacerdote; todo lo contrario, se continuaba promoviendo positivamente el laicismo. Se recogen, por tanto, ahora los frutos amargos de errores denunciados tantas veces» (n 16).

57 Texto mecanografiado «Appunto per la Segretaria di Stato», ASV Affari. Eclesiastici Stati Ecclesiastici IV 548573 3-8. La primeras propuestas del texto, ibidem 12-78. El Papa reivindicó la obra de la Iglesia (nn. 36-38).

${ }^{58} \mathrm{La}$ documentación alerta sobre el riesgo de que los análisis mal hechos, las reflexiones poco equilibradas, como la de l'abbé Neveu, capellán de la iglesia de San Luis de los Franceses en Moscú, agravaran la situación de los sacerdotes y de los católicos en la URSS.

59 Texto mecanografiado sin firma ni fecha, ibidem 576 11. Otras sugerencias, texto manuscrito y mecanografiado, sin fecha ni autor, ibidem 13 y 17-21.

${ }^{60}$ Gomá-Pacelli, Pamplona 4 abril 1937, AG 5, 33-34. Se la envió Pizzardo el 7 de abril. Acusa recibo el cardenal, 16 abril, ibidem 70-71 y 160.
} 
A los pocos días, el 28 de marzo aparecía la Firmissimam Constantiam, dirigida al episcopado mexicano ${ }^{61}$. En su arranque, tres datos: la firmeza con que los católicos han resistido la persecución, el error de quienes, «ignorando la divina excelencia de la religión de Jesucristo y conociéndola sólo a través de las calumnias de sus enemigos, se engañan creyendo no poder hacer reformas favorables al pueblo si no es combatiendo la religión de la gran mayoría», y, finalmente, «muchos tibios o tímidos» cooperan en la descristianización de un pueblo que debe a la religión sus mayores glorias» (nn.1-2).

Los dos grandes remedios: la formación del clero y la Acción Católica (n. 4). La primera debe hacerse según el modelo trazado en la Ad catholici sacerdotii, del 20 de diciembre de $1935^{62}$. Es una tarea discreta y silenciosa, sin prisas y sin esperar resultados inmediatos ${ }^{63}$. Como Jesús, que se compadeció de la multitud (Mc 8, 2-3), los obispos deben cuidar que los sacerdotes y la Acción Católica trabajen para «resolver las graves cuestiones sociales que hoy perturban a vuestra patria, como por ejemplo, el problema agrario, la reducción de los latifundios, el mejoramiento de las condiciones de vida de los trabajadores y de sus familias».

Esta intervención les permitía ocuparse «con celo particular de la suerte de tantos pobres obreros, que tan fácilmente caen presa de la propaganda descristianizadora, engañados por el espejismo de las ventajas económicas que se les presentan ante los ojos, como precio de su apostasía de Dios y de la Santa Iglesia». Amar al obrero y a los campesinos, que son la mayoría de los mexicanos, «asemeja» más a Jesucristo (nn. 18-20).

Mencionó el Papa discretamente la reciente guerra cristera, aplicando los principios al caso mexicano: diferencias entre fines y medios. Estos han de ser siempre lícitos y no negar la misión pacificadora de los católicos y de la Iglesia. Su acción, «desarrollada con un espíritu noble y levantado, obtendrá resultados tanto más eficaces cuanto en mayor grado posean los católicos aquella visión sobrenatural de la vida, aquella educación religiosa y moral y aquel celo ardiente por la dilatación del reino de Nuestro Señor Jesucristo, que la Acción Católica se esfuerza en dar a sus miembros». Se crea así una «coalición de conciencias», que es invencible porque se asienta en la libertad y en la caridad de Cristo

${ }^{61}$ Texto latino, http://www.vatican.va/holy_father/pius_xi/encyclicals/documents/hf_p-xi_enc_ 19370328_firmissimam-constantiam_lt.html y traducción española http://ar.geocities.com/magisterio_iglesia/pio_11/firmissimam_constatiam01.html

62 http://www.vatican.va/holy_father/pius_xi/encyclicals/documents/hf_p-xi_enc_19351220_adcatholici-sacerdotii_sp.html

${ }^{63}$ «Este trabajo vuestro ha de ser sólido y profundo, ajeno a la notoriedad y al aparato, enemigo de métodos ruidosos; trabajo, que sepa desarrollar su actividad en silencio, aunque el fruto se haga esperar y no sea de mucho brillo, a manera de la semilla, que, soterrada, prepara con un aparente reposo la nueva planta vigorosa» (n. 13).

Hispania Sacra, LXI

124, julio-diciembre 2009, 691-753, ISSN: 0018-215-X 
(Gal 4, 31 y Rom 8 35) Desde estos fundamentos de su fe, cada uno sabrá cumplir sus deberes. «Conjuramos, por lo tanto, con toda Nuestra alma a los buenos católicos mejicanos a que tengan en grande estima y amen la obediencia y disciplina» (nn. 30-31 y 33).

\section{ENTRE EL HONOR DE DIOS Y DE LA RELIGIÓN Y LA PIEDAD Y LA JUSTICIA}

Cuando se publicaron estos documentos, ¿estaba la Santa Sede distanciándose de la España Nacional? Al menos se enrarecía «de una manera alarmante el amor y la adhesión tradicional» de los españoles al Papa. Cuando se daba por segura la victoria de Franco, había que pensar en qué condiciones podría negociarse con los ganadores. Nadie podría dudar del catolicismo de Franco. Los obstáculos vendrían por el trato de algunos católicos extranjeros a la España Nacional, es decir, a los españoles, que, según Pío XI, estaban defendiendo «el honor de Dios y de la Religión» ${ }^{64}$. La desconfianza era mutua. Unas declaraciones de Manuel Hedilla a Il Messagero preocuparon mucho a la Santa Sede. Temían en el Vaticano por el futuro de la Iglesia en España ${ }^{65}$. El suceso confirmaba una modificación en la actitud de algunos altos cargos dentro del Movimiento Nacional. La mayor seguridad era Franco. Ahora las circunstancias imponían la transigencia, pero se continuaba legislando a favor de la Iglesia. Franco desautorizó ante Gregorio Modrego, obispo auxiliar de Toledo, las palabras de Hedilla. Paso a paso se lograría la unidad, pero Franco estaba más cerca de los requetés que de los falangistas. Las relaciones con la Santa Sede serían reguladas por un Concordato.

La decisión de unificar las milicias y partidos y el discurso con que Franco presentó el decreto revelan su convicción de que la religión católica informará al nuevo Estado. Entiende el cardenal que el anuncio de un cambio de régimen supone una novedad, si bien nada se dice sobre sus rasgos ni sobre la restauración de la monarquía 66 .

La Santa Sede denunció la conducta del Gobernador Militar de Guipúzcoa con el clero de la provincia. Lo lamentó y pidió al cardenal Gomá que hiciera una gestión ante el Gobierno «Nazionale», para mejorar las penosas condicio-

\footnotetext{
${ }^{64}$ Nota anexa a la carta de Luis de Despujol a Carmelo Blay, 21 marzo1937, 4, 264. Agente de Preces en Roma, Carmelo Blay, operario diocesano, residente en el Colegio Español de Roma, fue confidente de la Secretaría de Estado desde los tiempos de Pío X. Siguió prestando sus servicios de la Santa Sede hasta el pontificado de Pío XII. Murió en Roma el 2 de marzo de 1941. Vicente CÁRCEL OrTí, Diccionario de Sacerdotes diocesanos españoles, Madrid, Biblioteca de Autores Cristianos, 2006, 233-234.

65 Pacelli-Gomá, Roma 5 de abril, $A G 5,45$.

66 Gomá-Pacelli, Pamplona 20 abril, ibidem 190-194.
} 
nes de los sacerdotes vascos represaliados. Quería Pío XI que el cardenal preguntara a Franco cómo podría facilitar la Santa Sede un acuerdo con los nacionalistas para un intercambio de rehenes ${ }^{67}$. Esta labor humanitaria era un deber ${ }^{68}$.

El cardenal Pacelli aceptó la información sobre las «vere carneficine, come facevano e fanno i rossi dove imperano», obra de los falangistas tras la toma de Málaga por los italianos.Se denunció que ni siquiera tuvieran en cuenta que muchos de los asesinados eran comunistas forzados por quienes mandaban en ellos. No respetaban la vida de los que se rindieron.

Aparte de ser moralmente condenable, esta conducta reforzaba la decisión de resistir. No cabía sino una guerra sin cuartel. Era, además un crimen, un error, porque daba argumentos a la propaganda contra la España Nacional en el extranjero. Por encargo del Papa, pedía el cardenal Pacelli a Isidro Gomá que se entrevistara con Franco para que para esos crímenes no se repitieran.

La respuesta del cardenal Gomá rectificaba las noticias que la Santa Sede daba por seguras. Todos los fusilados lo fueron tras ser condenados por un tribunal. Hasta el 23 de marzo lo habían sido $1038{ }^{69}$. Estos datos se los confirmó el P. Carmelo Ballester, paúl y visitador general de las Hijas de la Caridad en España. Se procedió «con toda justicia y equidad». Gomá aceptó esta información y fue más allá: para entender la represión había que ser testigo de los sucesos. El bando nacional respetaba las leyes de la guerra. Era excepcional que se violaran. «No creo que se dé en la historia, considerando el hecho en su magnitud y en sus formas repugnantes, tal cúmulo de afrentosa barbarie como se ha dado en el campo rojo estos meses» ${ }^{70}$.

El cardenal Gomá escribió unos días antes, impresionado por las noticias sobre las 113 parroquias de de la diócesis de Toledo en la provincia de Guadalajara. Habían sido asesinados casi todos los párrocos y sacerdotes. Algunos fueron

${ }^{67}$ Pacelli-Gomá, 20 marzo 1937, en María Luisa RodríGuez AisA, El cardenal Gomá... 419-420 y $A G$ 4, 261-262.

${ }^{68}$ En los días siguientes se intentó el canje de Buenaventura Pujol, rector del Pontificio Colegio Español en Roma, y de Manuel Irurita, obispo de Barcelona. Giuseppe Pizzardo-Gomá, 6 abril 1937 y Pacelli-Gomá, 7 abril, AG 5, 54 y 71. Informaciones sobre estos dos canjes, Gomá-Pacelli, 20 abril, ibidem 194-195. En una carta, recibida por las hermanas del obispo, residentes en Pamplona, se informaba que estaba «bien y en libertad», «en perfecta salud y en casa de unos amigos». Gomá-Pacelli, 22 noviembre, $A G 8,381$.

${ }^{69}$ No era exagerada esa cifra, teniendo en cuenta que durante el dominio rojo, fueron asesinadas en Málaga más diez mil personas honradas, sin otro delito que su posición social o sus ideas conservadoras y religiosas. «Los fusilamiento, recoge Gomá, fueron repercusión de la justicia contra la barbarie erigida en sistema».

70 Pacelli-Gomá, 5 marzo 1937 y respuesta 30 marzo, AG 4. 93-94 y 318-322. Documento original Gomá-Pacelli, 30 marzo 1930 ASV Affari.Ecclesiastici Spagna IV 889. 266. 12-14.

Hispania Sacra, LXI

124, julio-diciembre 2009, 691-753, ISSN: 0018-215-X 
mutilados. Sus hermanas, que les atendían, fueron atropelladas. Los mejores católicos también habían sido asesinados. Las iglesias, sacrílegamente profanadas y destruidas. «En toda esta catástrofe de la Iglesia... aparece el odio sistematizado, tenaz, satánico de verdad, con que el espíritu forastero del judaísmo y comunismo internacional, utilizando las masas de españoles engañados, ha ido a la destrucción de cuanto representaba la persona y las funciones de Cristo en nuestra sociedad $\gg 71$.

A mitad de abril l'abbé Lagarde, profesor el seminario de Metz, visitó Madrid habló con el P. Leocadio Lobo ${ }^{72}$. En Valencia estuvo con Manuel de Irujo y un sacerdote a quien nadie conocía como tal. Algunos sacerdotes, que salvaron la vida entrando en los sindicatos y en la policía. le informaron sobre los juicios a sacerdotes. Eran condenados a muerte por ser sacerdotes, por negarse a decir que dejaban de serlo. «Dans tout cela on ne voit pas trace d'une condamnation pour raison politique ou autre».

La Constitución seguía en vigor. En ella se reconocía la libertad religiosa. En Valencia habían sido asesinados más del 50\% del clero y el 30\% de los seminaristas, entonces en casa de sus familiares. En Madrid, 70\% del clero. En Barcelona el porcentaje era mayor y parece que habían sido asesinados casi todos los seminaristas.

Los ministros reconocían que no era posible ejercer la libertad religiosa. Manuel de Irujo condicionaba su restablecimiento al desarrollo de la guerra favorable a la República. Los nacionalistas tenían un argumento. Habían sido fusilados por Franco cuarenta curas vascos. Es un dato equivocado, como hemos dicho antes. Los más optimistas creían que podría abrirse a alguna iglesia, pero existía el riesgo de que los anarquistas no lo aceptaran ${ }^{73}$.

Desde diciembre de 1936 el cardenal Gomá era representante oficioso Santa Sede ante el Gobierno de Burgos ${ }^{74}$. Días antes, estando en Roma, el cardenal informó sobre la situación de España y la necesidad de reconocer a Franco ${ }^{75}$.

71 Gomá-Pacelli, Toledo 28 marzo 1937, AG 4, 309-310. La reacción del Papa ante este «cuadro tristísimo», Pacelli-Gomá, AG 5. 110. La situación en los pueblos de Toledo, José María Basés-Gomá, Molina de Aragón, 13 abril, ibidem 144-145.

72 Sobre la situación en Madrid y otros lugares, «Relation de la Supérieure des religieuses du Sacre Coeur de Jésus de Madrid, Leganitos 36», 20 abril 1937 texto mecanografiado ASV Affari.Ecclesiastici Spagna IV 889, 266, 39-86.

${ }^{73} \mathrm{El}$ informe, 8 páginas mecanografiadas, fue enviado por el nuncio en París, 1755 Valerio ValeriPacelli, 20 abril 1937, ASV Affari.Ecclesiastici Spagna IV 889, 266, 89-98.

74 Texto con el nombramiento, Pacelli-Gomá, 19 diciembre 1936, AG 1, 448-449,

75 Los documentos informando de la situación, el ambiente que encontró y su postura favorable, AG 1, 404-434. Sobre el viaje, Antonio MARQuina, La diplomacia vaticana y la España de Franco (1936-1945), Madrid, CSIC, 1983, 51-52. Sobre el nombramiento y las instrucciones dadas al cardenal Gomá el 19 de diciembre, María LuISA Rodríguez, El cardenal Gomá... 398-400. 
Corría prisa un reconocimiento pleno, pero el mismo Magaz sabía que Pío XI no estaba muy dispuesto ${ }^{76}$.

Valoró Isidro Gomá la situación el 8 de abril. Se formaría un Gobierno estable, en cuanto se conquistara Madrid. Entretanto, los ministros se mostraban favorables a los intereses de los católicos, especialmente en la enseñanza y en la formación religiosa de la juventud. Algunos problemas, como la ordenación del clero castrense, venían de la tradición regalista, tan fuerte en España: el Estado regulaba los asuntos que afectaban a la Iglesia, sin ponerse previamente de acuerdo con los obispos y con la Santa Sede ${ }^{77}$.

Franco había declarado, al inaugurar Radio Nacional en Salamanca: «haremos una España católica, con sus santos y sus mártires, con su caridad cristiana. Y con estos sentimientos, siguiendo nuestra trayectoria histórica, unificaremos todo aquello que pueda separarnos». Había crecido la asistencia del pueblo a las celebraciones religiosas.

El movimiento halló España dividida en dos campos. Si Franco alcanza la victoria, todos los partidos desaparecerán. Denuncia Gomá la infiltración de «elementos marxistas» en la Falange de Zaragoza. Era un mal presagio. Los genuinamente católicos, los requetés, carecían de experiencia política y les faltaban hombres preparados para gobernar. Renovación Española, una fuerza escasa en número, se aproximaba a los tradicionalistas, buscando la restauración de la monarquía. José María Gil Robles había disuelto Acción Popular. La medida estaba justificada.

La crítica de Isidro Gomá a la situación política recogía la tradición regeneracionista de los años anteriores. La República no fue una rectificación. En este ambiente destaca Franco, cuyas ideas sanas necesitan talento y fuerza para realizarlas en la vida nacional ${ }^{78}$. Quiso que en el Vaticano pudieran valorar en su

76 «... el nombramiento templa en gran medida la impaciencia que los católicos españoles debemos sentir por obtener de la Santa Sede un reconocimiento pleno y de derecho del Gobierno Nacional». Antonio Magaz-Isidro Gomá, Roma 8 febrero. Respuesta del cardenal, 3 abril, AG 3 y $5 \ldots 152$ y 31-32. La posición favorable de Isidro Gomá con el voto secreto de los Metropolitanos, 7 abril, María Luisa RodríGUEZ Aisa, El cardenal Gomá... 420-425. Carta de Magaz al sacerdote Ángel Barrio, 9 abril, $A G 5,104$.

${ }^{77}$ Isidro Gomá pensó elaborar un pequeño tratado de derecho público eclesiástico sobre la situación de los intereses católicos en España. La Santa Sede lo consideró una iniciativa conveniente frente a posibles y peligrosas desviaciones. Pacelli-Gomá, 24 y 26 abril 1937, AG 3 244-245 y 261. Alabando su contenido y su intención, censuró que se hubiera aprobado, sin contar con la Iglesia, el decreto de la Comisión de Cultura y Enseñanza, pidiendo una relación del ajuar litúrgico a todos los obispos con el fin de distribuirlo entre iglesias destruidas o dañadas, 28 de enero. Gomá-Pacelli, 30 abril, AG 5, 305-308.

78 «Largos años de política bastarda, distanciada del espíritu nacional, atenta, más que a las necesidades del país, al medro personal y de partido, han disociado las fuerzas sanas, que apenas sentían ya el estímulo de reacción ante los males de todo orden que aquejaban al pueblo español. El movimiento militar ha encontrado a España dividida en dos grandes campos: el dominado por la ideología marxista en

Hispania Sacra, LXI

124, julio-diciembre 2009, 691-753, ISSN: 0018-215-X 
justa medida la realidad de España, para que pudieran entender lo que significaba la influencia alemana ${ }^{79}$.

La guerra podría durar. En el bando republicano esperaban resistir hasta que se encadenase con un conflicto europeo. No era esa la posición de Azaña. A las potencias les correspondía limitarlo a España, y a los españoles, el deber de acabarlo. Cuando se marcharan los extranjeros, los españoles no querrán batirse y, si lo quieren, no podrán.

Azaña fue perspicaz para entender la política exterior. Si se hubiera confirmado la hipótesis de los que deseaban que la guerra en España continuase hasta que se desencadenara una en Europa, el papel de España hubiera sido muy secundario. Por lo demás,»la orientación que la España actual podría dar a su política exterior responde a móviles más duraderos y profundos que una momentánea coincidencia de intereses». El 17 de mayo formó Gobierno Juan Negrín. Era ministro de Hacienda en el de Largo Caballero. Asumió la cartera de Defensa Nacional el 5 de abril de 1938.

Los sucesos de mayo en Barcelona confirmaron la tesis de Azaña sobre la cuestión catalana y la fragilidad de las formas liberales. Estas no ponen fuera de la ley a los disidentes, por eso, entre los españoles, «han vivido siempre en peligro». Sin embargo, las soluciones de fuerza han demostrado que no venían a salvar un Estado en peligro», sino a confiscarlo en provecho de una facción de descontentos ${ }^{80}$.

El nuevo Gobierno se propuso también modificar la imagen exterior de la República. Manuel de Irujo fue ministro de Justicia desde el 17 de mayo hasta el 10 de diciembre de 1937. Volvió a ser ministro sin cartera hasta el 16 de agosto de 1938. De esos meses ha quedado un memorial al Consejo de Ministros. En él se denunciaba los excesos, ajenos a todo derecho, cometidos contra la Iglesia, sus objetos de culto, sus bienes y las personas ${ }^{81}$. Esa lista de abusos,

sus distintos grados, desde el socialismo al anarquismo, y el de ideas conservadoras, desde el tradicionalismo al republicanismo moderado y simpatizante con la situación creada en 1931. Los dos campos estaban formados por partido heterogéneos, con ventaja de mayor sentido de unión y de empuje mayor en las izquierdas». Gomá-Pacelli, Pamplona 8 abril 1937, $A G$ 5, 81-88, texto citado ibidem 86 y María Luisa RodRíguez AisA, El cardenal Gomá... 425-431, texto citado 429. Ese mismo día solicitó al cardenal Pacelli autorización para hacer una cuestación internacional a favor de las iglesias destruidas en España, $A G$ 5, 74-76. Gomá-Pacelli, Pamplona 26 abril, ibidem 429. Informe completo, ibidem 425-431.

${ }^{79} \mathrm{El} 30$ de abril, en un nuevo informe amplió las noticias sobre el protestantismo y el «hitlerismo», ibidem 308-315.

${ }^{80}$ Manuel AZAÑa, Causas de la guerra de España, Prólogo de Gabriel Jackson, Barcelona, Grupo Editorial Crítica 1986, 67-68 y 119-120. La insurrección de mayo, último episodio de esa trágica historia, dejó centenares de muertos, ibidem 125-126.

${ }^{81}$ El 1 de mayo el cardenal Gomá consultaba al cardenal Pacelli un formulario para que los obispos, a modo de anexo a sus «Relatio ad Limina», informaran a la Santa Sede de lo sucedido en su diócesis desde que estalló «la sangrienta revuelta». $A G 5,324-349$. Había que echar las cuentas para conocer las causas y medir sus consecuencias en la vida de la Iglesia. 
de contrafueros, parecía indicar que la religión era una cosa que no se restablecería en España, si la República ganaba la guerra. Existía «la prohibición absoluta de retención de imágenes y objetos de culto. La policía, que practica registros domiciliarios, buceando en el interior de las habitaciones de vida íntima, personal o familiar, destruye con escarnio y violencia imágenes, estampas, libros religiosos y cuanto con el culto se relaciona o lo recuerda» ${ }^{82}$.

Tras el bombardeo de Durango el 31 de marzo, un telegrama informa a la Santa Sede de los daños causados. El cardenal Gomá, su agente oficioso ante Franco, pide el 13 de abril noticias al vicario general de la diócesis de Vitoria, Antonio María Pérez Ormazábal ${ }^{83}$.

\section{AHORRAR SUFRIMIENTOS Y RECLAMAR LIBERTAD DE CONCIENCIA}

El Comité Français pour la Paix et la Liberté Religieuse en Espagne surgió a petición de los españoles residentes en Francia y como iniciativa de los católicos. Formaban parte de él Maritain, Mauriac, Gabriel Marcel, Mounier, Louis Le Fur, Daniel Halevy, Georges Duhamel. Acogía a todos los que respetaran la libertad de conciencia. Era independiente de los partidos y no tenía una posición política. Trataba de paliar los males de la guerra, favoreciendo o proponiendo iniciativas, y trabajando para atenuar las represalias.

Buscaba la paz no por la victoria de las armas, sino mediante una pacificación. En ella podrían colaborar los Estados, con su mediación. Sabían sus socios que estos organismos suscitaban recelo. Por eso el Comité realizaba discretamente su labor humanitaria,rectificando informaciones falsas, creando opinión y buscando que facilitara una mediación pacificadora. Finalmente quería que los parlamentos pidieran a los Gobiernos que actuaran a favor de la paz.

Una de sus tareas era atenuar el resentimiento, que una guerra civil desencadena y justifica las represalias. El Comité juzgaba su deber favorecer el respeto a la libertad de conciencia. Los miembros católicos querían testimoniar que el cristianismo trasciende el orden político y temporal. Hasta que no la haya en España «aucun effort pour assurer la paix européenne ne pourra être efficacement tenté» 84 .

Un telegrama enviado al cardenal Pacelli, calificaba los bombardeos sobre Durango y Gernika como «un riesgo» de exterminio del pueblo católico vasco. En el Vaticano acusaron recibo. Esperaban conocer los hechos. Recordaban que

82 A. de Lizarra (Andrés Irujo Ollo) Los vascos y la República española, Contribución a la historia de la guerra civil, Editorial Vasca Ekin, Buenos Aires 1944, 201 y ss. El autor es hermano del ministro.

83 Isidro Gomá-Pérez Ormazábal, Pamplona 9 abril, AG 5, 142-143

${ }^{84}$ Documento dactilografiado, sin fecha, copia en ASV Affari.Ecclesiastici Spagna IV 889, 267, 6-7.

Hispania Sacra, LXI

124, julio-diciembre 2009, 691-753, ISSN: 0018-215-X 
siempre habían condenado la acción contraria a la humanidad, a la caridad y a la justicia, «da qualsiasi parte che essa provenga» 85 .

El Gobierno vasco envió otro telegrama al cardenal Pacelli desmintiendo la versión de que fueron ellos los que destruyeron Gernika. Fueron los mercenarios al servicio de los fascistas españoles. Las naciones civilizadas deberían protesta por ese acto, por las muertes de personas indefensas y por el objetivo de acabar con lo que significaba la villa de Gernika. Deberían ayudar al Gobierno vasco para atender a los trescientos mil refugiados en Bilbao ${ }^{86}$.

Gustavo J. Franceschi, prelado doméstico del Papa, canónigo de la catedral de Buenos Aires y rector de la iglesia del Carmen, pasó por España y entregó a Isidro Gomá ayudas para la Iglesia ${ }^{87}$. Viajó luego a Roma. Había sido presentado a Pizzardo por el nuncio en Argentina.

En su informe destacó la superioridad económica y militar de Franco. Tenía dos tercios del territorio y más de la mitad de la población, 13 millones sobre 22 millones. Tenía puertos para aprovisionarse y estaba pagando con productos agrarios y con minerales las compras que hacía. Alemania e Italia habían modernizado, con su armamento, al ejército nacional, especialmente la aviación y la marina. Desde enero las tropas de Franco habían ido avanzando.

La unificación política y la insistencia patriótica en la unidad frente a las escisiones en la zona republicana, y de toda España frente a la tolerancia hacia el separatismo de catalanes y vascos... proporcionaban los nacionales una superioridad moral.

No dice Franceschi que la guerra sea una cruzada religiosa, pero afirma que estaba poniendo de manifiesto las hondas raíces católicas de la sociedad española. Para algunos combatir era defender la religión.

Un arreglo dejaría vivos los odios. Sería una tregua que abriría de nuevo el conflicto. En este terreno también los nacionales tenían superioridad: querían vencer y estaban convencidos de que vencerían.

La intervención extranjera era evidente. Había dos bloques. Alemania e Italia, a favor de Franco. Francia y Rusia, al lado de los republicanos. El Reino Unido era un caso aparte. Sus gobernantes eran reticentes con Francia. Se oponían al

85 1616/35 Pacelli-Valeri, 3 mayo 1937, ibidem 8. La respuesta del comité y la explicación de que se dirigieran directamente a la Santa Sede, por estar ausente el nuncio, Jacques Maritain-Pacelli, 8 y 9 de mayo, ibidem 10-11.

86 Telegrama recibido el 29 de abril, ibidem 25-26. Galbarriatu telegrafió, desde Bilbao, a Mateo Múgica, residente en el convento de los trinitarios en Roma. Le rogaba que interpusiera su influencia ante «los altos poderes» para impedir que continuaran esos procedimientos que confunden a ciudadanos pacíficos con beligerantes. El obispo lo envió al cardenal Pacelli el 29 de abril, ibidem 28

${ }^{87} \mathrm{El}$ cardenal Gomá informó al cardenal Eustaquio Ilundain sobre su encuentro con Franceschi, el 9 de mayo de 1937, $A G 5,338$. 
fascismo y tenían intereses en el Mediterráneo. Franco acababa de declarar que el Gobierno sería «español» y cumpliría sus compromisos con la Sociedad de Naciones. La prensa, bajo censura, había dejado de atacar a Inglaterra.

Había resentimiento contra los vascos, por ser separatistas. Creía Franceschi que Franco no se opondría a una amplia autonomía administrativa. Debería declararlo públicamente. La posición política del clero vasco, permitiendo que los católicos se alinearan con la izquierda, fue crucial para la supervivencia de la República y la prolongación de la guerra. La Santa Sede podría intervenir a favor de este clero, mediante una gestión amistosa ante Franco ${ }^{88}$.

Hay una penetración de la Action Française entre los católicos ${ }^{89}$. Estos no pueden aceptar los 26 puntos de la Falange, cuyas tendencias eran ajenas a la tradición española y carecían de arraigo. Eran imitaciones de lo foráneo. El Estado nuevo, en que pensaba Franco, según dijo a Franceschi, era un Estado no liberal, sino enraizado en el pensamiento político español.

El futuro de la Iglesia, dadas las pérdidas de clero a causa de la persecución, exigiría una redistribución de sus recursos humanos y económicos. Muchos templos habían sido destruidos.

«Prescindiendo de posibles errores pasados, es evidente que de hoy en adelante habrá de dejar en absoluto de lado lo político para lanzarse a un apostolado sin límites. Si la Acción Católica ha de ser el objeto primordial de sus cuidado, por otra, no habrá de mirar ya con desvío, cual sucedió quizás en tiempos pasado, los problemas de justicia social» ${ }^{90}$. Hay una identidad de ideas en este informe con las que el Papa acababa de proponer en la Firmissimam Constantiam y en la Divini Redemptoris: primar la formación del clero, su reforma, de modo que pueda acercarse al pueblo, y movilizar a los católicos mediante la Acción Católica.

\footnotetext{
${ }^{88}$ El predominio nacionalista en el clero no debe ocultar los hechos. De los más de 70 de sacerdotes y religiosos asesinados durante la guerra, 14 lo fueron por los nacionales. El resto durante el Gobierno de Aguirre y en la zona bajo su control. Aquellos fueron infamados, pues «no se hicieron por ellos los debidos funerales y en la mayor parte de los casos no se registró su muerte en el Boletín Oficial diocesano». Unos y otros se halla entre los centenares de personas «ejecutadas, víctimas de odios y venganzas». Mateo Múgica, el obispo, y muchos sacerdotes fueron represaliados por los vencedores. Documento de los obispos de las tres diócesis vascas, publicado el 30 de junio del 2009.

89 Sobre Action Française unas breves referencias. Charles MAURRAS, L'Action Française et le Vatican: les pièces d'un procès. Préface de Charles Maurras et de Léon Daudet. Paris. Flammarion 1927. Nicolas FonTaINe (Sed. de Luis Canet) Saint-Siège, «Action Française» et "Catholiques intégraux», Paris, Librairie Universitaire Gamber, 1928. E. WeBER, L'Action Française, Paris 1964, traducción del original inglés, Stanford 1962. L. Thomas, L'Action Française devant l'Église. De Pie X à Pie XII, Paris, Nouvelles Éditions Latines 1965. Cornelio FABRo, Charles Maurras et son Action Française, Paris, Perrin, 1966. Jacques PREVOTAT, Les catholiques et l'Action française. Histoire d'une condamnation 1899-1939, préface de René Rémond, Paris, Fayard, 2001.

${ }^{90}$ Gustavo J. FranCESCHI, «Memorándum sobre la situación de España en mayo de 1937», ASV Affari.Ecclesiastici Spagna IV 889, 268, 41-49.
}

Hispania Sacra, LXI

124, julio-diciembre 2009, 691-753, ISSN: 0018-215-X 
El 6 de mayo el cardenal Pacelli comunicó al cardenal Gomá el deseo de Pío XI de que se ahorrara sufrimientos a la población asediada en Bilbao. Emilio Mola, jefe de las fuerzas del Norte de España, recibió a Isidro Gomá. Le dijo que, mientras el Reino Unido pedia la evacuación de los niños, la Santa Sede la solicitaba para toda la población. Estas fueron las condiciones de Mola:

1. Mantener intacta la ciudad. Era una vindicación de la conducta del ejército nacional. Los rojos destruían las ciudades. Por eso era impensable que los nacionales hubieran ordenado la destrucción de Gernika.

2. Se daría facilidades a los dirigentes para que abandonaran la ciudad y España. Isidro Gomá aclara: el gobierno nacional no tiene interés en fusilar a los inductores políticos de la guerra.

3. Las tropas no cometerán excesos. De ese modo el ejército entraría sin lucha en la ciudad y se evitarán atropellos por parte del otro ejército y de las milicias.

4. Salvo los desertores, todos los demás soldados quedarán en libertad al entregar sus armas, si no son culpables de algún delito.

5. Serán juzgado los culpables de delitos contra el derecho de gentes, hayan cometido destrucciones y saqueos.

6. Se respetará la vida y los bienes de quienes se entreguen, incluidos los jefes militares.

Quiso Franco que se añadiera estas dos condiciones:

7. «Se concederá a Vizcaya la descentralización administrativa, en forma análoga a otras regiones favorecidas». Se estaba pensando en la situación de Navarra.

8. «En orden social se ofrece una justicia progresiva dentro de las posibilidades de la economía nacional, según el espíritu de la Rerum Novarum».

Juzgó Isidro Gomá generosas estas condiciones. Las operaciones contra Bilbao iban rápidas. Entre los defensores, según Mola, hay una proporción de 9/6 a favor de los nacionalistas. Si Aguirre no se rinde la situación puede cambiar a favor de los rojos y anarquistas. Daba por supuesto que Aguirre no se rendiría, pues cree que su resistencia le dará la victoria y confía en la ayuda inglesa. Lo sostiene Alberto Onaindía. Estaba, en cambio, a favor de la rendición Jaúregui ${ }^{91}$.

${ }^{91}$ El cardenal Gomá completa esta información con otros datos sobre Alberto Onaindía y la situación en Vizcaya. Informa de los asesinatos del párroco de Mugica y de un coadjutor de Rigoitia, dos pueblos cercanos a Gernika, y de la destrucción de la parroquia de Lumo, $A G 5,438-441$. Onaindía fue censurado por el cabildo de Valladolid, al que pertenecía. Isidro Gomá vincula el agravamiento del arzobispo, Remigio Gandásegui como consecuencia del disgusto que le provocó ese acto. Documentos sobre Onaindía y su posición política, ibidem 378-380 y Gomá-Pacelli, 17 mayo 1937, ibidem 434435. Sobre la expatriación de Aguirre, María Luisa Rodríguez AisA, El cardenal Gomá... 453. Sobre la caída de Bilbao, cardenal Gomá-cardenal Pacelli, 1 junio 1937, AG 6, 102 y documentos anexos. 
No la hubo. No quedaba más salida que una gestión humanitaria ${ }^{92}$. Pío XI apeló a Franco como católico. Debía evitarse a los nacionalistas vascos un inútil derramamiento de sangre y una humillación vergonzosa. Aunque de forma confusa, el telegrama distingue entre las autoridades y los vascos, que son un pueblo cristiano. El Papa pedía a Franco que no se les impusiera condiciones y condenas inaceptables. Franco aceptó «puramente e semplicemente proposizioni presentante» ${ }^{93}$.

\section{«SAUVER LA REPUBLIQUE, AU DESSUS DES EXTREMISTES»}

El 9 de mayo comentaba Isidro Gomá al Cardenal Eustaquio Ilundain que «la otra parte» trabajaba insidiosamente en el Vaticano. Para contrarrestar eso, informaba a la Santa Sede y aportaba documentos. Algunos atribuyen un gran ascendiente a la Iglesia sobre el régimen y le imputan sus errores. Esta tendencia se había reforzado ante el próximo reconocimiento de la Santa Sede. Veía con pesimismo una solución negociada con los vascos. Estaba citado con Franco el 10 de mayo en Burgos.

Punto central de lo tratado en la audiencia fue la «actitud adversa de gran parte de la prensa católica del mundo con España». Lo era especialmente la de Francia, Inglaterra y Bélgica. Secundaba la labor de algunos sacerdotes nacionalistas vascos y del canónigo José Gallegos Rocafull94. El Cardenal Gomá hizo una larga lista de hechos y de diarios, incluido L'Osservatore Romano. Eso producía malestar.

A Franco le parecía llegada la hora de que «autorizadamente se ponga la verdad en su sitio y no se consienta que España sea víctima de la calumnia y del soborno, para el que se utilizan las riquezas robadas por el Frente Popular a la

\footnotetext{
Onaindía prosiguió su labor en el exilio. El 9 de diciembre envió al cardenal Gomá un informe sobre sus actividades, El cardenal lo remitió a Antoniutti el 12 de diciembre, $A G$ 8, 503-504 y 511.

92 Telegramas con la petición de Pío XI a favor de los nacionalistas vascos tras la rendición de Bilbao y la noticia de la gestión hecha por el cardenal Gomá, 18 y 22 junio y 8 y 11 de julio. María Luisa RodrígueZ Aisa, El cardenal Gomá... 447-448 y 454 463. Sobre la rendición de Bilbao y la relación entre el problema de los vascos y la carta Colectiva, esos días de mayo, ibidem 438-445 El informe del cardenal Gomá al cardenal Pacelli, 18 junio 1937, ibidem Vid. Gonzalo Redondo, Historia de la Iglesia en España (1931-1939) tomo II, Madrid, Rialp, 1993, 264-290. Sobre el PNV y la guerra civil, Fernando de Meer, El Partido Nacionalista Vasco ante la guerra de España (1936-1937), Pamplona, EUNSA, 1992.

93 Telegramas 15 y 19 Pacelli-Gomá y respuesta, 8 y 11 julio 1937, $A G$ 6, 77 y 409.

${ }^{94}$ El canónigo se defendió de las acusaciones del cardenal Gomá contra él, en una carta dando cuenta de su conducta. Salió de España. Primero estuvo en Bélgica. Desde el 14 de noviembre vivía en París, «y no he tenido absolutamente ninguna actuación política» desde esa fecha. Gallegos Rocafullcardenal Gomá, París 14 septiembre, $A G$ 7, 432-435.
}

Hispania Sacra, LXI

124, julio-diciembre 2009, 691-753, ISSN: 0018-215-X 
misma España, en la forma de depredaciones inauditas, por la cuantía y por la manera de realizarlas».

No dudada de que la Santa Sede tenía buena información sobre los vascos. Condenó claramente su cooperación con los comunistas. Había gente que trabajaba «sin interrupción» en el Vaticano a favor de los separatistas vascos. Propone que, sin previo acuerdo y paulatinamente, los obispos viajen a Roma y expongan a Pío XI lo que pasa en España.

Isidro Gomá hizo una insinuación sobre la actividad del cardenal Vidal i Barraquer. Trataba de neutralizar eso Isidro Gomá, apostando por Franco, persona de sanos principios católicos, de vida cristiana, «hombre de talento, justo, de autoridad suave y fuerte... a quien juzgo capaz y con ansia viva de hacer una España digna de sus glorias antiguas» ${ }^{95}$.

Isidro Gomá aceptará la versión de que Gernika ha sido destruida por los rojos. Comunistas y separatistas vascos incendiaron Eibar. El 25 de abril comenzaron a arder las iglesias en Bilbao. Podría la ciudad seguir la misma suerte que otras villas vascas ${ }^{96}$.

Por encargo de su Gobierno, el ministro de Portugal ante la Santa Sede entregó el 13 de mayo una pro-memoria con los datos que juzgan en Lisboa necesarios que sepa el cardenal Pacelli. Franco tiene superioridad militar sobre la República. Era evidente en la campaña en Vizcaya. Los republicanos no habían tenido iniciativa militar esos meses.

Internacionalmente, había que tener en cuenta la posición de Alemania e Italia. El Reino Unido no quería complicaciones en el Mediterráneo. Le interesaba que no creciera la influencia italiana, pero no le gustaba una victoria de los rojos en España. La mayoría de los franceses desean el triunfo de Franco, pero las esferas oficiales estaban ligadas al eje Valencia-Moscú. Preferían un arreglo que los librara de tener como vecino un país con desórdenes públicos. Les interesaba también que fuera así para asegurar la comunicación con sus posesiones en el Norte de África.

\footnotetext{
${ }^{95}$ Gomá-Eustaquio Ilundain, Pamplona 9 mayo 1937, AG 5, 388-389. Sobre la entrevista con Franco, cardenal Gomá-Cardenal Pacelli, Pamplona 12 mayo, ibidem 398-403. Sobre la caída de Bilbao, Isidro Gomá-Cardenal Pacelli, 26 junio 1937, ASV Affari.Ecclesiastici Spagna IV 891, 271,13-14 y $A G$ 6, 232.

${ }^{96}$ A través de Carmelo Blay, del Colegio Español en Roma, Isidro Gomá comunica: «Diga a todo el mudo que las villas quemadas lo han sido por los rojos de forma indubitable. He estado en aquel frente y he visto las pruebas. El sistema es correr cables embreados a lo largo de las casas de una calle y así ahorra entrar en todas: la mecha cuida de los demás. Es una infamia. Me temo sufra Bilbao la misma suerte». Tc 11 Gomá-Pacelli, 26 abril 1937 y texto mecanografiado 17 mayo 1937, ASV Affari.Eclesiastici Spagna IV 889, 267, 18 y 12. Fue la versión de Le Figaro. «Une enquête á Gernika des journalistes étrangers révèle que la ville n'a pas été bombardée. Les maisons avaient été arrosées d'essence et incendiées par les gouvernementaux», Le Figaro, Lundi 3 mai 1937.
} 
En la España nacional, aun con diferencias políticas, había orden. En la otra España, desorden económico y falta de autoridad. Los partidos luchaban entre ellos, como acaban de demostrar los sucesos de Barcelona ${ }^{97}$.

La situación apuntaba a que Franco saldría victorioso o, en el peor de los casos, no podría ser vencido. Una pacificación dejaría impunes los crímenes cometidos. Por eso no debería pensarse en ella hasta que se supiera que Franco no podría ganar. Mientras eso no suceda, la mediación es una táctica para salvar al frente popular. Portugal no la apoyaría.

Los católicos portugueses estaban del lado de su Gobierno. La Santa Sede no podía colocarse del lado de los comunistas, cuyas doctrinas acababa de condenar, pero «é claro nao se pensa que Santa Sé tome una posiçao clara a favor do nacionalismo católico». Las llamadas para humanizar el conflicto serían bien vistas, pero no la mediación, pues sería un acto político beneficioso para los comunistas ${ }^{98}$.

El 8 de abril, el embajador de Francia, Yvon Delbos, comunica al cardenal Pacelli que los dos bandos rechazan una intervención de la Santa Sede. El Gobierno francés la juzgaba prematura. Cuando creyera que era viable lo comunicaría. Podría trabajar con Francia y el Reino Unido para sondear las disposiciones de los dos bandos e intercambiar la información. Francia deseaba el final de la guerra civil. Aceptaría y apoyaría la intervención de un poder imparcial, en el caso de que tuviera posibilidades de éxito. Si no es así, se corre el riesgo de que se retrase el momento de la paz ${ }^{99}$.

El viaje del marqués de Magaz a Burgos podría tener relación con la propuesta de un armisticio. El representante de los nacionales en Roma iría a informar del ambiente en el Vaticano ${ }^{100}$.

La postura de la Santa Sede ante el movimiento revolucionario en España creaba equívocos. Había protestado por los excesos y las violaciones del derecho, pero no había entrado en el fondo político del conflicto. Quiso permanecer en una «imparcialidad cristiana», en la que estaba pesando la posición de los nacionalistas vascos.

Parece que Pizzardo habló en Londres, a donde fue con motivo de la coronación de Jorge VI, sobre un proyecto de armisticio, ya elaborado, y sobre la reti-

\footnotetext{
97 Una información de estos sucesos, Antonio Vilaplana-Pizzardo, Siena, 29 mayo 1936, ASV Affari Ecclesiastici Spagna IV 889, 267, 44-46

98 Documento mecanografiado, 13 mayo 1937, ibidem 32-36. este acto sólo tenía el valor de una información. Tc 43 Pietro Ciriaci-cardenal Pacelli, 16 mayo, ibidem 38.

99 Yvon Delbos-embajador de Francia ante la Santa Sede, 8 abril 1937, copia mecanografiada, ASV Affari.Ecclesiastici Spagna IV 889, 266, 35.

100 Sobre la posible mediación de la Santa Sede, Carmelo Blay-cardenal Gomá, Roma, 1 junio 1937, $A G 6,15$.
}

Hispania Sacra, LXI

124, julio-diciembre 2009, 691-753, ISSN: 0018-215-X 
rada de los voluntarios extranjeros, Todo quedaba en conjeturas. Era probable, pero no seguro ${ }^{101}$.

¿Qué vía seguir para llegar a un acuerdo en España que preserve la paz en Europa? Los ingleses creían que el Comité de Londres debería obtener una tregua que permitiera la salida de los voluntarios extranjeros

Lo propuso Anthony Eden. El primer punto, salvar las susceptibilidad de cada parte. No deberían creer que la mediación tenía fines ocultos y beneficiaba a la otra parte. El mejor apoyo era la voluntad de paz de un país cansado de la guerra. El primer paso, un acuerdo entre las cuatro potencias que estaban interviniendo y permitían así la prolongación de la guerra. Este acuerdo exige buena voluntad. Si falta, sólo quedaba insistir en que la guerra sólo servía para favorecer las miras de alguna potencia para controlar la política española. Así lo había dicho Eden en los Comunes.

El 22 de mayo de 1936 Giuseppe Pizzardo entregó en Lourdes a Isidro Gomá un documento. Partía de la susceptibilidad de cada uno de los dos bandos. «Une médiation étrangère dans la guerre civile espagnole est une affaire de psychologie». Cada uno buscaba hundir al otro y vencerlo. El mayor impulso hacia la paz era el cansancio de la población. El medio más eficaz para que esa fuerza a favor de la paz se manifestara en una eclosión de euforia, que la haga invencible, sería la acción unánime de las cuatro potencias que han dicho estar interesadas. Eso implicaba acabar con la intervención, «aussi malheureuse que passive, Dans leurs rivalités à elles, dont on profite pour souvenir la guerre».

¿Por qué no se llega a un acuerdo? ¿Es posible alcanzarlo? ¿Es sólo una cuestión de mala voluntad? Si es esto, nada puede hacerse, pero no debe consentirse que la guerra favorezca las miras de una potencia sobre la política interior de España, según declaró Anthony Eden en los Comunes.

Si se trata de buscar una fórmula de acuerdo, entonces hay que ponerse a la obra. La solución podría incluir estos puntos:

1. La no intervención reposa sobre la idea de restablecer la paz en España para poder preservarla en Europa. Las cuatro potencias, por este motivo, podría convenir revisar su acuerdo de no intervención si la continuidad de la guerra civil española demuestra que había sido ineficaz. Ese procedimiento, que pretende no herir la dignidad ni los sentimientos de los españoles, deja a las potencias la competencia indeclinable para verificar la eficacia de la no intervención.

2. El primer paso es preguntar a la Junta de Defensa si, en nombre de la paz y de la civilización europea, en cuya defensa dice estar luchando, estaría dis-

101 Madelaine R. ANGLES, «Le conflit Espagnol. Le Saint-Siège souhaite ardemment le rétablissement de la paix», Le Figaro, 26 mai 1937. Los documentos de estos contactos de Pizzardo con miembros del gobierno inglés, ASV Affari.Ecclesiastici Spagna IV 889, 266,102-108. 
puesta a una tregua o armisticio, que permitiera a las potencias del Comité de Londres estudiar, sobre el terreno, las posibilidades para que los españoles, libremente, aceptaran un arreglo pacífico. De ellas depende la permanencia o la revisión del acuerdo de no intervención.

3. Si Alemania e Italia lo quieren, la Junta de Defensa aceptará la propuesta. Si eso sucede, las potencias pueden dirigirse al Gobierno de la República. Recordando el compromiso en el Consejo de diciembre de la Sociedad de Naciones, se le podría pedir que se abstuviera de toda operación militar, ahora inútil, pues habrían cesado las hostilidades, y que permitiera a una delegación de las potencias ir a España durante esa tregua, para estudiar, con todas las garantías, las posibilidades de paz.

4. El documento califica de «extrêmement improbable» que la Junta Militar y el Gobierno puedan rechazar esta demanda y resistirse a la presión de la opinión española, pues serían acusados de querer la guerra.

5. Aceptadas las condiciones por el Gobierno de la República, la delegación, presidida por un neutral, se trasladaría a España, según lo aprobado por el Comité de Londres. Era el momento en que al prestigio de la delegación se sumara la fuerza de la opinión de los españoles por la paz, para procurar «sauver la République, au dessus des extrémistes (extrémismes) de (la) guerre civile».

6. Si esta iniciativa fracasa, las potencias quedaría libres de su compromiso y podrían buscar otras vías para restaurar la paz.

Antes de hacer pública esta gestión, podría haber una labor oficiosa, que facilitara su éxito.

El 25 de mayo respondió el cardenal Gomá. No temía que Franco, en el caso de que se convirtiera en dictador, ni por su temperamento ni por su formación religiosa, y sobre todo por sus actos y las medidas tomadas en favor de la Iglesia, gobernara como Hitler y Mussolini. Dio una señal Franco: hablando de los nombramientos episcopales, le dijo: «no quiero ser como los políticos del antiguo régimen monárquico que hacían obispos» 102 .

Si las cosas les eran favorables, pensaron los nacionales ¿para qué una mediación? Esos días, le dijo Rivas Cherif a Azaña: la guerra era una cuestión de ganar tiempo. No era el caso, replicó Azaña. Los facciosos aprovechaban el suyo y rectificaban sus errores. No tomarían Madrid «de frente y al asalto». No cometerían ese fallo, porque ya no necesitaban tomar la ciudad y se ahorraban

102 Junto a la comunicación que Mr Osborne envió a Pizzardo el 24 mayo 1937, hay un documento en francés, sin autor ni fecha. Los dos documentos, ASV Affari.Ecclesiastici Spagna IV 889, 268, 97101. Texto en francés, 22 mayo 1937. Respuesta del cardenal Gomá, Pamplona 25 de mayo, AG 5, 473475 y 496. Lo publicó María Luisa Rodríguez AisA, El cardenal Gomá... 447-452. Lo recoge Vicente Cárcel Ortí, Pío XI entre la República... 374-375. Acuse de recibo, Pizzardo-Gomá, 6 junio, AG 6, 65.

Hispania Sacra, LXI

124, julio-diciembre 2009, 691-753, ISSN: 0018-215-X 
bajas. Esta vez no se equivocó Azaña. En aquella conversación fijó el calendario de la derrota de la República ${ }^{103}$.

\section{LA CARTA COLECTIVA: ENTRE LA «IMPARCIALIDAD CRISTIANA»Y EL «PLEBISCITO ARMADO»}

Estaba pendiente el reconocimiento de Franco. ¿Tuvo miedo la Santa Sede a Inglaterra y lo retrasó? El 14 de junio de 1937 hubo una plenaria de la Sagrada Congregación de los Asuntos Eclesiásticos Extraordinarios. Había un informe de Pizzardo. Había estado en Londres, representando a la Santa Sede en la coronación de Jorge VI.

Algunos cardenales estaban a favor de mantener el statu quo para evitar represalias en la zona republicana. Otros creían que debía reconocerse a Franco a pesar de ellas. La posición del cardenal Raffaelo Angelo Rossi recoge todos los aspectos del problema. No debe cambiarse nada, pero se puede explicar a Franco la delicada situación de la Santa Sede. Deben seguir las relaciones tal como están, sin darles carácter oficial, como relaciones de facto, pero no de iure.

Fue el cardenal Francesco Marmaggi muy crítico con la idea de que la Santa Sede apareciera como beligerante. Para frenar el reconocimiento de Franco citó las «matanzas de Málaga». La Santa Sede debe estar siempre en condiciones de justificar su actuación y de trabajar en la pacificación. Para el cardenal Luigi Maglione, la Santa Sede no podía abrazar una causa, tan discutida aún en otras naciones.

Federico Tedeschini afirmó: todo lo que la Santa Sede podía hacer, todo lo que le había pedido Franco, estaba hecho ya: darle un concurso moral y espiritual. Salvo la conquista de Málaga, ninguna novedad en los frentes. La situación de la Santa Sede debe fijarse teniendo en cuenta que «nosotros no somos enemigos de los rojos. Nosotros buscamos principalmente a los enemigos». La Santa Sede podría mantener las relaciones con las dos partes. Debía evitar la sensación de que se deja presionar. No puede perder una posición que le permitirá jugar un gran papel en la pacificación.

La consulta de Isidro Gomá a los Metropolitanos, según Tedeschini, tiene trampa. Su resultado es cuestionable. Excluyó a Vidal i Barraquer, a quien se le

103 Ante el abandono de algunos y ante la sugerencia de una tercera España, siguió Azaña defendiendo la legitimidad de la República y de su Gobierno. No había excusa para equiparar a unos y otros, ni siquiera los desmanes del pueblo, de algunos insensatos y hasta quienes habían usurpado una autoridad «adventicia», podrían negar que la justicia estuviera «enteramente de nuestro lado». Cipriano de Rivas CHERIF, Retrato de un desconocido. Vida de Manuel Azaña (2), Barcelona, Grijalbo 1981, 370 y 382. El libro fue escrito entre 1941-1943, mientras el autor estaba en la cárcel. La primera edición en esta editorial es de 1979. 
ha dado «un bofetón indisimulable». La Santa Sede no se marcha, se deja expulsar. Tedeschini cree que debe esperarse a la toma de Madrid. De momento, la Divini Redemptoris, del 19 marzo 1937, dejaba clara la posición de la Iglesia en relación con el comunismo y con la persecución religiosa en España. Terminó el cardenal Tedeschini relatando los hechos y la conducta de la Santa Sede. Pizzardo aclaró en Francia, Inglaterra y Bélgica el carácter anti-religioso de la República y su persecución a los católicos ${ }^{104}$. La Santa Sede trabajaba para paliar las represalias sobre los prisioneros y frenar la infiltración nazi ${ }^{105}$.

Se acusaba a Pío XI de ser terco y estar entregado a Pizzardo, «también enemigo» de los nacionales. Había una lista de amenazas contra la Santa Sede y se afirmaba que la masonería estaba infiltrada en la Iglesia a través de la Acción Católica ${ }^{106}$.

La llamada «pastoral» de julio no fue una decisión beligerante. Pudo dar esa impresión el uso político de lo que en ella se dice. Puestas las cosas en sus fechas, hay antes una campaña, a raíz de la caída de Bilbao, Santander y Asturias. La represión, sobre todo la que afectó a los nacionalistas vascos, católicos, sirvió para denunciar que el bando de Franco no defendía a la Iglesia, ni la liberaba de la persecución sufrida en la zona que iba conquistando. No la hubo en el País Vasco gobernado por Aguirre. Sabemos, sin embargo, que los nacionalistas encarcelaron y bajo su Gobierno en Euzkadi fueron asesinados sacerdotes y otros católicos, como José María Urquijo, que les había abandonado en las elecciones de febrero ${ }^{107}$.

La entrada de Manuel de Irujo en el Gobierno de Madrid en septiembre de 1936, nada cambió. Continuó la persecución religiosa y la ausencia de libertad de culto. La propaganda de los nacionalistas vascos, empleando a la Iglesia para sus fines, originó primero la carta abierta de Gomá a Aguirre y, luego la «carta colectiva».

No se escribió antes, porque se quería apaciguar la persecución y porque Pío XI no quiso alinearse. No quería intervenir, sino mediar en solitario, por-

${ }^{104}$ Esos días primeros de junio los sacerdotes ocultos en Madrid enviaron a Giuseppe Pizzardo. Iba anexa una exposición al Papa. La carta se envió también al cardenal Gomá. Juan Ventosa, el 5 de junio, enviaba al cardenal Gomá La persecution religieuse en Espagne, Paris, Plon, 1937, con un poema-prólogo de Paul Claudel. AG 6, 52-59. Está editado parcialmente en Gonzalo Redondo, Historia de la Iglesia en España ... 280-282.

105 ASV Congregación para los Asuntos Eclesiásticos Extraordinarios, Rapporti delle sessioni 91, sessione 1372, sommario 43-66.

106 Informe con opiniones contrarias a la Santa Sede, $A G$ 6, 51-52. Sobre el distanciamiento de las autoridades nacionales, Gomá-Pacelli, 26 junio, $A G$ 6, 234-235.

107 José María de Urquijo e Ybarra. Opinión, religión y poder, Madrid, CSIC 1997, 657-677. Vid. la declaración de los obispos vascos citada en nota 88. El cardenal Gomá informó al cardenal Pacelli que se conocía el asesinato de 36 sacerdotes el 25 de junio, $A G 6$ 226-230. Al día siguiente le transmitió las noticias que el vicario general de Vitoria, Antonio María P. de Ormazábal le dio, tras visitar Bilbao, ibidem 232-233.

Hispania Sacra, LXI

124, julio-diciembre 2009, 691-753, ISSN: 0018-215-X 
que la Santa Sede carecía de intereses políticos y la situación internacional era esos meses muy tensa ${ }^{108}$. El presidente de la República Checa dijo al representante de la Santa Sede en Praga que deseaba comentar con él la situación ${ }^{109}$. El Rey Leopoldo de los Belgas escribió al primer ministro, van Zeeland el 21 de julio una carta llena de buenos deseos y de ilusiones. Abogaba por una «organización racional de la economía mundial», por una mística de la solidaridad humana. Creía segura la inclusión de Francia, Estados Unidos y el Reino Unido para establecer ese «orden mejor que reclama todo el mundo». El Rey era consciente de las dificultades de sus planes, pero estaba convencido de que podría intentarse. Occidente debía a Oriente un testimonio de que, por encima de las preocupaciones materiales, representaba una fuerza espiritual nacida de un verdadero sentimiento de fraternidad. Quiso que el Papa lo conociera ${ }^{110 .}$

La Carta Colectiva del 1 de julio de 1937, que tiene forma de circular, es la «culminación» de las manifestaciones de la jerarquía católica sobre la dimensión religiosa de la guerra. Su punto central es la condena de la cooperación de los católicos con los comunistas. No era una novedad. Según Gomá, reiterarla en este escrito era inútil. Creía preferible dirigirse a los católicos españoles.

El procedimiento debería ser consultar al episcopado, redactar un texto y someterlo a la aprobación de la Santa Sede. Sabemos que Pío XI quería un motivo para pronunciarse, pues estaba la Santa Sede obligada moralmente a trabajar por la paz en España. Su posición reservada era una condición para poder mediar. Había llegado el momento, pues estaba próxima la rendición de los nacionalistas vascos, cuya identificación como católicos se aceptaba. Dejó al cardenal Gomá la decisión sobre este asunto. El documento y la respuesta de los obispos del mundo ayudarían a ese objetivo ${ }^{111}$.

\footnotetext{
108 Notas diarias del cardenal Pacelli, 11 diciembre 1936, citadas por Vicente CÁRCEL, «La Chiesa tra le due Spagne», L'Osservatore Romano 1 aprile 2009, 5. Hay 26 fascícolos en dos bloques: 19301938 y 1933-1940. «Audienze S. Padre». ASV Affari Ecclesiastici Stati Ecclesiastici. Hay una nota en el índice: «Ediz. Riservata ASV». La actitud delicada de la Santa Sede y la posición exquisita para no herir a nadie quedan patentes en la razón por la que fueron recibidos los sacerdotes que entregaron una documentación sobre el problema religioso y humanitario en el País Vasco, Pacelli-Gomá, 10 junio 1937, $A G$ 6, 101-102. Hubo un desmentido del cabildo de Vitoria, que hizo suyo el cardenal Gomá y remitió al cardenal Pacelli, Pamplona 5 julio 1937. Ese mismo día respondió al cabildo, AG 6, 322 y 355. Comunicó este hecho a Juan Antonio Sangróniz, ibidem 356. Sobre el ambiente de rechazo a los sacerdotes nacionalistas, Gomá-Pacelli, Pamplona 13 y 16 julio, ibidem 425-427 y 454.

109 Acaba de reeditarse La guerra de las salamandras, del escritor checo KarelČapek, Barcelona, Gigamesh, 2009. Es una denuncia del ascenso del totalitarismo y de la falta de reacción de Europa. Se editó en 1936. La República Checa fue la única que se preparó ante la previsible invasión de Alemania, que sucedió en 1939.

110 Tc 19 Ritter-cardenal Pacelli, 2 julio 1937, ASV Affari.Eclesiastici Stati Ecclesiastici IV 571, 547,27 y $38-41$. Hay varias minutas de respuesta, porque no se quería criticar la poca consistencia de las ideas expuestas y su poco realismo, ibidem. 42-45.

111 Nota de la Secretaría de Estado al cardenal Gomá, 10 marzo 1937, AG 4, 166.
} 
El 10 de mayo Franco pidió al cardenal Gomá. Que rectificaran ana la versión de la guerra que estaba difundiendo el nacionalismo vasco. El cardenal Gomá se negó, dada la complejidad del asunto y la dificultad del momento. Lo hemos visto ya. Franco se quejó de la actitud de la opinión católica ${ }^{112}$. La novedad fue que el documento se dirigiera a los obispos de la Iglesia católica. Era lo que deseaba el Papa. El mismo medio, pero el fin de la Santa Sede no era el de Franco. Quiso este que el cardenal enviara una carta-consulta a los Metropolitanos, informando de lo hablado en ese encuentro ${ }^{113}$.

El 8 de junio había un esquema ${ }^{14}$. Tras recibir la respuesta de los obispos, Isidro Gomá se dispuso a redactar el texto, dando cuenta de las sugerencias recibidas $^{115}$. El documento apareció fechado el 1 de julioo ${ }^{116}$.

No debe olvidarse que se publica que preocupaba la creciente influencia nazi en el bando nacional a través de la Falange y la deriva política de las autoridades de Burgos, cada vez más agresivas hacia a Santa Sede.

El predominio nazi en las filas nacionales preocupó seriamente al Papa y al cardenal Pacelli. Condicionará toda la negociación con Franco ${ }^{117}$.

\section{LA MISIÓN CARITATIVA DE ANTONIUTTI EN EL NORTE}

La Santa Sede envió a España al hasta entonces Delegado Apostólico en Albania, Ildebrando Antoniutti118. Se le impidió el paso a en la frontera de Henda-

112 Puede verse, Genoveva García QueIPo DE Llano, Javier TuSEll GómEZ, «El catolicismo italiano y la guerra civil española», Boletín de la Real Academia de la Historia, 189/1 (1992), 43-88 y Javier Tusell Gómez y Genoveva García QueIPO DE LlAno, El catolicismo mundial y la guerra de España, Madrid, Biblioteca de Autores Cristianos, 1993.

113 Informe sobre la entrevista, Gomá-Pacelli, Pamplona 12 mayo 1937. La carta reservada del cardenal Gomá a los Metropolitanos, 15 mayo y el resultado de esta consulta, en el informe Gomá-Pacelli, Pamplona 25 junio y 5 julio 1937. El cardenal Gomá envió al cardenal Pacelli el 8 de junio las líneas generales del documento, María Luisa Rodríguez AisA, El cardenal Gomá... 346, 442-447, 461-462 y 453-454.

114 Cardenal Gomá-Cardenal Pacelli, 8 junio1937, AG 6, 81-82

115 Todos estaban a favor, salvo el cardenal Vidal i Barraquer, que «siguiendo su criterio apriorístico de que no conviene documento colectivo ninguno», le manifestó, antes de recibir el texto, que consideraba inoportuno el documento. Gomá-Pacelli, 25 junio y 5 julio, AG 6 213-214 y 323 . Vid. María Luisa RodríGUEZ, El cardenal Gomá... 461-463. Sobre la respuesta de los obispos, primero a la circular de 22 febrero en la que se les preguntaba sobre un documento colectivo y la respuesta al esquema, ibidem 329-330 y 324-328.

116 Se reproduce en $A G 6$ 331-350.

117 Este hecho quedó ya debidamente documentado por María Luisa Rodríguez Aisa y por Antonio Marquina. La documentación vaticana lo ha confirmado.

118 Iba destinado a Bilbao y tenía el encargo de estudiar con el cardenal Gomá, «in qual modo sia possibile procurare il titorno dei fanciulli baschi alle loro famiglie». Telegrama Pacelli-Gomá, 21 julio 1937, $A G$ 6, 529-530.

Hispania Sacra, LXI

124, julio-diciembre 2009, 691-753, ISSN: 0018-215-X 
ya, porque la Santa Sede mantenía relaciones con el Gobierno de Valencia. Le esperaba allí Luis de Despujol, secretario del cardenal Gomá. Llevaba un pasaporte extendido por la embajada de España en Roma. El jefe de la aduana dijo que pediría instrucciones. Todo quedó solucionado al día siguiente. Marchó a Pamplona y el 30 viajó a Salamanca.

El 31 de julio de 1937 Franco lo recibió en el palacio episcopal de Salamanca, su residencia. La audiencia la gestionó Isidro Gomá119. El delegado pontificio subrayó la presencia de signos religiosos en el edificio y que Franco estuviera en uniforme de campaña. La cruzada tenía un significado político, patriótico, que cada vez más fue integrando un horizonte religioso. Franco dijo a Antoniutti que el movimiento era t: una cruzada para revivir las antiguas gloriosas tradiciones católicas de los españoles. Le interesaba que fuera bien entendido en el exterior donde se desconocía la dimensión exacta de los sucesos de España antes de julio de 1936. Había que parar «la onda destructora roja». Con la paz se conocerá cuanto ha sido destruido en la zona controlada por los rojos.

El Papa sí había seguido de cerca y con interés los acontecimientos en España. Por eso, dijo Antoniutti «mi inviava appunto per occuparmi, a nome suo, del ritorno di tanti poveri bambini baschi che vivono all'estero, e per cooperare in altre iniziative caritatevoli in favore delle victime della guerra». Franco dio instrucciones a la Obra Nacional que atendía a los niños fuera de España para que colaborase con el delegado apostólico.

Una vez más aparece la interferencia del nacionalismo vasco y catalán. Franco comentó que algún obispo y muchos sacerdotes impedían sus proyectos para favorecer a la Iglesia, pues los militares estaban airados contra el clero nacionalista y exigían su castigo. Pedía moderación a las autoridades civiles y trataba de resolver este asunto contando con los obispos.

La reconstrucción económica y social se inspirará en las dos encíclicas: $R e$ rum Novarum y Quadragessimo Anno. Lamentó que el clero estuviera alejado del pueblo ${ }^{120}$. Debería acercarse a él y atender a la formación religiosa de la juventud $^{121}$. Ciertas teorías raciales no serán aceptadas en España. Cualquier apariencia en contra es solo una concesión provisional ${ }^{122}$.

De forma ambigua, la prensa bajo censura y oficiosa relacionó la «visita de Mgr. Antoniutti» con el reconocimiento del Gobierno de Franco, pero el dele-

119 Gomá-Pacelli, Toledo, 1 agosto 1937, $A G$ 7, 13-15.

120 «A guerra finita, bisogna che il clero sia l'animatore della vita del popolo. per attuare le giuste e sane riforme che ci proponíamos di fare. Bisgna che il clero spagnuolo dia al popolo una coscienza religiosa e sociale, e non soltando un culto liturgico esterno».

121 «A nessun altro dico questo... a guerra finita la gioventù sarà rinnovata e pacificata».

122 2/37 Ildebrando Antoniutti-Pacelli, Salamanca 1 agosto 1937, ASV Nunz.Madrid 968 528-529, editado en Vicente CÁRCEL ORTí, «La nunciatura de Madrid y la embajada de España...» 322-324. 
gado dijo venía en misión «di carità, come del resto ho avuto modo di dichiarare ripetutamente» ${ }^{123}$.

Fue acogido con desconfianza y sospecha. Las autoridades de Bilbao le habían recibido bien y le habían prometido cooperar. Los filo-nazi, como el jefe provincial de la Falange en Burgos, le dijeron que no era el mejor momento para su tarea. Los católicos estaban entusiasmados. La radio comenzó a subrayar con simpatía el gesto de Pío XI.

Tenía clara la situación. Se oponían a ella los nacionalistas vascos, incluidos los sacerdotes que salieron acompañando a los niños. Estos y los rojos hacían propaganda para impedir el retorno y, con ese fin, actuaban ante las autoridades de los países donde estaban refugiados. Habían falsificado los documentos de algunos, diciendo que eran hijos de personas que no eran sus padres.

Pensaba pedir la cooperación de los nuncios de las naciones donde había colonias de niños. Las autoridades de Burgos le pidieron que lo hiciera Era especialmente dramática y difícil la situación de los niños enviados a la URSS y a México ${ }^{124}$.

Con las primeras listas enviadas por medio de la Secretaría de Estado, había conectado con más de 500 familias. Había que superar los obstáculos puestos por los Gobiernos con representación en Valencia. Tenía una buena noticia. El de Londres deseaba que los niños instalados en Inglaterra regresaran a España. El de Francia exigía solicitudes legalizadas para cada caso. En Bélgica, los socialistas apoyaban al Comité Vasco, contrario al retorno de los niños. Los padres habían firmado una petición. Los localizó gracias a una proporcionada por la nunciatura en Bruselas ${ }^{125}$.

Sus informaciones le habían llevado a la conclusión de los niños salieron por motivos políticos, porque la ciudad no tenía víveres para poder alimentar a la población. Los niños estaban ilocalizables, porque a algunos padres no se les dijo donde iban y porque, cuando ellos mismos se dirigieron a las direcciones que les habían dado, nadie respondió. Muchos padres decían que habían sido engañados por la propaganda de los nacionalistas contra Franco. Normalizada la situación en Vizcaya, las familias querían recuperar a sus hijos.

Pedía Antoniutti a los nuncios en Francia, Bélgica, Holanda, Suiza y al arzobispo de Westminster que preguntasen y recogiesen información sobre la resi-

123 6/37 Ildebrando Antoniutti-Pacelli, 8 agosto 1937, ASV Nunz.Madrid 968 209-210.

124 Ildebrando Antoniutti-Pacelli, 5 agosto 1937, copia, ASV Nunz.Madrid 976 568-671.

125 Ildebrando Antoniutti-Pacelli, Bilbao 17 septiembre 1937, ibidem. 566-567. Las conversaciones con los embajadores de Francia, Bélgica e Inglaterra en Hendaya el 28 de agosto. Habló también con el obispo de Bayona, Antoniutti-Pacelli, 30 agosto, ibidem 577-582.

Hispania Sacra, LXI

124, julio-diciembre 2009, 691-753, ISSN: 0018-215-X 
dencia de los niños vascos ${ }^{126}$. Para los que hubieran quedado huérfanos, lo previsto era establecerlos en instituciones adecuadas. El delegado aseguraba que, en Vizcaya y en el resto de las provincias controladas por los nacionales, la vida religiosa era normal, incluso con fervor. En todas partes, había calma, orden y cierta prosperidad ${ }^{127}$.

El ejército vasco se rindió a los italianos, Habían estado negociando mucho tiempo. En dos ocasiones faltaron a sus promesas, cuando parecía mejorar la situación en Madrid, cercada por Franco. Lo hicieron fue un día más tarde que lo pactado. Todos esos hechos irritaron a los mandos nacionales. La Santa Sede negoció a favor de los vascos. Las buenas condiciones, aceptadas por Franco, fueron rechazadas por ellos.

Entre los presos vascos había dos categorías: los soldados y los oficiales y los políticos. Los del primer grupo eran enviados a su casa en cuanto se comprobaba que no habían cometido crímenes, ni participado en incendios, robos y otros actos criminales. Ildebrando Antoniutti estuvo en Laredo y Castro Urdiales. con el segundo grupo. Habló con bastantes. Se quejaban solo de haber sido engañados por sus jefes. Los oficiales presos en Santoña le dijeron que eran tratados bien.

En su respuesta la demanda de clemencia hecha en nombre del Papa, Franco dijo que la acogía y que estaban siendo generoso con los prisioneros, pero que los responsables de crímenes horrendos serán castigados. En la medida en que van siendo abandonados por los republicanos los territorios bajo su control, las noticias sobre lo que había pasado eran espeluznantes. En el País Vasco fueron asesinados 48 sacerdotes, muchos católicos y varios miles de ciudadanos por ser de derechas y no nacionalistas.

Iban a ser juzgados los autores de hechos criminales y los que eran sus jefes. Antoniutti testifica lo que ha oído en sus visitas a las regiones devastadas. En un texto tachado en la minuta, para que Cardenal Pacelli pueda entender la magnitud de estos horrores, recuerda los actos de los alemanes durante su ocupación de Bélgica en la Gran Guerra. Los cometidos en España fueron mucho más abominables ${ }^{128}$.

${ }^{126}$ La intervención de la Bishops' Committee for the Relief of Spanish Distress (Comité de los obispos para aliviar los sufrimientos en España). Presidido por Mgr. Hinsley, arzobispo católico de Westminster, esta Junta cuidó de evacuados de la zona republicana. Michael ALLPERT, «La respuesta inglesa humanitaria y propagandista a la guerra civil española», Revista de Estudios Internacionales 5/1 (1984) 27-38.

127 Copia de esta carta, ASV Nunz.Madrid 976 21-22. El 17 de agosto le respondía el encargado de negocios de la Santa Sede en La Haya, ibidem 441-442. Hay un ejemplar con fecha y bajo el membrete «Commissione Pontificia pel Ritorno dei Fanciulli Baschi», Bilbao 11 agosto 1937, ibidem 486-487.

${ }^{128}$ La respuesta de Franco fue enviada al cardenal Goma, que la transmitió a Ildebrando Antoniutti, Pamplona, 8 septiembre 1937. Responde el 2 de septiembre a una carta del 31 de agosto, indicando que va a hacer la gestión, ASV Nunz.Madrid 974240 y 274. Minuta sin fecha, 241-244. Posiblemente 
El 17 de agosto de 1937 comenzaron las operaciones en Santander. Se había esperado el resultado de las negociaciones con los nacionalistas vascos. Interrumpidas tras la contraofensiva de los republicanos en Madrid, se reanudaron tras la batalla de Brunete. Cuando en la primera semana de agosto los nacionalistas y los rojos hicieron una ofensiva, se rompieron de nuevo las negociaciones. Otro revés para los nacionalistas y nueva demanda de negociación.

Los italianos pidieron que 20 oficiales y 200 soldados quedaran como rehenes. El general Manzini propuso como enlace en Bilbao a Ildebrando Antoniutti, mencionando sus gestiones humanitarias a favor de los presos vascos. En los primeros avances de los italianos varios batallones vascos se rindieron. ¿Podrían cumplir su compromiso los italianos? No les sería fácil.

Terminada la ofensiva, Antoniutti comentó la buena impresión de los vencidos ante el trato humanitario que recibían. Había tres grupos: los encerrados en Santoña y los que estaban en un campo de concentración de Castro Urdiales. Aquí, los nacionalistas vascos en uno, y los republicanos en otro ${ }^{129}$. Fue una derrota colosal por el número de soldados desmovilizados y por los recursos que pasaban a disposición de la zona de Franco. Los intereses de Inglaterra en el norte de España podrían acelerar el que el gobierno inglés reconociese la beligerancia a la España nacional.

Hay tres datos de interés. El primero es conocido. Franco dijo que los vascos no cumplieron su parte de compromiso y que los italianos eran libres para cumplir los suyos. El segundo, la visita de Ildebrando Antoniutti a los presos, oficiales y sacerdotes en Santoña, y al campo de concentración de los vascos. Muchos de los 30 capellanes presos eran personas de cabeza caliente que ni siquiera habían aprendido en la derrota ${ }^{130}$. El tercero, la sublevación en Santander, previa a la llegada de los nacionales e italianos. Eso provocó una dura represión. Cuando se rindió, los familiares de los asesinados esos días pidieron justicia. Visitaban el campo de prisioneros republicanos para señalar a los culpables. Con todo, parecía que en este terreno se estaba imponiendo la moderación ${ }^{131}$.

es una respuesta al cardenal J. E. van Roey, arzobispo de Manila, 15 septiembre 1937, ibidem 245. Parece que la respuesta fue mucho más escueta que la minuta. Se limitó a recordar dos cosas: que los vascos faltaron a sus promesas aceptadas en la negociación con los italianos y que la misma Santa Sede consiguió buenas condiciones para ellos, que Franco recibió bien, pero los vascos las rechazaron.

129 Informe de Ildebrando Antoniutti al cardenal Gomá, 31 agosto, $A G 7307$.

130 Datos sobre los sacerdotes, informe de Antoniutti al cardenal Gomá, 31 agosto, y respuesta, Bilbao 2 septiembre, $A G 7307$ y 327-328.

131 Minuta sn. Antoniutti-Pacelli, Bilbao 17 agosto 1937. Hay dos documentos sin fecha, pero posteriores a la toma de Santander, ASV Nunz.Madrid 968 542-546. Esos mismos días, Azaña escribió sobre uno de los miles de casos de gentes que aprovecharon la guerra para satisfacer sus odios y añadirle más horrores. Azaña-Cipriano de Rivas Cherif, 5 septiembre 1937, Retrato de un desconocido... 695.

Hispania Sacra, LXI

124, julio-diciembre 2009, 691-753, ISSN: 0018-215-X 
Unos 60000 vascos fueron obligados a retirarse de Vizcaya con el ejército rojo. Se culpaban a los sacerdotes y dirigentes nacionalistas de haberles causado tanto sufrimiento para sostener una batalla perdida y de ponerse al lado de los comunistas, enemigos de la religión y de la patria. «È la tragedia di questo povero popolo».

Estuvo Ildebrando Antoniutti en Santander del 1 al 3 de septiembre. Aunque el rápido avance de los nacionales e italianos había ahorrado destrozos, la ciudad estaba sucia y había miseria y desorden. Había sido destruido el barrio residencial, para hacer una Avenida Rusia. Se habían construido refugios antiaéreos, que servían sobre todo para inspeccionar, controla e interrogar a la población.

Fueron torturados unos 3000 presos en el Faro de Santander. Los fusilaron y arrojaron al mar, algunos aún vivos. Sus cadáveres aparecieron en las costas francesas.

Se destruyeron iglesias, imágenes y objetos religiosos. Se dedicaron los templos a otros usos. El culto católico estuvo prohibido. Los sacerdotes fueron perseguidos a muerte. Podían haber sido asesinados unos ochenta sacerdotes diocesanos y otros entre extra-diocesanos y religiosos. Los comunistas no tuvieron tiempo de quemar el seminario de Comillas ${ }^{132}$.

Llevó un Antoniutti un donativo del Papa para los niños refugiados. Dio al obispo más de 50000 ptas. ${ }^{133}$.

Los documentos de José Antonio Aguirre incautados probaban la conexión del clero vasco con los comunistas y con la Iglesia anglicana ${ }^{134}$. Ante el Gobierno vasco solo hubo un representante extranjero: el de Moscú, que, según Antoniutti, controlaba a Aguirre. Un documento acusa al Papa de ser el mayor culpable de la tragedia de España. Se dice que Franco es un agente de Pío XI: querría restablecer, por medio de una inquisición armada, el papismo, falsamente designado como cristianismo ${ }^{135}$.

El cardenal Pacelli avisó inmediatamente a Antoniutti sobre la doble cara del nazismo. En Alemania se perseguía a la Iglesia. Se la criticaba en la prensa. Se hacía burla de sus obispos. En el exterior los agentes nazis se mostraban atentos con ella, tratando de difundir la idea de que en su país la Iglesia era respetada.

Las autoridades eclesiásticas no debían dejarse engañar por los signos de deferencia que recibieran del personal alemán del partido. Los representantes de

132 Una información de lo sucedido en Asturias, según datos recogidos hasta el 30 de noviembre, $A G$ 8, 470-471.

133 Visita a Santander, texto mecanografiado sin número, pero del 3 de septiembre 1937, ASV Nunz.Madrid 969 478-479. Las ayudas canalizadas a través de Antoniutti, ASV Nunz.Madrid 974 2-231.

134 Había una combinación de los rojos y los «demócratas ingleses», con la participación de la Sociedad Bíblica de Madrid, «para llenar la zona roja de misioneros protestantes». Gomá-Pacelli, Pamplona 28 septiembre, $A G 7,583-584$.

135 Transmite esta noticia a título de información, dando a entender que carece de crédito. 8/37 Antoniutti-Pacelli, 18 agosto 1937, ASV Nunz.Madrid 968 531-533. 
la Santa Sede tenían graves deberes de vigilancia en este punto para que se entienda que conocen la verdad y deploran el daño que sistemáticamente se hace a los obispos y a los católicos alemanes ${ }^{136}$.

Antoniutti hizo notar a las autoridades españolas la inquietud con la que la Santa Sede veía la penetración del nazismo en algunos ambientes de la España Nacional. Se había dicho en ellos que el origen del problema religioso no estaba en Alemania, sino en el Vaticano, acusando a Pío XI de ser un aliado de los judíos. La Acción Católica era una organización política. Eso provocará una guerra del fascismo contra este catolicismo politizado ${ }^{137}$. Esto se sostenía después de que Pío XI hubiera denunciado los ataques fascistas contra la Acción Católica ${ }^{138}$.

Una Circular de FET y de las JONS apuntaba: la religión no será ya en España un instrumento de perturbación «en manos populistas, de masones y anormales...Ya es hora de que tengamos una religión de Apóstoles no de abates... No concebimos la diplomacia de la Iglesia, si no está sostenida por esta única cosa: la buena fe».

Se estaba enviando a jóvenes españoles a Alemania y enfermeras, a los hospitales, «donde, como es bien conocido, se practican métodos contrarios a la principios de la moral católica». Se refiere a la esterilización eugenésica.

Pese a eso, Antoniutti no duda de las autoridades a las que califica de «óptimas», porque creía que aún estaban a tiempo de evitar todo lo que se opusiera a la «verdadera restauración religiosa de España en un sentido tradicionalmente católico»139.

Comentó con Franco los errores nazis en conversación privada. Lo hizo con prudencia. Habló también en San Sebastián con José Antonio de Sangróniz sobre este tema y el resto de los asuntos tratados días antes en Salamanca ${ }^{140}$.

${ }^{136}$ La Mit Brennender Sorge no fue publicada en España. El cardenal Goma iba a dar instrucciones a los obispos para que lo hicieran en los Boletines Eclesiásticos no sometidos a censura. La publicó $R a$ zón y Fe. Antoniutti-Pacelli, 8 febrero 1938, ASV Nunz.Madrid 973 365-366.

137 Sobre este asunto, informó Isidro Gomá. Hay un extenso documento, de junio de 1937, que se envía junto con otro relativo a El Debate, Gomá-Pacelli, Pamplona 7 septiembre, AG 7, 370-373 y 6 , 607-628. ASV Affari.Ecclesiastici Spagna IV 794, 166, 4-6. Como nexos se envían comentarios que acusan a los dirigentes de la Acción Católica y de la ACNP y una prueba documental, ibidem 8-41.

138 «De todo cuanto hemos expuesto, sobre todo de los acontecimientos mismos tal como se han desarrollado, resulta que la actividad política de la Acción Católica, la hostilidad abierta o enmascarada de algunos de sus sectores contra el régimen y el partido, así como también el refugio eventual que constituye la Acción Católica para adversarios del fascismo, desorganizados hasta hoy día, no son más que un pretexto o una acumulación de pretextos; más aún Nos atrevemos a decir que la misma Acción Católica es un pretexto; lo que se ha querido hacer ha sido arrancar de la Iglesia la juventud, toda la juventud». (Pío XI, Non abbiamo bisogno, 29 junio 1931, n. 21).

139 Riservata 3117/37 Cardenal Pacelli-Ildebrando Antoniutti, 6 agosto 1937. Lo que parece una minuta de nota verbal al Gobierno, está sin fecha, ASV Nunz.Madrid 973 316-319.

140 3319/37 cardenal Pacelli-Ildebrando Antoniutti 15 agosto 1937 e Ildebrando Antoniutti-carde-

Hispania Sacra, LXI

124, julio-diciembre 2009, 691-753, ISSN: 0018-215-X 
Aun considerando «pasajera» la situación, alarmó al cardenal Pacelli la orientación laicista que se notaba en algunas decisiones de las autoridades de Burgos, citando expresamente «Auxilio Social». Nada se preveía sobre la educación religiosa y moral de los niños acogidos ${ }^{141}$.

Las circunstancias hacían que las relaciones con el «Gobierno de Burgos» se mantuvieran bajo mínimos. El acercamiento fue por vía humanitaria y a favor de los vascos, durante el asedio en Bilbao. La Santa Sede abogó a favor de los dirigentes nacionalistas para evitarles humillaciones y salvar sus vidas, pues eran católicos y habían asegurado el culto durante los meses de su mandato.

Hubo que salvar las vidas de religiosos condenados a muerte y tratar de restaurar las fracturas dentro de algunas órdenes. Tras rendirse Bilbao, fueron sometidos a consejo de guerra sumarísimo nueve padres carmelitas. El 3 de agosto escriben desde el Carmelo de Begoña al Definitorio Provincial. Cuentan su defensa ante el tribunal el 30 de julio. Denuncian a otros carmelitas, que los acusaron con «violencia y exageración». Mencionan a quienes hicieron declaraciones muy «exageradas e injustas» ${ }^{142}$.

En su informe de la visita, el P. Silverio de Santa Teresa afirma que dos tercios de los carmelitas de la Provincia son nacionalistas, según declaraciones hechas ante él por los frailes. Una cuarta parte, «ex activis propugnatoribus dicti Nationalismi», entre los otros carmelitas y entre los seglares. Era una situación

nal Pacelli, 18 agosto, ASV Nunz.Madrid 968523 y 536. Informaciones de prensa ibidem 425-517. Hay unas notas que recogen la impresión de Ildebrando Antoniutti de su encuentro con Franco. En ellas se expresa de forma más clara lo tratado sobre las teorías raciales de los nazis, ibidem. 258-259.

141 Pacelli-Gomá, 21 julio 1937, AG 6, 528-529. Se anunciaba la aceptación de Pablo de Churruca, Marqués de Aycenena, como encargado de negocios, hasta ese momento representante oficioso. El cardenal Gomá lo transmitió a Franco. Isidro Gomá-Franco, Toledo 1 agosto 1937, AG 7, 18-19. María Luisa Rodríguez AISA, El cardenal Gomá... 466-467. Antonio MARQUINA, La diplomacia vaticana... 351-352. Acuse de recibo, Federico Oliván-Isidro Gomá, 13 agosto, ibidem 356.

142 «Vimos con mucho sentimiento que la mayoría de las acusaciones, quizás las más graves, y algunas hasta calumniosas que se acumularon en el juicio contra nosotros, partían de nuestros Hermanos en Religión, sacando a pública luz cosas íntimas de nuestra vida religiosa, con harto escándalo para el público y no pequeño descrédito para nuestra Provincia». Apéndice documental en Julen UUKIZA, «La Provincia Carmelitana de "San Joaquín de Navarra" durante el decenio de los años treinta», en Cuestión religiosa y democracia republicana en España (1931-1939), Javier DRONDA y Emilio MAJUELO (coord) Universidad Pública de Navarra, 2007, 338-344. En el Carmelo de Begoña cumplieron condena otros sacerdotes. Carta del P. Silverio de Santa Teresa al marqués de Aycinema, encargado de negocios ante la Santa Sede, 20 abril 1938. Reconoce el papel de la resistencia vasca en la prolongación de la guerra, ibidem 149-150. Para los capuchinos, José Ángel EchEVERRÍA, «Los capuchinos de NavarraCantabria-Aragón en los años treinta (I) y (II)», Scriptorium Victoriense, 55/1-2 y 55/3-4 (2008)101195 y 3 261-534, donde incluye un extenso apéndice documental. Puede verse asimismo su colaboración en el libro coordinado por Javier Dronda y Emilio Majuelo, «Los capuchinos de Navarra-Cantabria-Aragón en los años treinta», o. c. 145-296. 
generalizada $^{143}$. No era previsible que rectificaran. Muchos de ellos deseaban la derrota de los enemigos del nacionalismo ${ }^{144}$. Para remediar estos males no bastaban las medidas disciplinares. Los Había exhortado «ad concordiam et mutuam caritatem», pues, sin ellas, no es posible que los religiosos se santifiquen y puedan trabajar por la salvación de los otros ${ }^{145}$. Muy poco debió conseguirse, si damos fe al testimonio del visitador el 20 de abril de $1938^{146}$.

\section{LUCHA DE IDEAS: LEGITIMIDAD Y SIGNIFICADO DE LA GUERRA}

Volvamos al documento colectivo. Salió con retraso. Hubo que preparar la traducción al francés y al inglés. Recordó el cardenal Gomá que iba dirigido a los obispos extranjeros. La cortesía exigía que primero llegara a sus destinatarios. A ellos se dirigió el 20 de julio. En esta carta, escrita en latín, recordaba que había una lucha de ideas. Se debatía, por tanto, sobre la legitimidad y el significado de la guerra ${ }^{147}$. En ese combate se consideraba honesto acomodar

143 «Sub hoc aspectu Ordo noster, sicut multi alii Instituti Religiosi, suam aestimationem inter catholicos amiserunt et habentur ut inimici Hispaniae». Los conventos de los que se tenía esa opinión eran Begoña, Larrea, Amorebieta, Marquina y San Sebastián.

${ }^{144}$ Esta postura resalta más, después de la pastoral colectiva de los obispos y cuando se conocía la persecución contra el clero en la zona republicana y la supresión del culto público. El visitador lamenta que no perciban estos carmelitas que un triunfo del «bolchevismo» supondría la pérdida de la libertad política y el extermino de la Iglesia «sicut in caeteris regionibus».

145 Entre los mandatos del visitador: que los superiores fomenten con la debida prudencia el amor a la Patria, España, dado que esto no obsta para amar la propia región. Por lo demás, silencio sobre el separatismo y el nacionalismo vasco. Porque este fue el problema que originó la visita, tras una comunicación del cardenal Pacelli al Padre General de la Orden. El informe, texto latino, firmado en Burgos el 15 de octubre de 1937, ibidem 345-348. La otra visión, en el documento que los Padres José Antonio de la Purificación, Plácido de Santa Teresa y Leoncio de San Juan de la Cruz remiten al P, Tomás de la Virgen del Carmen, superior general, desde Agen el 27 de junio de 1938, texto español traducido del original en latín, Julen Urkiza, «La Provincia Carmelitana... 357-364.

146 El P. Modesto de la Virgen del Carmen, colaborador de la Semana Internacional, editado en Valparaíso (Chile), censuraba la represión de requetés y falangistas en este tono: «Cadáveres necesitan... carne fresca de juventudes para saciar su criminal sadismo», Julen URKIZA, «La Provincia Carmelitana...» 352. Es el mismo vocabulario degradante utilizado por las organizaciones que perseguían a los católicos.

147 Exiliado, José Castillejo Duarte publicó en1937 su Wars of Ideas in Spain y que no tuvo demasiada difusión. Edición en español, Guerra de ideas en España:filosofía, política y educación, prólogo de Julio Caro Baroja, introducción por Michael E.Sadler, Madrid,Revista de Occidente, 1976. El volumen con sus cartas que llega hasta este año tiene un título muy significativo. El epistolario de José Castillejo:los intelectuales reformadores de España, 3 Fatalidad y porvenir: 1913-1937, cartas reunidas por David Castillejo, Madrid, Castalia, 1999. Vid. Luis PALACIo BAÑUElos, José Castillejo. Última etapa de la Institución Libre de Enseñanza, Madrid, Narcea, 1979), y Castillejo, educador, Ciudad Real, 1986, El Instituto-Escuela. Historia de una realidad educativa, Madrid, Ministerio de Educación, 1988, «José Castillejo, una vida dedicada a hacer realidad la España deseada de la ILE» en Elias

Hispania Sacra, LXI

124, julio-diciembre 2009, 691-753, ISSN: 0018-215-X 
los hechos para justificar la propia postura ${ }^{148}$. Por esta razón habían decidido los obispos publicar el documento. Era su explicación del significado de los sucesos españoles. La hacían porque hasta la prensa católica extranjera no los entiende y los desfigura ${ }^{149}$.

No exponían una tesis. Relataban los hechos que configuran históricamente la guerra (n 2). Desde 1931, los obispos fueron leales a la República. La acataron incluso cuando los poderes públicos no tutelaron los derechos e intereses de la Iglesia. Sus protestas fueron razonadas. En todo momento exhortaron a los católicos a colaborar con el poder constituido en beneficio del bien común. «La Iglesia no ha querido esta guerra ni la buscó». Hablaban ahora porque uno de los beligerantes «iba a la eliminación de la religión católica en España» (n. 3).

La responsabilidad es sobre todo de quienes no gobernaron la nación «según la justicia». Los desórdenes públicos, la impunidad de quienes los promovían, derivaron, tras las elecciones de febrero de 1936, hacia la revolución. Los asesinatos de eclesiásticos y de religiosas y religiosos no fueron consecuencia del «alzamiento militar». Los habían decidido antes los revolucionarios (n. 4). El alzamiento fue una «ultima ratio», tras desatender el poder civil los avisos que le dieron los militares. A estos se unieron otros sectores civiles.

«La guerra es, pues, como un plebiscito armado» para salvar o destruir «el viejo espíritu español y cristiano». La Iglesia estaba obligada a tomar posición ${ }^{150}$. $\mathrm{Al}$ hacerlo, no se solidarizaba con lo que pudiera desnaturalizar «esa noble fisonomía». En su dimensión patriótica y religiosa hallaba fuerza y arraigo popular el movimiento militar de julio. Su victoria es el único modo de «reconquistar la justicia y la paz y los bienes que de ella derivan». Para concluir esto bastaba mirar los rasgos de «la revolución comunista» y sus frutos. Pese los daños sufridos, las ofensa recibidas, las víctimas de la persecución, tiene la Iglesia «una palabra de perdón para todos» y el propósito de hacer todo el bien posible ${ }^{151}$ (nn. 5 y 6).

Antes de terminar, el documento responde a los «reparos» aparecidos fuera de España. La Iglesia no se enfrentó a un movimiento popular, provocando de

Díaz, Luis Palacios, Javier Muguerza, Javier SÁDABA, Educación y universidad, Madrid, Fundación Ramón Areces, 2005, 47-83 y «José Castillejo Duarte», Circunstancia 14 (2007) http://www.ortegaygasset.edu/contenidos.asp?id_d=220.

148 «Nuestro país sufre un trastorno profundo». No es sólo una guerra civil «cruentísima», es «una conmoción tremenda que sacude los mimos cimientos de la vida social y ha puesto en peligro hasta nuestra existencia como nación» (n. 1).

149 Carta a los obispos españoles y a los obispos extranjeros, 20 julio 1937, $A G$ 6, 514-516.

${ }^{150}$ Los obispos explican la razón. Resumen los rasgos que dan fisonomía a cada uno de los bandos: los que quieren una revolución comunista y los que luchan por la patria y por Dios (nn. 6 y 7).

151 «Dios sabe que amamos en las entrañas de Cristo y perdonamos de todo corazón a cuantos sin saber lo que hacían, han inferido daño gravísimo a la Iglesia y a la Patria. Son hijos nuestros... Rogad, pues, para que en nuestro país se extingan los odios» (n. 9). 
ese modo las destrucciones de templos, cosas sagradas y el asesinato del clero y de los fieles. No era la Iglesia de 1931 la Iglesia del antiguo régimen. Había perdido todos sus bienes ${ }^{152}$.

La Iglesia no eligió campo. Debía estar al lado de la justicia y de la paz. Por eso había podido colaborar siempre con todos los poderes del Estado, buscando el bien común. El documento reconoce que se había iniciado en los años anteriores un camino para una mejor distribución de la riqueza. No puede decirse, pues, que se trata de una guerra de ricos contra pobres ${ }^{153}$. No era una guerra entre la democracia y el totalitarismo ${ }^{154}$. Puede afirmarse que «no se ha emprendido para levantar un Estado autócrata sobre una nación humillada, sino para que resurja el espíritu nacional con la pujanza y libertad cristiana de los viejos tiempos». Si no fuera así, se quebraría «la trayectoria espiritual del país». Sería un gran error, pero no es de esperar que se cometa.

No podían equipararse las represalias en uno y otro bando.

Al referirse a los nacionalistas vascos, el documento cita la Divini Redemptoris, recordando la responsabilidad que tiene la división de los católicos en el ascenso del comunismo. Siendo este intrínsecamente perverso, es mucho más devastador en las naciones que se han distinguido por la grandeza y antigüedad de su civilización cristiana» (n. 8)

El texto, dice Rodríguez Aisa, tuvo un tono marcadamente apologético y asertivo. Vidal i Barraquer se opuso. No entró en el su contenido. No lo juzgaba oportuno. No debía aceptarse injerencias extrañas. Mateo Múgica no lo hizo, porque juzgó su deber abstenerse, estando ausente de su diócesis.

El documento sirvió a los nacionales para legitimar con un contenido religioso de lo que lo que desde el primer momento se consideró «una cruzada» 155 .

152 Además de la expropiación hecha en el siglo XIX, la Ley de Confesiones y Congregaciones religiosas la privó de cualquier financiación que no procediera de sus fieles.

${ }^{153}$ Sobre la vinculación del clero con los ricos y su alejamiento de los pobres, el documento responde señalando la procedencia social de los 7401 seminaristas que había en 1935 y recordando que los pobres no están obligados a dar dinero por los servicios religiosos que solicitan y reciben.

${ }^{154} \mathrm{La}$ creación del antifascismo como polo antagónico de la democracia en los años veinte y antes de la II Guerra Mundial, en François Furet, El pasado de una ilusión. Ensayo sobre la idea comunista en el siglo XX, México, Fondo de Cultura Económica, 1995, 296-306 y 339. La incapacidad de la izquierda, la nacida después de mayo del 1968, para analizar el socialismo real y abandonar sus mitos e iconos, ibidem 561.

${ }^{155}$ La alocución «Con inmenso Gozo» de Pío XII, abril 1939, prevista y preparada semanas antes, ratificó el mensaje central de la Carta Colectiva: la existencia de persecución religiosa, contra las personas y contra las cosas y lugares sagrados, con el designio de acabar con el cristianismo y con la Iglesia, María Luisa RodríGuEz AisA, El cardenal Gomá... 348-351.

Hispania Sacra, LXI

124, julio-diciembre 2009, 691-753, ISSN: 0018-215-X 
Es lamentable que sus adversarios, también sus herederos, hayan dado por válida esa interpretación y ese uso durante años, sin darse cuenta de ello, porque aceptan lo que desconocen. Decir lo que dicen los del otro para negarlo es replicar, pero eso no restablece la verdad. La más antigua acepción de esta palabra es «repetir lo que se ha dicho» ${ }^{156}$.

Es evidente que ese uso no invalida el argumento central de la carta: que la Iglesia estaba perseguida y había deseos de exterminarla. José María Torrent, oratoriano, vicario general de Barcelona, pidió al cónsul suizo en la ciudad que se interesara por la suerte de 600 religiosos detenidos, después de haber sido absueltos. Permanecían en la cárcel por decisión del Govern de Catalunya ${ }^{157}$.

Torrent informaba sobre la situación de la diócesis: no había ni una iglesia, ni una capilla, ni un oratorio privado en toda Cataluña. Muchas de las iglesias incendiadas en los primeros días, fueron después destruidas por mandato de los comités revolucionarios o por orden de la autoridad civil.

El obispo, Manuel Irurita, fue detenido no por la policía, sino por una «patrulla revolucionaria». Desde el 1 de diciembre estaba desaparecido en «una cárcel clandestina»158. Aseguraban que estaba vivo ${ }^{159}$. Por cierto que Torrent habla de la zona bajo el control de Franco como «la España libre» 160 .

156 Acepción cuarta, Diccionario de la Real Academia de la Lengua, $22^{\text {a }}$ edición.

1572615 Aldo Laghi, encargado de negocios, a Pizzardo, 11 agosto 1937, ASV Affari.Ecclesiastici Spagna IV 891, 271, 28.

«...raro es el sacerdote o religioso a quien se la haya concedido la libertad, no obstante ser decretada por los tribunales», Torrent-Pacelli, 18 octubre 1937, ibidem. 69. Cuando no se concedió la libertad a los presos gubernativos, quedaron en las cárceles sólo los sacerdotes y religiosos que sufren condenan o estaban a la espera de juicio, Torrent-Pacelli, 26 noviembre, ASV Affari.Ecclesiastici Spagna IV $891,271,82$.

158 Hay una leyenda sobre Irurita. Dicen haberlo visto vivo por el claustro de la catedral de Barcelona al acabar la guerra. En abril de 1939 habló Azaña con una comisión de nacionalistas sobre algunos aspectos de la guerra en Barcelona. Uno de ellos, la suerte de Irurita. No se sabía si había sido asesinado. Un nacionalista catalán, dijo: «No. Seguramente no le han asesinado. El señor Obispo no merecía el martirio». Manuel Azaña, Causas de la guerra... 122. El texto en cursiva es de Azaña. La noticia de su asesinato, denunciado en términos jurídicamente rigurosos, se recoge en Mateo MADRIDEJOS, Diccionario onomástico de la guerra civil, Barcelona, Flor del Viento Ediciones, 2006, 170.

${ }^{159}$ El 8 de septiembre la Secretaría General de Franco comunicó al cardenal Gomá: «En los ambientes rojos de París se confirma con insistencia el asesinato del Obispo de Barcelona, Dr. Irurita», $A G$ 7, 390. Hubo un desmentido, que el cardenal Gomá se apresuró a transmitir al cardenal Pacelli el 25 de septiembre. La noticia procedía del presidente de la Cruz Roja Española. ¿Dónde estaba el obispo? Isidro Gomá dice: «únicamente conocen su actual paradero los Señores Irujo, Nicolás d'Olwer y el Rdo. Pablo Rovira, Párroco de San Pablo del Campo, de Barcelona», AG 7, 564.

160 Torrent-Pizzardo, 26 julio 1937. En una carta del 18 de octubre decía al cardenal Pacelli que nada se sabía del obispo Irurita, ASV Affari.Ecclesiastici Spagna IV 891, 271, 30-36 y 68. 
Al poco tiempo de la publicación de la Carta Colectiva del Episcopado, Azaña comenta que la Iglesia había participado en esta guerra como «en una cruzada contra infieles». Fue su error. Aunque hubiera sido injustamente perseguida, su papel no era ese. »La religión no se defiende tomando las armas e incitando a los demás a que las empuñen». Echaba en falta, catorce meses después de iniciarse la guerra, el que al menos un obispo hubiese pronunciado «las palabras de paz, de caridad, de perdón que les corresponde decir, si de verdad su reino no es de este mundo». En el verano de 1940, antes de salir de Arcachon hacia Montauban, mantenía aún esa dura opinión «Lo que ha hecho en España la Iglesia católica no tiene perdón de Dios». Quedaba la amenaza de «un estrago mucho mayor». Si eso volviera a producirse, esta vez sí que la gente «tendrá lo que no ha tenido ahora: razón»161.

Hace Azaña una sutil mezcla principios éticos, que obligan a los otros, pero no a los nuestros, que usa la imagen más que la razón. Deja así abierta la vía de la revancha. Otorga una exculpación retroactiva a la persecución sufrida por la Iglesia. Pasa por alto los efectos de la violencia, que será lícita en el futuro. Olvida que, rota la convivencia en paz, los inocentes son las primeras víctimas. Para asesinarlos hay que reducirlos primero a meros símbolos, desnudarlos de su condición humana. Su eliminación es un ritual presente en toda revolución. Omite Azaña la destrucción del patrimonio cultural por esa violencia sin freno, pero lícita para sus autores, y que hace lícita a de quienes la castiguen...

En el contexto de las reacciones ante la pastoral colectiva, había que destacar conducta de los obispos españoles, respetuosos desde el primer momento con la República, siguiendo las instrucciones de la Santa Sede. Esa actitud se mantuvo a lo largo de los años que preceden a la guerra civil.

El Papa nombró un nuevo nuncio a Filippo Cortesi, que no pudo incorporarse. Un encargado de negocios permaneció en la nunciatura los meses siguientes al 18 de julio.

La implicación de la Iglesia en el conflicto no fue querida por ella. «Se oggi il clero di Spagna è costretto ad assumere un attegiamento inequivocabile, ciò si deve nzitutto all'interferenza inevitabile del conflitto a caracttere politico e sociale, nel campo religioso e poi alle manovre tendenziose di inividuati ambienti stranieri, che tentano di presentare sotto una luce falsa l'attegiameno dei vescovi di Spagna, i quali, secondo i «rossi», accecati da furore di parte, avrebbero costretto il remanente clero a seguirli in senso favorevole al movimento nazionale, senza caire che, insconciamente, fanno il igiuoco dei Regimi assorbenti e totalitari, rischiando di asservire el futuro l'ordie spirituale della Chiesa all'in-

161 Cipriano de Rivas CHERIF, Retrato de un desconocido... 483.

Hispania Sacra, LXI

124, julio-diciembre 2009, 691-753, ISSN: 0018-215-X 
transigenza di uno Stato Fascista. Ormai, la Chiesa no cederà mai sul principio dell'independenza necessaria all'esercizio del suo ministero» 162 .

El 7 de septiembre de 1937 el cardenal Jean Verdier, arzobispo de París, escribió al cardenal Gomá. La carta colectiva expone con claridad las causas que han llevado a la guerra civil. Aporta luz a otras naciones, mostrando cómo el ateísmo práctico, la relajación de las costumbres y el desprestigio de la autoridad, por la connivencia de los gobierno con esas doctrinas, tienen esas consecuencias.

Hay en España una lucha titánica entre la civilización cristiana y el comunismo soviético. Estaba en juego el futuro de la Iglesia y la civilización que ella creó durante siglos. España había sido el escenario de la primera batalla.

En medio de una desgracia tan terrible, emergen la figura de los que han sido asesinados por su fe y el arte destruido, conservado durante siglos por la Iglesia.

En el futuro, esta España, «siempre fiel», con la aureola de sus mártires, con el perdón generosamente otorgado a sus verdugos, con la unión de todos sus hijos en la obediencia y en la caridad, con un nuevo orden social, establecido a la luz de las Encíclicas pontificias, con la «gloria inmarcesible», en fin, que le ha merecido tanto heroísmo, emprenderá de nuevo, más bella y más confiada que nunca, el camino de sus gloriosos destinos».

El arzobispo de Westminster destacó también la claridad con que el documento examinaba las causas de la guerra. Los obispos de Inglaterra y Gales habían pedido para que volviese la paz a la «Iglesia perseguida» en España ${ }^{163}$.

Esta guerra civil es más bien una revolución. Se lucha por la defensa de una civilización o por su destrucción. Quienes se han arrepentido dan fe de su engaño. No era aceptable la crítica a la Iglesia en los años inmediatos. Haluchado y trabajado, con escasos medios, para educar a sus fieles, atender a los pobres y a los enfermos. Ha respetado a los poderes constituidos, «trabajando siempre por la paz y la armonía, a favor del bien común». Nadie puede culpar a sus ministros de rebeldía, de agresión o de haber empujado a la guerra. Libre de todo poder, no se deja avasallar por ninguno. La verdad de los hechos es que, amenazada de destrucción por los comunistas en las zonas controladas por ellos, «se acoge a la protección de un poder que, hasta ahora ha garantizado la libertad y los principios fundamentales de la sociedad ordenada».

162 «La Chiesa e la guerra civile in Spagna. L'irrefutabile «mise au point» dell'Episcopato», Corriere Diplomatico e Consolare 348 (30 settembre 1937) 7.

163 «...no podemos menos de horrorizarnos de los asesinatos, de los crueles tormentos y ultrajes sacrílegos que han cometido los perseguidores, nos enorgullecemos también de la constancia victoriosa de aquellos miles de españoles, clérigos, religiosos y seglares, que derramaron su sangre por Cristo Rey y por España». 
Mostraba el cardenal Hinsley la solidaridad en la persecución, en la plegaria, en el sufrimiento por tanta mentira, interpretaciones torcidas, subterfugios. La carta colectiva vencerá la oscuridad sobre lo que estaba pasando en España. Que el sacrificio de los mártires apague los odios. Que todos se dejen unir por el vínculo de la caridad ${ }^{164}$.

El documento comenzó a tener resultados. El episcopado se adhirió a lo que en ella se decía. De ese modo, estaba «efficacemente rovesciando l'edificio di menzogne cha la propaganda settaria a erecto, tacendo, mutilando scritti e fatti, contro la Chiesa»

El diario italiano Corriere della Sera denunció la hipocresía de los católicos alineados en defensa de la República. Criticó algunos de los sacerdotes, en conflicto con sus superiores eclesiásticos. Sus comentarios sobre los hechos y su interpretación se apartaba de la dirección trazada por la Carta Colectiva, al hablar de la guerra y los excesos de los republicanos. No era legítimo el triunfo electoral de la izquierda en 1936. Los votos populares no se tradujeron en escaños para la derecha, que había obtenido más.

En cuanto a la legitimidad de ejercicio, el Gobierno presidido por Azaña, en relación a la Iglesia era evidente que no lo era. La había dejado desprotegida y a merced de quienes quemaron sus edificios, profanaron sus templos ${ }^{165}$, asesinaron a sacerdotes y religiosos y no pudo evitar que la gente creyera cercano un golpe revolucionario, más cerca de la URSS que de la social-democracia europea.

Iniciada la guerra civil, en la zona republicana los católicos fueron martirizados, ejecutados sin juicio, torturados, enterrados sus cuerpos, sin avisar a sus familiares, a quienes, en algunos casos, se les ocultó su muerte ${ }^{166}$. En aquellos días Francis Lindley, un anglicano, calificó de «bestialidad sádica» lo que estaba pasando con los católicos ${ }^{167}$.

164 «Del Cardenal Verdier y del Arzobispo de Westminster al Cardenal-Primado de España», $\mathrm{La}$ Gaceta del Norte, 1 octubre 1937, 1.

165 Sobre este «martirio de las cosas», como lo designó Antonio Montero, vid. un reportaje sobre lo que estaba pasando esos días en Santander. «Mientras organizan misas en Valencia, perpetran en Santander el robo sacrílego mayor del mundo», Hierro, 25 septiembre 1937, 1.

166 El Papa denunció esta persecución y llamó mártires a sus víctimas, «Il contributo della Compagnia di Gesù alla nuova epopea dei confessori della Fede nella Spagna», L'Osservatore Romano 18 luglio $1937,1$.

167 «La partigiana offesiva di Stampa contro la Chiesa nella Spagna in una lettera dei Vescovi irlandesi», L'Osservatore Romano 23 ottobre 1937, «La Spagna cattolica», Corriere della Sera 26 ottobre 1937 , 1. Una descripción de lo que fue la vida en el barco prisión Altuna-Mendi y del asalto a la cárcel de los Ángeles Custodios en Bilbao, «Don Félix de Basozábal», El Pueblo Vasco, 6 enero 1938, 1.

Hispania Sacra, LXI

124, julio-diciembre 2009, 691-753, ISSN: 0018-215-X 


\section{El RECONOCIMIENTO DE FRANCO}

Mientras avanzaba la negociación entre la Santa Sede y Portugal para firmar un nuevo Concordato ${ }^{168}$, se preparaba el reconocimiento de Franco. El cardenal Gomá y Pablo de Churruca dejarían de ser agentes oficiosos. Churruca y Antoniutti fueron nombrados encargados de negocios. Era lo previsto ${ }^{169}$. Isidro Gomá quiso urgir ese paso. Se había equivocado la censura, orientando esa campaña contra al Santa Sede. No era necesaria y disgustó en el Vaticano ${ }^{170}$. A los pocos días, había cambiado el clima ${ }^{171}$. Se abría una etapa de confianza y cautela ${ }^{172}$.

Tras presentar sus credenciales ante el cardenal Pacelli, Pablo de Churruca fue recibido en audiencia por Pío XI en Castegandolfo. El Papa le mostró su preocupación por los niños españoles expatriados. Estaba dispuesto a ayudar, hasta el límite de sus recursos, para conseguir su retorno ${ }^{173}$.

El cardenal Gomá informó a Franco que la Santa Sede, le había transmitido el 7 de septiembre que, acogiendo las comunicaciones del marqués de Aycenena, Pablo Churruca, pidiendo un representante suyo ante el Gobierno de Bur-

168 La relazione presentada a la sesión de la S.C. defli Affari Eccleiastici Straordinari 1377, 9 de agosto 1937, impresa, y el «Sommario» para la misma con el texto del Concordato, ASV Affari.Ecclesiastici Portogallo IV 398, 158, 72, 24 páginas y folios 73-74 2 sumarios, 13 y 15 páginas. Informe de Mgr. Colonna, sin fecha, texto mecanografiado y manuscrito, ibidem 75-98. Tc 40 y 1626 Pietro Ciriaci-Pacelli, 16 julio 1937, ibidem 158, 5-6 y 14-25. Las dos partes habían expuesto sus puntos de vista. El de la Santa Sede, ajustado al Código de Derecho Canónico. «Non si tratta tutavia di questione sostanziale», 3361/37 Pacelli-Pietro Ciriaci, 30 agosto, ibidem 192-193 La respuesta del nuncio, 1689/, 6 septiembre, ibidem 220-226. 3214/37 Pacelli-Pietro Ciriaci, 11 agosto, ibidem 144-145. la buena marcha de la negociación, 3664/37 cardenal Pacelli-Pietro Ciriaci, 20 septiembre, ibidem 151. Las modificaciones sugeridas por el cardenal las presentó el nuncio al Gobierno portugués, 1724, 23 octubre, ibidem 228-237. Un planteamiento general de las relaciones de Portugal con la Santa Sede desde 1928, Bruno CARoso ReIs, Salazar e o Vaticano, Lisboa, Instituto de Ciências Sociais da Universidade de Lisboa, 2006, 87-192. Obviamente no pudo consultar los archivos de la Santa Sede, pero sí el de Oliveira Salazar.

169 Pacelli-Gomá, 21 julio y Gomá-Pacelli, Toledo, 1 agosto 1937, AG 6, 528-529 y 7, 13-15.

170 Gomá-Pacelli, Toledo 7 agosto y Pacelli-Gomá, 23 agosto, AG 7, 47-50 y 223-224

171 Su secretario general envió al cardenal Gomá un expresivo telegrama en que afirmaba que FET y de las JONS era el pueblo español, era «eminentemente católica y romana y lucha por los principios católicos de justicia social que inspiraron los documentos sociales pontificios». Gomá-Pacelli, Pamplona 1 septiembre, $A G 7$ 315-318. El Papa aprobaba a nueva orientación más favorable a la Iglesia. Pacelli-Gomá, 14 septiembre, ibidem. 437.

172 «Confiamos en Dios en que, cuando haya de organizarse definitivamente el Estado español, lo será según las exigencias de nuestra tradición cristiana». Que la victoria traiga «una paz cristiana y fecunda». Comentando el éxito de la Carta Colectiva, dice que la situación en España había mejorado para la Iglesia tras el reconocimiento de la Santa Sede, Gomá-P. Wlodomiro Ledokowski, Pamplona 3 septiembre, $A G$ 7, 335-336.

173 Antonio MARQUINA, La diplomacia vaticana... 356-357. Sobre la misión humanitaria de Ildebrando Antoniutti, Vicente CÁrCEL OrTí, Pío XI entre la República y Franco... 306-324. 
gos, había designado a Ildebrando Antoniutti, arzobispo de Sinnada, de Frigia $^{174}$. La propuesta fue bien acogida ${ }^{175}$. Venía de la Secretaría de Estado, como solía hacerse cuando se trataba de un «encargado de negocios»176. El mejor sitio para fijar su residencia era Burgos ${ }^{177}$. Esta nueva misión prolongar lo que Ildebrando Antoniutti creyó que sería una estancia breve. Ni siquiera había traído ropa de invierno cuando viajó a España en julio ${ }^{178}$. Ahora había cambiado su posición oficial y Javier Lauzurica, obispo auxiliar de Valencia, era administrador apostólico de Vitoria desde el 14 de septiembre ${ }^{179}$.

Había varios asuntos pendientes en su misión humanitaria como delegado apostólico. La de los prisioneros nacionalistas estaba casi resuelta. La situación de los sacerdotes detenidos había mejorado. La oficina para la repatriación de los niños vascos podía marchar sin su presencia ${ }^{180}$.

L'Osservatore Romano informaba el 27 octubre de 1937 de la intervención de Javier Lauzurica para repatriar a los niños vascos. El administrador apostólico unía su voz a las de los padres y trataba de suplir la de aquellos que habían olvidado sus deberes hacia sus hijos. Mencionaba la solidaridad del Episcopado en Bélgica, Francia Inglaterra Suiza. Todos habían hecho lo que

174 Pacelli-Gomá y Gomá-Franco, Vaticano 7 de septiembre y Toledo 13 septiembre 1937, AG 7 , 380 y 468. Respuesta de Federico Oliván, 20 septiembre, ibidem. 490-491. María Luisa RoDRÍGUEZ AISA, El cardenal Gomá... 468-469. Antonio MARQUINA, La diplomacia vaticana... 360.

175 Isidro Gomá-Franco, 18 septiembre 1937, y Federico Oliván-Isidro Gomá, 20 septiembre, $A G$ 7, 490 y copia en ASV Nunz.Madrid 968216 y 217-218 Se comunicó el plácet, cardenal Gomá-cardenal Pacelli, 18 septiembre, $A G$ 7, 467. la respuesta oficial del Gobierno.

176 Minuta mecanografiada de la presentación oficial, copia. Con ello se nivelaba la representación con la de Pablo Churruca, 164267 Pacelli-Antoniutti, 23 septiembre, ibidem. 219 y 220 y Gomá-Pace1li, 23 septiembre, $A G$ 7,525-526 y Gomá-Antoniutti, 24 septiembre 547-548.

177 Sabemos que Ildebrando Antoniutti tuvo que insistir para que le autorizaran a vivir en Bilbao. Pacelli le dijo que insistiera en esa condición para poder cumplir su misión. Eso hace pensar que en ella estaba incluida 1 solución de los problemas que Ildebrando Antoniutti acaba de enumerar. Tc 6 agosto 1937, ASV Nunz.Madrid 968327.

178 Risposta al 164267 Ildebrando Antoniutti-cardenal Pacelli, Bilbao 3 octubre 1937, ibidem. 222223.

179 La dimisión de Mateo Múgica la publicó L'Osservatore Romano 13 de octubre. Si la fecha del 14 de septiembre dada en DHEE, IV 1975 2776, no es equivocada, entonces habrá que ver cómo se negoció la dimisión de Mateo Múgica. Este se estableció en Bélgica. Minuta nota Ildebrando Antoniutti al gobierno de Franco, 12 octubre, ibidem. El 4 de septiembre el cardenal Gomá informó al cardenal Pacelli sobre las filtraciones de datos y noticias a quienes luego acataban la autoridad episcopal. Carta del de septiembre, y documento anexo, 7 339-34343. El contexto en Gonzalo REDONDO, Historia de la Iglesia en España... 152-153. Establecido en Bélgica, Mateo Múgica pidió su hermano Celedonio que dijera al cardenal Gomá que no había proporcionado los datos a Ángel Zumeta, a quien no conocía, $A G$ 7, 498. La respuesta del cardenal Gomá, Pamplona 24 septiembre, $A G$ 7, 545.

180 Escribió Ildebrando Antoniutti al cardenal arzobispo de Malinas y pidió a Javier Lauzurica que redactara una especie de llamamiento para contrarrestar la propaganda de los vascos exiliados contra el retorno a los niños. Antoniutti-Gomá, 29 septiembre, $A G$ 7, 591-594.

Hispania Sacra, LXI

124, julio-diciembre 2009, 691-753, ISSN: 0018-215-X 
podían para asegurar instrucción y una vida decorosa a los que estaban fuera de su país ${ }^{181}$. El 22 de febrero de 1938 se habían repatriado más de tres mil niños ${ }^{182}$.

Las reclamaciones en Francia han sido 4000, porque al principio el gobierno francés aceptaba reclamaciones de niños, en paradero desconocido. Luego sólo las de niños con domicilio y dirección exacta ${ }^{183}$.

Hubo 520 reclamaciones a Rusia. Fue al principio de funcionar el secretariado. Un ex miembro del Gobierno Vasco había prometido a los sacerdotes belgas repatriar a los reclamados por sus padres. Se enviaron a Bélgica y se entregaron a este señor, «que no logró» repatriar ni un niño. Desde entonces se dejó de extender reclamaciones, «a pesar de los deseos de los padres» ${ }^{184}$.

Había una colonia para niños vascos, abierta en Bilbao bajo la presidencia de Antoniutti ${ }^{185}$. Fue este el objetivo de su presencia allí186.

A Inglaterra fueron enviados 4152 niños ${ }^{187}$. Trabajaron con el P. Enrique Gábana ${ }^{188}$ Holman Gregory, Theobald Mathew y Riohad R. Ludlow. Fue muy activo el arzobispo de Westminster. Decían contar con el apoyo de José Antonio de Sangróniz. Debían ser repatriados 500 niños. Hubo 387 peticiones. 139 firmadas por los padres; 90 por el padre, 64 por la madre, 14 por la madre viuda;

181 «Una Circolare di Mons. Saverio Lauzurica, Amministratore Apostolico di Vitoria per il rimpatrio dei fanciulli Baschi», L'Osservatore Romano 27 ottobre 1937, 1. Hay una traducción italiana de la Circular, ASV NM 976 521-524.

182 Monseñor Antoniutti habla para los lectores de Voluntad, Voluntad 22 febrero 1938, 4.

183 Lista completa de los 3915 niños repatriados, con su edad, ASV Nunz.Madrid 977 V 521-593. La información sobre la labor en Francia, Bélgica, Inglaterra y Suiza, ibidem 975. 2-203, 205-415 y 416-484.

184 Ibidem 975415.

185 Bilbao 30 septiembre 1937 , ibidem 475.

186 «La Tragedia de los niños españoles», Heraldo de Aragón 29 julio 1937, 6. «La tragique vérité sur l'exode des enfants Basques. La mission du délégué du Pape à Bilbao conclut à l'opportunité de leur repatriament», La Métropole, 25 août 1937. Este diario se editaba en Amberes. «La repatriación de los niños vascos. Pronto ha de llegar la primera expedición. Los comités procuran dificultar la labor. Cómo se envenenan las conciencias juveniles. Todos los padres y familiares deben colaborar con el Secretariado», La Gaceta del Norte 7 septiembre 1937, 1. Paul MCGUIRE «Going Home with the Basque Children», Catholic Herald, november 26, 1937, 2. «Pour le retour des enfants basques dans leurs foyers», La Croix 31 octobre 1937, 1-2.

${ }^{187}$ Lista completa, ASV Nunz.Madrid 977 595-668.

188 Enrique Gábana, de la diócesis de Barcelona estaba en la delegación del Estado para Prensa y Propaganda, en Vizcaya. Fue a Inglaterra en nombre de esta delegación y enviado por Antoniutti. Logró la repatriación de 160 niños, que entraron en España en la mañana del 14 de noviembre de 1937.Crónica de esa jornada, «España rescata a sus hombres del mañana» La Voz de España 11 noviembre 1937, 4. El 28 de noviembre dio una Conferencia en el Teatro Buenos Aires, de Bilbao, relatando la operación y haciendo una crónica del regreso. El informe de la gestión de Gábana, Ildebrando Antoniutti-Sangróniz, Burgos 17 noviembre 1937, ASV Nunz.Madrid 976 I 6-7. 
65 fueron firmadas por uno de los dos; 4 lo fueron por sus tutores, y 11, por otros parientes. Fueron repatriados solo 150 niños ${ }^{189}$.

Las autoridades nacionales lamentaron que el cardenal Lienart, obispo de Lille, pidiera socorros para los refugiados vascos, muchos de ellos «hermanos de fe». Podía hacerse a través del Comité de Bayona para los Refugiados. Esa decisión provocó que otros franceses, amigos de la España de Franco, hicieran campaña contra las iniciativas de algunos de sus obispos, como sucedió en la diócesis de Auch. Se comunicó al cardenal Gomá el 29 de setiembre que ya en julio los comunistas franceses felicitaron al cardenal Jean Verdier, arzobispo de París, por auxiliar a los refugiados. Estaba secundando estas acciones el «Comité Français pour la Paix Civile et Religieuse en Espagne», en el que figuraba Jacques Maritain $^{190}$.

Había visto desde agosto Ildebrando Antoniutti dos campañas contra la España de Franco: la desencadenada por la repatriación de los niños y la denuncia de abusos cometidos contra los prisioneros de guerra. Nadie puede decir que la situación se normaliza tras una victoria. Hay muchas cosas que no funcionan y se escapan al control de las autoridades. Hubo represalias contra los prisioneros y venganzas. La ofensiva de Santander causó 65000 presos. En Bilbao había 5276.

De esos 65000, fueron enviados a sus casas unos 40000. Otros 2000 quedaron detenidos en campos de concentración y eran liberados en cuanto se comprobaba que no existían delitos contra ciudadanos privados, es decir, cometidos fuera de las líneas de batalla.

El auditor de guerra de Bilbao le respondió lo mismo que esos días le transmitió el cardenal Goma. Había entonces dos curas condenados a muerte, cuya ejecución fue aplazada.

Antoniutti señala que sólo se han tomado severas medidas contra unidades comunistas, como el batallón «Malatesta». Su historia estaba llena de horrores. Se dijo que todos sus integrantes serían condenados a muerte. Muchos se reconciliaban con la Iglesia antes de la ejecución. Reconocían haber sido víctimas de la propaganda.

El 18 de septiembre Franco propuso un canje de 2500 hombres, entre 18 y 45 años, que desearan reintegrarse con sus familias, en la zona roja, por otros

189 Copia informe sobre la labor de Holman Gregory, Theobald Mathew y Riohad R. Ludlow, 26 octubre de 1937. Arthur Hinsley, arzobispo de Westminster, sin fecha, avalando la labor hecha por el P. Gábana ASV Nunz.Madrid 975 477-484. Una extensa información, «Bilbao Parents demand return of Children», Catholic Herald August 20, 1937, 1. Se presentó esta cifra para el dictamen de la comisión de abogados, copia ASV Nunz.Madrid 876 4-5.

190 Gomá-Antoniutti, Pamplona 2 octubre 1937, ASV Nunz.Madrid, 968 III 272. Notas con las noticias, ibidem. 270-271, y $A G$ 8, 23-24.

Hispania Sacra, LXI

124, julio-diciembre 2009, 691-753, ISSN: 0018-215-X 
tantos refugiados en las representaciones diplomáticas de Madrid. Había que esperar la respuesta ${ }^{191}$.

El día de la Virgen del Rosario, efeméride de la victoria de Lepanto 7 octubre 1571, Hildebrando Antoniutti presentó en Burgos a José Antonio de Sangróniz sus Cartas de Gabinete que lo acreditaban como encargado de negocios de la Santa Sede. Los soldados de la nueva España combatían ahora como cruzados en defensa de los mismos ideales: la civilización católica, dijo Sangróniz ${ }^{192}$.

Franco lo recibió en audiencia. Se sentía especialmente satisfecho de poder hablar con personas que abiertamente se profesan católicos. El primer asunto fue el clero vasco. Antoniutti creía que, tras la confusión de política y el apasionamiento, se reestablecería la normalidad, sobre todo, con la guía de un buen obispo. El administrador apostólico, Javier Lauzurica, había dado unas normas claras restableciendo la disciplina eclesiástica. Era preciso que el Estado lo apoyase y evitara la sensación de una injerencia indebida en la vida eclesiásti$\mathrm{ca}^{193}$. Esa observación le permitió denunciar ante Franco que el Auditor de Guerra de Bilbao le había dicho que, no habiendo un concordato entre España y la Santa Sede, estaba jurídicamente desligado de atenerse a las normas canónicas sobre procesamiento de clérigos y podía condenar a los sacerdotes vascos imputados, incluso a la pena de muerte.

Aprovechó la ocasión para conseguir medidas de gracia a favor de los curas vascos presos. Franco le dio estas seguridades: el obispo Lauzurica tendrá plena libertad para tratar con esos sacerdotes y proponer un arreglo. Serán revisados sus procesos. Ninguna sentencia de muerte se ejecutará. Se reducirán las penas o serán condonadas. Los condenados hasta seis meses serán puestos en libertad. Se permitirá poco a poco el regreso de los exiliados.

Hablaron de los seminarios y de la urgencia de que estos se abrieran de nuevo, de la educación de la juventud en un sentido «integralmente católico». Se había entregado a Javier Lauzurica un edificio para que reabriera el seminario. Pidió que se facilitara a los demás obispos lo mismo, dada la importancia de la formación de los futuros sacerdotes. Hablaron también de la enseñanza religio-

191 Ildebrando Antoniutti-cardenal Pacelli, 18 septiembre 1937, ASV Nunz.Madrid 974 III 276279.

192 Ese mismo día escribió a todos los obispos, presentándose como encargado de negocios. $A G 8$, 59-60. El cardenal Gomá le agradeció el elogio a su labor como representante oficioso de la Santa Sede, 13 octubre, ibidem. 103. Al día siguiente le escribió el cardenal Pacelli lo hizo en nombre de Pío XI, ibidem 112-113.

193 «...sarei tanto felice se, in una occasione si fausta e tanto sentita da lui (Franco) e dal popolo spagnuolo, all'inizio ella mia missione, avrei potuto riferire al Santo Padre buone notizie su trattamento dei sacerdoti baschi detenuti». 
sa en las escuelas. Franco dijo que esa materia se entregará al estudio de la autoridad eclesiástica y tendrá una orientación «integralmente católica»194.

Relacionado con esto, Franco se refirió a la Falange. Había entrado en ella gente poco fiable. Los estatutos que acababa de darles aseguraban que la Falange se inspirará en los principios católicos. Confidencialmente dijo a Antoniutti que había sido suya la iniciativa del cambio del embajador alemán, Wilhem Theodor Faupel, muy activo e influyente, sobre todo entre los falangistas. Por lo demás, ciertas manifestaciones de simpatía eran de justicia, dada la importante ayuda que Alemania prestaba a la España nacional ${ }^{195}$. No consintió que se introdujeran métodos de esterilización ${ }^{196}$.

Se interesó Antoniutti también por algunos prisioneros del ejército vasco ${ }^{197}$. Había gestiones ante la Santa Sede para saber de ellos. Franco le respondió: solo quedarán en prisión los que estuvieran procesados por delitos, pero no los soldados movilizados. En esos momentos no funcionaban bien los canjes con la zona roja. Los de sacerdotes se limitaban a los no refugiados en embajadas, porque los otros gozaban de la protección de un gobierno extranjero. El problema de los niños expatriados había que estudiarlo jurídicamente para ver si era posible una reclamación a los Estados que los retienen contra la voluntad de sus padres. Agradeció a la Santa Sede su acción humanitaria ${ }^{198}$. La conversación duró más de una hora.

El cardenal Gomá transmitía esos días noticias que avalaban su convicción de que la Santa Sede no se entendería con «la España cristiana», contraria al movimiento nacional o disidente dentro de él. Había que proseguir la información iniciada en la Carta Colectiva, porque no era fácil descubrir la verdad «en los complejísimo asuntos que se agitan alrededor de nuestra guerra»199.

${ }^{194}$ Las bases acordadas con Isidro Gomá para el restablecimiento de las cátedras de religión en los Institutos de Bachillerato, cardenal Gomá-cardenal Pacelli, Pamplona 4 octubre, AG 8, 45-46. La orden de la Presidencia de la Junta Técnica sobre la Enseñanza de de Religión en los Institutos Nacionales, 7 octubre, la envió el cardenal Gomá a Cardenal Pacelli, el 12 de octubre, ibidem 86-88. la respuesta del cardenal Pacelli, 31 octubre, ibidem 237.

195 Ángel ViÑAs, La España nazi y el 18 de julio, 2ª edición, Madrid, Alianza Editorial 1977. Walter L. BERNECKER, «La intervención alemana en la guerra civil española», Espacio, Tiempo y Forma, serie V Historia Contemporánea tomo V (1992) 77-104. Centrado en la dimensión cultural, Jesús de la HeRA MARTínez, La política cultural de Alemania en España en el período de entreguerras, Madrid, CSIC, 2002. Para este período 337-431.

196 49/37 Hildebrando Antoniutti-cardenal Pacelli, San Sebastián 25 noviembre 1937, ASV Nunz.Madrid 968 563-569, editado en Vicente CÁRCEL ORTí, «La nunciatura de Madrid y la embajada de España...» 334-337. Esta referencia en 335.

197 Hubo una gestión del cardenal Gomá, de la que informó a Ildebrando Antoniutti el 8 de septiembre. $A G 7,383$.

198 37/37 Ildebrando Antoniutti-cardenal Pacelli, 9 octubre 1937, ASV Nunz.Madrid III 968 226237, editado en Vicente CÁRCEL ORTí, «La nunciatura de Madrid y la embajada de España...» 322-334.

199 Cardenal Gomá-cardenal Pacelli, Pamplona 27 septiembre, AG 7, 576-577.

Hispania Sacra, LXI

124, julio-diciembre 2009, 691-753, ISSN: 0018-215-X 


\section{EL PAPA Y SU OBRA POR LA PAZ «A FAVOR DE TODOS LOS QUE SUFREN»}

En el otoño de 1937 la situación internacional alarmante. El delegado apostólico en Washington envió una cifra al cardenal Pacelli. Roosewelt había comido el 5 de octubre con el cardenal Mundelein, arzobispo de Chicago. Estados Unidos estaba dispuesto a trabajar por la paz. Le preguntó al cardenal si la Santa Sede podría asociarse. Deseaba que un enviado especial suyo fuera al Vaticano. Mundelein le dijo que lo hiciera para abrir los preliminares, Roosewelt excluyó la intervención, pero juzgaba necesario con el aislamiento a las naciones responsables de una agresión. Hablaba de dos guerras no declaradas: la de España y la de China, invadida por Japón. Quería ver en Washington al delegado apostólico 200.

El conde della Torre, director de L'Osservatore Romano, de visita en París, fue recibido por el subsecretario de Exteriores el 22 de diciembre. La situación internacional era grave. Italia había abandonado la Sociedad de Naciones. Creía que en todo el mundo, no solo en Francia, se miraba hacia la Santa Sede por su condición, que la ponía por encima de las naciones neutrales. Era una fuerza espiritual, moral, social y hasta política, fuera de sospecha. Por eso su actuación era claramente desinteresada, limpia.

Citó el conde della Torre a la URSS y a Alemania. No eran tan benévolas con la Santa Sede. Esta tenía la experiencia de que iniciativas suyas, inspiradas en el deseo de contribuir a la paz, fueron luego criticadas y no resultaron eficaces. Pasó en tiempos de Benedicto XV. La respuesta fue: ahora las cosas han cambiado mucho. Incluso la URSS no rechazaría la intervención pacificadora del Papa. Los países que no estaban en la Sociedad de Naciones podrían aceptar una propuesta que no venía de ella.

Estaba convencido el director de L'Osservatore Romano que esta conversación no era del todo privada. Posiblemente se consideró un medio seguro para hacer llegar al Vaticano una idea que el gobierno francés aprobaba. Pudo recoger en París una opinión unánime sobre la oportunidad y la necesidad de que la Santa Sede lo intentara: había que reanudar lazos rotos y hacer un intento, quizás supremo, para un arreglo, que rectificara el empeoramiento de la situación internacional. Pío XI debería, según las personas con las que habló della Torre, publicar un documento continuando así «sus preocupaciones de padre a favor de todos los que sufren».

Volvió a insistir el 4 de enero. Francia e Inglaterra estaban poniendo calma y no querían responder a la campaña agresiva de la prensa italiana. De París trajo

200 «...mi limiterò sentire suo proietto per riferirne Santa Sede». Tc 173 Amleto Cicognani, 12 octubre 1937, ASV Segr.Stato Affari Eclesiastici Stati Ecclesiastici IV fasc 571 pos. 54763 . El 15 de octubre el ministro de Asuntos Exteriores citó al nuncio en París, ibidem 64. 
la impresión de que sus colegas periodistas estaban convencidos de que el eje Roma-Berlín estaba preparando una guerra. La gente estaba asustada por los sucesos en el Extremo Oriente, China, España, y por el interés de Alemania e Italia en favorecer los enemigos de Francia y del el Reino Unido en Palestina. Se temía una guerra.

¿Cómo estaban las cosas? Francia había perdido a su antigua aliada, Rusia. No estaba bien visto tener amistad con la URSS. Su conducta en China y otros síntomas parecían confirmar que los soviéticos no deseaban entrar en conflictos armados. Su situación interna la empujaba al pacifismo. ¿Cómo podría Francia reforzar un frente oriental? Yvon Delbos lo buscó durante su visita a los países del Este de Europa. En Polonia, había buena disposición a una alianza entre ellas, pero era un problema la actitud de Checoslovaquia hacia sus minorías. Un cambio radical en este punto era una condición innegociable para que esa idea saliera. El Presidente Edvard Beneš estaba de acuerdo, pero nada podía hacer ante la hegemonía de los checos, intransigentes en este tema.

En Bucarest nada consiguió Delbos. Había elecciones. Podría producirse un cambio en la política interna de Rumanía y en sus relaciones internacionales.

Un problema serio era la propaganda nacionalista. En Belgrado, comprobó la debilidad del Regente y del Gobierno ante la opinión, mientras crecía la fuerza de la oposición.

El balance era que no existía sustituto en el Este a la alianza que Francia tuvo con Rusia. Se creía posible la paz con Alemania, pero no con Italia ${ }^{201}$.

Todo parecía dar credibilidad a la posición de De Tessent, subsecretario de Asuntos Exteriores ${ }^{202}$. Varios políticos visitaron al cardenal Verdier, arzobispo de Paris. Estaban convencidos de que Italia iría a una guerra con Francia. Invadiría Túnez. La fecha, la próxima primavera. Italia iría por delante y detrás de ella, Alemania. Aún era posible frenar ese movimiento, que terminaría en una guerra europea, si Mussolini no apagaba la propaganda contra Francia en Argelia y Túnez y en otros lugares ${ }^{203}$.

En Ginebra Delbos aseguró a Paul Henri Spaak, su colega belga: habrá guerra en marzo entre Francia e Italia, que invadirá Túnez. Convocados en Bruselas, varios diplomáticos belgas dijeron que se trataba de una maniobra de Delbos para evitar que Bélgica reconociera la conquista italiana de Etiopía en

\footnotetext{
${ }^{201}$ Las relaciones difíciles entre Roma y París, 4048 Valeri-cardenal Pacelli, 29 enero, ibidem 83-89.

202 G. della Torre-Pacelli, 29 diciembre 1937 y 4 enero 1938, ibidem. 67-67bis y 71-72. Las noticias del Conde della Torre las confirma el nuncio. 3959 Valeri-cardenal Pacelli, 20 enero 1938, ibidem 77-78. El ambiente en que se reúne esos días la Sociedad de Naciones, 3440 y 3470 Bernardini-cardenal Pacelli, 24 y 30 enero 1938, ibidem 74-75 y 92-93.

2033991 Valeri-cardenal Pacelli, 25 enero, ibidem 9-91.
}

Hispania Sacra, LXI

124, julio-diciembre 2009, 691-753, ISSN: 0018-215-X 
octubre de 1935. Había un rearme de Inglaterra y de Italia. Ese equilibrio creado por el temor mutuo disuadía a quienes desearan una guerra ${ }^{204}$. Pero en el Vaticano, a la vista de todos estos datos, concluyeron en marzo de 1938 que no esta próxima la guerra ${ }^{205}$.

Tras La unificación de las milicias del bando nacional en FET y de las JONS y a la vista de las decisiones de las autoridades, el cardenal Gomá sintió malestar y desconfianza ante las actitudes totalitarias. Nada de eso cuadraba con la necesaria libertad de la Iglesia en la educación, la libertad de las asociaciones católicas y de las obras sociales católicas. La imposición de un sindicato único acababa con los sindicatos libres y confesionales bajo influencia de los católicos sociales 206 .

La Santa Sede siguió atentamente la presión de la Alemania nazi sobre Franco. Comprendía las razones políticas que podían explicar esas manifestaciones de simpatía entre los nacionales, pero avisaba a Ildebrando Antoniutti que estuviera atento a las consecuencias de la ideología racista, sobre todo entre los jóvenes. Le pedía el cardenal Pacelli que llamara la atención de las autoridades eclesiásticas y civiles sobre este punto. Lo hizo en la audiencia con Franco la primera semana de octubre. Había pedido este que fuera trasladado el embajador alemán, al que juzgaba enemigo del catolicismo ${ }^{207}$.

El 2 de noviembre de 1937 Antoniutti fue recibido en audiencia privada por Franco en Burgos. Hablaron primero de la influencia nazi en la España nacional. Luego de algunos problemas que la censura planteaba a los obispos: unas veces se dejaba pasar cosas ofensivas a la Iglesia y otras se prohibían textos ortodoxos.

Presentó Antoniutti una lista de curas vascos exiliados. El arzobispo de Westminster, el de Malinas y otros obispos franceses daban buenos informes. Su retorno mejoraría la imagen de los nacionales. Los no implicados en la rebe-

2043654 Benardini-cardenal Pacelli, 24 febrero 1938, ASV Affari. Eclesiastici Stati Ecclesiastici IV fasc 572 pos. 5472.

205 Nota manuscrita, papel timbrado Segreteria di Stato, 14 marzo 1938, ibidem 4-5. Puede concluirse de una nota sobre la conversación con el embajador de Francia ante la Santa Sede.

206 Vicente Cárcel OrTí, Pío XI entre la República y Franco... 264-265. Vid. la introducción a Archivo Gomá. Documentos de la Guerra Civil. 8 octubre 1937, edición de José Andrés-Gallego y Antón, M. Pazos, Madrid, CSIC, 2003, 10. Gomá, en su carta al cardenal Pacelli del 7 de abril de 1937 habló de la guerra como esta «desgraciada contienda».

207 3774/37 Pacelli-Antoniutti, 23 septiembre 1937, ASV Nunz.Madrid 968 VI 549. La puesta en marcha de este instrucción y la insistencia en la labor de la Acción Católica y de la prensa católica local, 38/37 Burgos 11 octubre 1937, ibidem. 557-559. El embajador de Franco en Berlín, había manifestado que el catolicismo estaba aliado con los judíos, había fracasado históricamente y era necesario acabar con la acción política de los católicos... Nota anexa 4683/37 Pacelli-Antoniutti, 18 noviembre, ibidem. 560 y 556 . 
lión y los que no hicieron propaganda contra la España nacional, podrían volver sin peligro alguno.

Las tropas nacionales habían demostrado en la campaña de Asturias su eficacia. ¿Qué pensaba del retiro de los voluntarios extranjeros? Franco no parecía oponerse, pero pedía una garantía a Francia: que dejara de ayudar a la España roja. Aviones franceses habían causado grandes daños en Pamplona, una ciudad abierta, y en otras localidades indefensas.

Tras la conquista de Santander, Franco ordenó que las fuerzas italianas del Corpo Volontario Italiano se retiraran y no participaran en la campaña de Asturias.

Franco agradecía al Papa su ayuda en la repatriación de los niños vascos ${ }^{208}$.

Hubo una nueva entrevista el 22 de noviembre. Hablaron de la preocupación de la Santa Sede por la propaganda nazi. Antoniutti informó que los obispos estaban preocupados por el contagio en miembros de la Falange. Recordó el «insolente discurso» de Goebbels en Nürenberg el año anterior, denunciando que la Iglesia era responsable de la difusión del comunismo en España, porque no era capaz de combatirlo. Entregóa Franco la encíclica Mit Brennender Sorge, señalando la conveniencia de que fuera conocida en España.

Franco dijo esa propaganda no tendría arraigo, pues había una oposición la civilización, la española y la alemana. Tenían dos programas opuestos, El nacional-socialista era pagano, el suyo, católico. Había tomado ya medidas para evitar esa posibilidad y ese peligro. Recordó que había logrado la retirada de von Feipel y el retorno de los médicos alemanes que querían introducir prácticas de esterilización.

Tuvo que consentir los viajes de jóvenes falangistas a Alemania, porque no veía peligro en ello y como un gesto político. Alemania era una aliada y su ayuda era muy importante.

La Santa Sede siguió temiendo la excesiva influencia nazi. Habló Antoniutti con Sangróniz el 13 de diciembre sobre las palabras del marqués de Magaz en Berlín. Las creyó este, porque era capaz de esas afirmaciones y de más, debido a su rencor hacia la Santa Sede. Era injusto, porque el fracaso de su gestión fue culpa suya, no del Vaticano.

Antoniutti subrayó la crítica que desde la Falange se hacía a la Iglesia, las acusaciones contra los católicos, la demanda de que la diplomacia de la Santa Sede se fundara en la «buena fe». Eso es lo que faltaba a la delegación nacional de propaganda, que había silenciado la labor humanitaria del Papa y no cesaba

208 49/37 Hildebrando Antoniutti-cardenal Pacelli, San Sebastió n 25 noviembre 1937, ASV Nunz.Madrid 968 563-569, editado en Vicente CÁRCEL ORTí, «La nunciatura de Madrid y la embajada de España...» 334-337.

Hispania Sacra, LXI

124, julio-diciembre 2009, 691-753, ISSN: 0018-215-X 
de hablar elogiosamente de Alemania. Había calificado la alocución del Papa a los refugiados españoles en Roma como «palabras de hielo». Sangróniz dijo que el director nacional de prensa era el sacerdote, Fermín Yzurdiaga, pero ocupaba ese puesto sin autorización de la jerarquía, contra el criterio del cardenal Gomá y del obispo de Pamplona ${ }^{209}$. Pidió a Sangróniz que informara de esto a Franco 210

Ante la demanda de que la Santa Sede exigiera la renuncia de Vidal i Barraquer, acusado de connivencia con los vascos que estaban fuera de España, Antoniutti respondió con las mismas palabras que Sangróniz: esperemos que acabe la guerra.

Esos días Antoniutti había hecho llegar ejemplares de la encíclica contra el nazismo a varios obispos españoles, para que la distribuyeran a las autoridades civiles $^{211}$.

\section{ENTRE LA COMPASIÓN Y LA VICTORIA}

Más que conclusiones, queremos concluir con algunos hechos que revelan cuál era la situación y qué expectativas había al acabar 1937.

En la Navidad había 400 condenados a muerte en Bilbao. El 14 de noviembre fueron ejecutados 44 . El día anterior, otros muchos. ¿Podría hacerse algo? Había una iniciativa de Juan Aldazábal para promover la reconciliación en esas fechas. El jesuita Remigio Vilariño lo presentó al delegado apostólico. No se trataba de discutir la justicia de las sentencias, sino de pedir medidas de gracias para quienes no tenían delitos de de sangre y solo estaban acusados de rebelión. Se les podría exigir una retractación, incluso, por juramento, y una declaración de que abandonaban sus ideas separatistas. Se podría cambiar su condena por

${ }^{209}$ El obispo de Pamplona, Marcelino Olaechea, y el cardenal Gomá pidieron a Franco que lo relevara del cargo. No lo hizo y además lo nombro Consejero Nacional. Gomá-Antoniutti, Toledo, 27 octubre, $A G$ 8, 199. Sobre este tema, Ildebrando Antoniutti-Marcelino Olaechea, San Sebastián 17 enero 1938, ibidem 9, 119-120. Comentario del cardenal Gomá sobre la afición excesiva de algunos clérigos a intervenir en la política y el mal ejemplo que suponía este caso, Gomá-Antoniutti, 19 enero, ibidem 123-123.

${ }^{210}$ Sabemos que Marcelino Olaechea y el mismo Isidro Gomá protestaron ante Franco por el nombramiento para ese cargo. No se hizo caso de la protesta. Yzurdiaga fue nombrado para el Consejo Nacional. Eran lamentables el fondo y la forma en esta medida. Isidro Gomá-Ildebrando Antoniutti, Toledo 27 octubre 1937, ASV Nunz.Madrid 970 I 36. Hablaron en una entrevista entre ambos el 3 de febrero de 1938. Había un hecho evidente de desacato a la autoridad del obispo de Pamplona, «Nota conversación Delegado Pontificio» 3 febrero 1938, ibidem 66.

211 4933/37 Pacelli-Antoniutti, 6 diciembre, respuesta de Ildebrando Antoniutti, 16 diciembre, ibidem 570 y $572-579$. 
otras penas, incluso por multas. Muchos condenados eran buenos ciudadanos. Había escrito el P. Vilariño al obispo de Pamplona, pero había enviado la carta, porque tenía que pasar por la censura ${ }^{212}$.

El Cardenal Segura, el mismo día de su entrada como arzobispo de Sevilla, publicó «La paz de Cristo». Es su primera pastoral. Las victorias, escribe, nos están demostrando la historia antigua y la moderna, han sido muchas veces «semillero de disturbios y de nuevas y más sangrientas luchas» 213 . En su felicitación de año nuevo, aparecida el 1 de enero de 1938, pidió «que no se malogren en la victoria los inmensos sacrificios de todos los órdenes que ahora se están llevando a cabo por todos los buenos hijos de la Patria» ${ }^{214}$. ¿Los malograrían la reconciliación y el perdón o la imposición y la intransigencia? La España posible ${ }^{215}$ ha de ser un argumento en ese entramado de la razón de la esperanza, que une memoria y proyecto, que hace del mañana incierto una jornada, que como aquellas del origen pueda acabar en la satisfacción de haber hecho una obra «buena» 216 .

En noviembre de 1937 la Santa Sede hizo una gestión a favor de Joaquín Maurín. El diputado por Barcelona, director de Adelante y de La Batalla estaba preso en Zaragoza. El cardenal Pacelli sabía que no había participado en los sucesos de julio en Barcelona, pues estaba en la zona controlada por los nacionales. Fijó esta norma de conducta: «Benchè poi il medesimo Signore abbia sovente combattuto ne suoi scritti la Chiesa Cattolica, non mi sembra che ciò sia motivo sufficiente per astenersi dal compiere un atto di carità». Antoniutti se interesó por Maurín. Se informó del trato recibido por él. Le aseguraron que tendrían presente la recomendación hecha por el cardenal Pacelli217.

El 18 de diciembre, Juan de Ajuriaguerra escribió a Antoniutti. Habían sido ejecutados en la Cárcel de Larrinaga (Bilbao) 128 oficiales del ejército de Euzkadi. Estaban con el «ejecútese» más de doscientas sentencias a muerte. Se tra-

212 Remigio Vilariño-Ildebrando Antoniutti, 15 y 21 noviembre 1937, ASV nm 974 III 318-318.

${ }^{213}$ Francisco Gil Delgado, Pedro Segura. Un cardenal de fronteras, Madrid, Biblioteca de Autores Cristianos, 2001, 313.

${ }^{214}$ Santiago MARTínez SÁncheZ, Los papeles perdidos del cardenal Segura ... 428.

215 Esta expresión la usó Julián Marías para comprender un momento histórico de cambio y resistencias al cambio, La España posible en tiempo de Carlos III, Madrid, Sociedad de Estudios y Publicaciones, Madrid, 1963.

${ }^{216}$ Este verano la Universidad Rey Juan Carlos ha vuelto organizado un curso sobre «La Otra España Posible». Esta es la hipótesis: los españoles han acreditado estos últimos años su «predisposición hacia el consenso y el entendimiento, al menos en las cuestiones fundamentales y básicas, sabiendo que los grandes avances sociales, culturales, económicos y políticos de España, se han dado más cuando hemos trabajado unidos bajo el consenso, la generosidad y el interés general, que cuando lamentablemente hemos buscado el enfrentamiento y la exclusión del otro».

217 4682/37 Pacelli-Antoniutti, 18 noviembre 1937 y 27 enero 1938, ASV Nunz.Madrid 974348 y 427. Condenado a 30 años en 1944, Maurín fue indultado en 1946.

Hispania Sacra, LXI

124, julio-diciembre 2009, 691-753, ISSN: 0018-215-X 
taba de jóvenes católicos, de personas honradas, de gran formación cristiana. Eran los mejores feligreses de cada pueblo. Pedía que la Santa Sede interpusiera su solicitud de indulto ${ }^{218}$. Semanas más tarde, Santa Sede hizo una gestión a favor de Juan de Ajuriaguerra. Estaba incluido en una lista para canje ${ }^{219}$.

El 13 de noviembre de 1937 regresó Azaña a Madrid. Pronunció un discurso. La guerra no había sido una pesadilla. Era una realidad. Hubo un invasor que pilló a la República sin tropas, sin armas, sin Estado, sin medios para gobernar, combatiendo con una mano y con la otra fabricando armas. El 17 de julio se derrumbó el Estado. Hubo bastantes cabezas para reconstruirlo. Lo más urgente fue la formación de un ejército. Hoy defensor de España, será mañana el defensor y sostén de su prestigio ante el mundo. No había muchas formas de hacer un ejército, sino una. No queda más camino que el iniciado ya: un ejército y un Gobierno, que encuentre el apoyo de todos los republicanos para restablecer la paz. Todo debe subordinarse a ganar la guerra.»Cuando hablan las armas, todo el mundo calla»220.

Hace algunos años una canción popularizó los versos de Brecht. Hubo entonces una pasión ética, fugaz, pero movilizadora. Nadie pidió entonces revancha. El pueblo llano estaba entre los vencidos y entre los vencedores. Entre unos y otros, el pueblo llano, el pueblo de la tierra, los que viven siempre abajo, era el vencido, el «vell vençut», de Salvador Espriu, por cuya dignidad la gente se puso en pie, como la multitud, en otros versos de César Vallejo, a fin de que la muerte no saliera victoriosa sobre ninguno de los amenazados por ella. La paz no nace de la guerra. La paz no la sostienen ejércitos ni Estados. «La obra de la justicia será la paz, dice el viejo profeta, y el fruto de la justicia, la tranquilidad y la seguridad para siempre» (Is 32,17$)^{221}$. La reciben y la guardan los que se reconcilian para que la justicia y la paz se besen (Salmo 85).

218 Juan de Ajuriaguerra-Ildebrando Antoniutti, Larrinaga, 28 diciembre 1937, ibidem 369. Mal colocada, debería ser 269.

219168339 Pacelli-Antoniutti, 5 abril 1938, ASV Nunz.Madrid 974 597-600. Se pedía una medida de gracia con motivo del viernes santo. Antoniutti-Pacelli, 26 marzo, ibidem 617-618.

220 Manuel AzAÑA, «Discurso en el Ayuntamiento de Madrid, 13 noviembre 1937», Antología. Discursos 2, selección, prólogo y notas de Federico Jiménez Losantos Madrid, Alianza Editorial 1983, 256-258. Sobre el papel decisivo de la intervención extranjera en la prolongación de la guerra, «Discurso en el Ayuntamiento de Barcelona», 18 de julio de 1938, ibidem 274.

221 «Opus iustitiae, pax» será el lema que el cardenal Pacelli elegirá tras ser elegido sucesor de Pío XI. 